'Monarchs and Hydrarchs is an original and potentially important piece of work, which challenges widely accepted particularist interpretations of Viking activity in northern continental Europe, and rather seeks a coherent and dynamic understanding of the phenomenon. In applying the concept of "hydrarchy" to the analysis of a range of sources (both well-known and under-researched), the study provides not only new data, but a new theoretical framework for their interpretation. Elegantly written and impressive in its interdisciplinary scope, this volume should be of significant interest to early medieval historians, archaeologists, and other scholars with or without previous knowledge of Scandinavian activity on the Continent'.

Steven Ashby, Senior Lecturer in Archaeology, University of York, UK

'This book is an essential read for anyone engaging on research on the Viking Age in Francia. In Monarchs and Hydrarchs, Cooijmans has combined detailed analysis of viking activity and politics with the application of abstract conceptual models to identify overarching patterns of behaviour. One of the great strengths of the book is Cooijmans's ability to draw on sources in a variety of languages and from different disciplines to develop an original and overarching survey of this field'.

Clare Downham, Reader in Irish Studies, University of Liverpool, UK

'The contacts between the Scandinavian world and the Frankish realm of Charlemagne and beyond have been commonly viewed through the lens of near-contemporary sources of variable bias, limited onomastic elements, and even fewer archaeological finds. An awareness of the incursions along the major waterways underpins our basic knowledge of the region. These rivers, selected as case study regions (Loire, Seine, and the Lower Rhine-MeuseScheldt basin) are viewed here by Cooijmans as "representing expansive corridors of waterborne commerce and communication" and, crucially, the points of convergence of mariners from various origins - not only those from the northern neighbours. However, in exploring and indeed characterising the so-called hydrarchy established through targeted contact (up to the 840s CE) and intensive activity (840s-930s CE) in the region, Monarchs and Hydrarchs enables insight into changes from passing contact to permanent settlement in Francia.

'Through the development of a temporal model, where the contact is subdivided into four distinct elements, commencing before the death of Charlemagne in 814 and progressing in intensity into the 930s, the author critically assesses the sources and demonstrates a clarity in the expedient decision-making of the vikings, based on "exchanges of intelligence, cumulative experience, and the collective need for socioeconomic subsistence and enrichment". These words are the author's, succinctly phrased and economically expressed, a true feature of the writing style of this volume. Through the detailed 
examination of the written sources in combination with a critical assessment of earlier scholarship, this author makes full use of the views of earlier scholars building upon their strengths rather than fashionably demolishing all that has been written before. This is a valuable and major contribution to scholarship which will be well-cited for many years to come'.

Colleen Batey, Senior Lecturer in Archaeology, University of Glasgow, UK 


\section{Monarchs and Hydrarchs}

As the politico-economic exploits of vikings in and around the Frankish realm remain, to a considerable extent, obscured by the constraints of a fragmentary and biased corpus of (near-)contemporary evidence, this volume approaches the available interdisciplinary data on a cumulative and conceptual level, allowing overall spatiotemporal patterns of viking activity to be detected and defined and thereby challenging the notion that these movements were capricious, haphazard, and gratuitous in character.

Set against a backdrop of continuous commerce and knowledge exchange, this overarching survey demonstrates the existence of a relatively uniform, sequential framework of wealth extraction, encampment, and political engagement, within which Scandinavian fleets operated as adaptable, ambulant polities - or 'hydrarchies'. By delineating and visualising this framework, a four-phased conceptual development model of hydrarchic conduct and consequence is established, whose validity is substantiated by its application to a number of distinct regional case studies. The parameters of this abstract model affirm that Scandinavian movements across Francia were the result of prudent and expedient decision-making processes, contingent on exchanged intelligence, cumulative experience, and the ongoing individual and collective need for socioeconomic subsistence and enrichment.

Monarchs and Hydrarchs will appeal to both students and specialists of the Viking Age, whilst serving as an equally valuable resource to those investigating early medieval Francia, Scandinavia, and the North Sea world as a whole.

Christian Cooijmans is a British Academy Research Fellow at the University of Liverpool, UK. Having obtained his doctorate from the University of Edinburgh, his research focusses on the reach and repercussions of viking endeavour across mainland Europe, as well as its ensuing, premodern historiography. 


\section{Routledge Archaeologies of the Viking World}

\section{Viking Silver, Hoards and Containers}

The Archaeological and Historical Context of Viking-Age Silver Coin Deposits in the Baltic c. $800-1050$

Jacek Gruszczyński

\section{Monarchs and Hydrarchs}

The Conceptual Development of Viking Activity across the Frankish Realm (c. 750-940)

Christian Cooijmans

For more information about this series, please visit: www.routledge.com/ Routledge-Archaeologies-of-the-Viking-World/book-series/RAVW 


\section{Monarchs and Hydrarchs}

The Conceptual Development of Viking Activity across the Frankish Realm (c. 750-940)

\section{Christian Cooijmans}

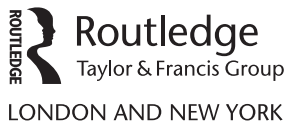


First published 2020

by Routledge

2 Park Square, Milton Park, Abingdon, Oxon OX14 4RN

and by Routledge

52 Vanderbilt Avenue, New York, NY 10017

Routledge is an imprint of the Taylor \& Francis Group, an informa business

(C) 2020 Christian Cooijmans

The right of Christian Cooijmans to be identified as author of this work has been asserted by him in accordance with sections 77 and 78 of the Copyright, Designs and Patents Act 1988.

All rights reserved. No part of this book may be reprinted or reproduced or utilised in any form or by any electronic, mechanical, or other means, now known or hereafter invented, including photocopying and recording, or in any information storage or retrieval system, without permission in writing from the publishers.

Trademark notice: Product or corporate names may be trademarks or registered trademarks, and are used only for identification and explanation without intent to infringe.

British Library Cataloguing-in-Publication Data

A catalogue record for this book is available from the British Library.

Library of Congress Cataloging-in-Publication Data

A catalog record has been requested for this book.

ISBN: 978-0-367-20214-9 (hbk)

ISBN: 978-0-429-26020-9 (ebk)

Typeset in Bembo Std

by Newgen Publishing UK 
Incepisse aliquid iam pars est quantula facti.

'To have begun something is already a part, however small, of completing it.'

Heiric, Monk of Auxerre (c. 865)

Vita sancti Germani episcopi Antissiodorensis

Si tanta facilitate discuti possent a quoquam quanta moventur quaestiones, olim ad consummatam studiosi quique sapientiam evasissent.

'If questions could be answered by anyone as easily as they are raised, all scholars would have reached the summit of wisdom long ago.'

Lupus Servatus, Monk of Ferrières (837)

Epistolae 



\section{Contents}

List of figures $\quad$ xii

List of tables xiv

Acknowledgements $\quad \mathrm{xV}$

List of abbreviations $\quad \mathrm{xvi}$

I Introduction 1

I.1 The story so far 2

I. 2 Modelling viking activity in Francia 3

I.3 Primary sources 9

I. 4 Terminology and definitions 10

$\begin{array}{ll}\text { II The Scandinavian perspective } & 17\end{array}$

II. 1 Governance 18

II.1.1 Centralisation of power 18

II.1.2 Kings of the early Viking Age (c. 770-950) 22

II.1.3 Monarchs and hydrarchs 31

II. 2 Domestic economies (up to c. 950) 35

II.2.1 Towards the Viking Age 35

II.2.2 Silver fever 38

II.2.3 A network transformed 41

II.3 Conclusion: The Scandinavian perspective 43

III Carolingian Francia

III.1 Political landscape 57

III.1.1 Power and partition 57

III.1.2 Law and order 67

III. 2 Economic landscape 71

III.2.1 Wealth and production 71

III.2.2 Commerce and currency 73

III.3 Conclusion: Carolingian Francia 77 
IV Earliest Franco-Scandinavian contact (up to 814) 88

IV.1 The exchange of goods 88

IV.2 The exchange of knowledge 91

IV.3 Conclusion: Earliest Franco-Scandinavian contact 94

$\mathrm{V}$ Early viking encounters (up to 840)

V.1 Earliest incursion 100

V.1.1 Pre-Viking Age (up to c. 750) 100

V.1.2 Dawn of the Viking Age (c. 750-830s) 101

V.1.3 Targets and motivations 105

V.2 Early encampment 109

V.3 Early Carolingian countermeasures 110

V.4 Conclusion: Early viking encounters 112

VI Intensified viking activity (c. 840s-930s)

VI.1 Intensified incursion 120

VI.1.1 Size and frequency 120

VI.1.1.1 Mobility and logistics 123

VI.1.2 Targets and motivations 128

VI.1.2.1 Spatial and spatiotemporal development 131

VI.1.2.2 Expediency 132

VI.1.2.3 Correlation to Insular activity 135

VI.1.3 Personal and material damage 136

VI.2 Encampment 141

VI.2.1 Purpose 141

VI.2.1.1 Recuperation 141

VI.2.1.2 Protection and aggression 142

VI.2.1.3 Diversification 145

VI.2.2 Known and speculated locations 146

VI.2.2.1 Developmental patterns 150

VI.3 Carolingian countermeasures 151

VI.3.1 Operational countermeasures 152

VI.3.1.1 Military opposition 152

VI.3.1.2 Fortification 154

VI.3.2 Preventative countermeasures 159

VI.3.2.1 Evacuation 159

VI.3.2.2 Trade embargoes 160

VI.3.3 Remedial countermeasures 161

VI.3.3.1 Tribute payments 161

VI. 4 Political affiliation 165

VI.4.1 Armistice, alliance, and mercenarism 170

VI.4.2 Commendation 172

VI.4.2.1 Land grants 174

VI.4.2.2 Migration and settlement 177

VI.5 Ongoing Franco-Scandinavian commerce 179

VI. 6 Conclusion: Intensified viking activity 181 
VII Conceptual development model

VII.1 Assembling the model 209

VII.2 Validating the model 211

VII.2.1 Lower Rhine-Meuse-Scheldt basin 215

VII.2.2 Seine basin 218

VII.2.3 Loire basin 223

VII.3 Conclusion: Validity of the conceptual development model 226

VIII Concluding remarks and discussion

Bibliography

Index 


\section{Figures}

I.1 (a) James E. Vance's transmarine mercantile model 6

$\begin{array}{lll}\text { I.1 (b) Peter Rimmers's hybrid transport system } & 7\end{array}$

I.2 Carolingian Europe at its largest extent (c. 814) 8

II.1 The Fabech and Ringtved Model of southern Scandinavian
settlement hierarchy

II.2 Late Iron Age central places in southern Scandinavia 19

II.3 Proposed patrilineal pedigree of King Harald 25

II.4 Proposed extent of Danish sovereign influence (early ninth century) 26

II.5 Proposed patrilineal pedigree of King Horik I 29

II.6 Proposed patrilineal pedigree of King Gnupa 30

II.7 Major emporia mentioned in the text, c. $800 \quad 37$

II.8 Earliest medieval towns of Scandinavia, c. $1050 \quad 42$

II.9 KG 10a and KG 11 coinages 43

II.10 Southern Scandinavian component of the proposed

III.1 Diagram of Carolingian patrilineal descent (simplified) 59

III.2 Carolingian Europe at the death of Charlemagne (814) 60

III.3 Carolingian Europe following the Treaty of Verdun (843) 61

III.4 Carolingian Europe following Lothar's administrative
division of 855

III.5 Carolingian Europe following the Treaty of Meerssen (870) 65

III.6 Frankish component of the proposed spatial schematic 78

IV.1 Known locations of early Franco-Scandinavian envoys

IV.2 Phase I of the conceptual model's spatial schematic 96

V.1 Locations mentioned in the text (coastal Aquitaine) 102

V.2 Locations mentioned in the text (coastal Low Countries) 106

V.3 Phase II of the conceptual model's spatial schematic 114

VI.1 Incidence of viking incursions on Frankish soil in five major ninth-century narratives 124

VI.2 Abstract representation of hydrarchic military organisation 126 
VI.3 Spatiotemporal progression of hydrarchic incursions on upstream urban centres

VI.4 Abstract representation of upstream travel distances to urban centres subject to viking incursion

VI.5 Overall concentration of successful viking incursions across Francia (840-940)

VI.6 Recorded and suspected locations of Scandinavian encampment (840-940)

VI.7 Proposed extent of Rorik's benefice in Frisia (850s-70s) 176

VI.8 Phase III of the proposed spatial schematic 183

VI.9 Phase IV of the proposed spatial schematic

VII.1 Composite spatial schematic of the conceptual development model

VII.2 The Lower Rhine-Meuse-Scheldt basin

VII.3 The Seine basin

VII.4 The Loire basin 


\section{Tables}

IV.1 Recorded Franco-Scandinavian envoys (up to 814) 94

VI.1 Reported numbers of individuals and ships in regional viking encounters (840-940)

VI.2 Reported instances of vikings taking or holding captives (840-940) 139

VI.3 Documentary references to viking encampment (840-940) 147

VI.4 Documentary references to Frankish fortification in response to viking activity (840-940) 156

VI.5 Reported instances of tribute payments to vikings (840-940) 162

VI.6 Known hydrarchs active around the Frankish realm (840-940) 166

VI.7 Reported instances of hostages granted or received by Scandinavians, or mutually exchanged between Scandinavians and Franks (840-940) 170

VII.1 Composite sequential framework of the conceptual development model for Franco-Scandinavian interaction 


\section{Acknowledgements}

This study represents a labour of love, made possible only through the kind help and support of various colleagues and comrades.

A tremendous word of thanks is due, first of all, to Alan Macniven and Arne Kruse, without whose prudent and level-headed guidance this book would not have seen the light of day. Dialogue and discussion with numerous other colleagues and friends have helped to further refine some of the thoughts in this work, and I am particularly grateful to Steve Ashby, Manuel Fernández-Götz, Bill Aird, Guy Puzey, Thorsten Lemm, and Neil Price for all their assorted aid and advice. By much the same token, I am obliged to Charlotte Fabech, Jytte Ringtved, Elin Malmer, Bert Brouwenstijn, and Tiffany C. Vance for kindly granting me permission to reproduce a number of figures in this volume.

A special note of appreciation goes to Terry Barry, for first recognising and fostering my interest in the viking world during my time at Trinity College Dublin, many years ago.

Heartfelt gratitude is likewise owed to my parents and siblings, for continuing to support my intellectual endeavours and recurrent decisions to move overseas.

Lastly, but most importantly, I thank my wife, Laura, for indulging this foolish endeavour with unwavering patience, reason, and warm-heartedness. 


\section{Abbreviations}

$\begin{array}{ll}\text { AB } & \text { Annales Bertiniani (Annals of St. Bertin) } \\ \text { AC } & \text { Adonis Chronicon (Chronicle of Ado of Vienne) } \\ \text { AEng } & \text { Annales Engolismenses (Annals of Angoulême) } \\ \text { AF } & \text { Annales Fuldenses (Annals of Fulda) } \\ \text { AFL } & \text { Flodoardi annales (Annals of Flodoard of Rheims) } \\ \text { AFont } & \text { Annales Fontanellenses (Annals of Fontenelle) } \\ \text { AM } & \text { Angers Miscellany (MS 817) } \\ \text { ARF } & \text { Annales regni Francorum (Royal Frankish Annals) } \\ \text { ASC } & \text { Anglo-Saxon Chronicle } \\ \text { MS A } & \quad \text { Parker Manuscript } \\ \text { MS D } & \quad \text { Worcester Manuscript } \\ \text { MS E } & \quad \text { Peterborough Manuscript } \\ \text { MS F } & \quad \text { Domitian Bilingual } \\ \text { AV } & \text { Annales Vedastini (Annals of St.Vaast) } \\ \text { AX } & \text { Annales Xantenses (Annals of Xanten) } \\ \text { BPU } & \text { Abbonis bella Parisiacae urbis (Abbo's Wars of the Urbs of Paris) } \\ \text { C1-C24 } & \text { Charter evidence; see Bibliography for details. } \\ \text { CC } & \text { Capitulare Carisiacense (Capitulary of Quierzy, 877) } \\ \text { CCEp } & \text { Caroli calvi epistolae (Letters of Charles the Bald) } \\ \text { CM } & \text { Chronicon Moissiacense (Chronicle of Moissac) } \\ \text { CMS } & \text { Capitulare missorum Suessionense (Soissons Capitulary of the } \\ \text { CP } & \text { Missi, 853) } \\ \text { EA } & \text { Capitula Pistensia (Capitulary of Pitres, 862) } \\ \text { ECT } & \text { Epistola Adelermi (Letter of Adalelm of Troyes, 891) } \\ \text { ELH } & \text { Edictum Compendiense de tributo Nordmannico } \\ & \text { (Edict of Compiègne on the Tribute to the Northmen, 877) } \\ \text { EP } & \text { (Pascasii Radbertii expositio in lamentationes Hieremiae } \\ \text { ESC } & \text { Jeremiah) } \\ & \text { Edictum Pistense (Edict of Pîtres, 864) } \\ & \text { Getter from the Synod of Quierzy to King Louis the } \\ & \end{array}$


GA Asserii gesta AElfredi (Asser's Deeds of Alfred)

GPA Gesta pontificum Autissiodorensium (Deeds of the Bishops of Auxerre)

GSR Gesta sanctorum Rotonensium (Deeds of the Saints of Redon)

HE Hincmari archiepiscopi Remensis epistolae (Letters of Archbishop Hincmar of Rheims)

HRE Flodoardi historia Remensis ecclesiae (Flodoard's History of the Church of Rheims)

IRCA Institutio et Regula canonicorum in concilio Aquisgranensi (816) editae (Canonical Instruction and Rule Produced by the Council of Aachen)

LPW Libellus proclamationis adversus Wenilonem (Proclamation against Wenilo, 859)

LR Liber revelationum Audradi modici (Audrad's Book of Revelations)

Lupus Lupi abbatis Ferrariensis epistolae (Letters of Abbot Lupus of Ferrières)

MSF Ermentarii miracula sancti Filiberti (Ermentar's Miracles of St. Philibert)

MSB Adrevaldi miracula sancti Benedicti (Adrevald's Miracles of St. Benedict)

MSBr Miracula sancti Bertini (Miracles of St. Bertin)

MSR Miracula sancti Richarii (Miracles of St. Richarius)

$\mathrm{MGH} \quad$ Monumenta Germaniae Historica

AA Auctores antiquissimi

Capit. Capitularia regum Francorum

Conc. Concilia

Const. Constitutiones et acta publica imperatorum et regum

DD Kar. Diplomatum Karolinorum

Epp. Epistolae

Epp.sel. Epistolae selectae

Poetae Poetae Latini medii aevi

SS Scriptores

SRG Scriptores rerum Germanicarum in usum scholarum separatim editi

SRG NS Scriptores rerum Germanicarum, Nova series

SRM Scriptores rerum Merovingicarum

PL Patrologia Latina

PSA Poetae Saxonis annalium de gestis Caroli magni imperatoris (The Saxon Poet's Annals of the Deeds of Emperor Charles the Great)

RP Reginonis Prumiensis chronicon (Chronicle of Regino of Prüm)

SCV Sermo de relatione corporis beati Vedasti (Sermon on the Return of the Body of St.Vaast)

SScot Sedulii Scottii carmina (Sedulius Scottus' Poems)

TSG Translatio sancti Germani Parisiensis (Translation of St. Germain of Paris) 
xviii List of abbreviations

TSM Tours Miscellany (MS 106)

VA Rimberti vita sancti Anskarii (Rimbert's Life of St. Anskar)

VF Hildegari vita Faronis episcopi Meldensis (Hildegar's Life of Bishop Faro of Meaux)

VKM Einhardi vita Karoli magni (Einhard's Life of Charles the Great)

VW Alcuini vita sancti Willibrordi (Alcuin's Life of St. Willibrord)

Wid Widukindi rerum gestarum Saxonicarum (Widukind's Deeds of the Saxons) 


\section{Introduction}

Woe to you, Francia, now without a protector, How you are overwhelmed by destruction!

You are open on all sides to savage raiders

And, though once you were happy, now you are wretched.

Your enemies take malicious delight in your tears

And are steadily enriched by your spoils.

Thousands are slaughtered and the host of captives

Is greater in number than the sands of the sea.

For with the death of Charlemagne all your honour and glory

Has slowly and surely perished and fled. ${ }^{1}$

This is how an anonymous late ninth-century Saxon poet summarised his thoughts on the external forces that had troubled the Frankish realm since the passing of its first emperor, Charles, in 814. Whilst not identifying any clearcut culprits, the author seems to have alluded to the conduct of Scandinavian vikings, whose recurrent regional presence weighed equally heavily on the minds of many of his contemporaries. As such, his was not an exceptional narrative: it echoed the laments of numerous monastics who, for years, had seen their kingdoms, their communities, and even their own lives threatened by this enduring foreign peril.

Much like their Anglo-Saxon and Irish counterparts, the earliest known continental records to feature viking endeavour belong to the years surrounding the turn of the ninth century, a time when the expansive Frankish territories were staunchly governed by the Carolingian dynasty. Over the course of the decades, these Scandinavian seafarers began to grow in confidence and capability, turning their attention to some of the foremost centres of wealth and population across the region's interior. As hostilities intensified, so too did acts of domestic resistance and appeasement, which dissuaded some vikings, encouraged others, and even convinced a select few to pledge their services and loyalties to the Carolingian cause. 


\section{I.1 The story so far}

The assorted activities of viking groups around the Frankish territories have been subject to careful academic scrutiny for well over a century. Of particular note remains the work of German historian Walther Vogel, whose seminal treatise, Die Normannen und das fränkische Reich, was first published in $1906 .{ }^{2}$ Having informed scholars such as Ferdinand Lot and Fernand Vercauteren, Vogel's volume remained authoritative into the second half of the twentieth century, when its itemised and often uncritical approach to the primary evidence - characterised as a 'conception événementielle de l'histoire' - was increasingly called into question. ${ }^{3}$ The 1960 s, in particular, saw renewed surveys of the available source material produced by authors like Albert d'Haenens and Peter Sawyer, both of whom argued for a more nuanced view on the overall destructiveness of the viking phenomenon, highlighting the hyperbolic nature of the textual corpus. ${ }^{4}$ A number of historians, including J.M. WallaceHadrill and C. Patrick Wormald, challenged this revisionist position, declaring contemporary authors to have acted with restraint, and vikings, first and foremost, with the 'predatory instincts of the warband'. ${ }^{5}$ In recent decades, a more balanced view on these interactions has come to prevail, as the focus of enquiry has continued to shift from individual episodes of viking activity to the societal and political influences they collectively exerted across the Carolingian domain. Particularly prominent among these latter studies are those carried out by Simon Coupland and Pierre Bauduin. ${ }^{6}$

The regional politico-economic environment within which vikings were able to appear and advance themselves has likewise been thoroughly examined. Despite retaining its adherents as recently as the 1980s, Henri Pirenne's hypothesis of Carolingian commercial stagnation - a result of its purported isolation from the Mediterranean - has since been largely discredited. ${ }^{7}$ Pointing to a growing assembly of archaeological evidence, economic historians like Richard Hodges, Michael McCormick, and Adriaan Verhulst have instead strengthened the notion that the Carolingian economy was one of tremendous connectivity and liveliness, even as it began to experience the effects of Scandinavian antagonism during the ninth century. ${ }^{8}$ The integral role of Frisian merchants within this interwoven system has also been repeatedly emphasised, most notably by Stéphane Lebecq. ${ }^{9}$ In like manner, an increasingly robust understanding of Carolingian political organisation has emerged, in no small part due to the efforts of scholars like François-Louis Ganshof, Janet Nelson, and Rosamond McKitterick. ${ }^{10}$

Most of this regionally focussed research may be readily positioned within the paradigmatic currents that shaped the wider twentieth-century study of viking seafarers, the people they interacted with, and the world(s) they collectively inhabited. Beyond the tides of antiquarianism and nationalist rhetoric, an increasingly analytical, systemic, and longue-durée approach to the viking phenomenon emerged during the post-war period, finding particular parallels in the processual archaeology of the 1960s and 1970s. ${ }^{11}$ As the subsequent decades 
witnessed a countermovement to this structural approach, various hermeneutic perspectives - emphasising the experience and agency of the individual - began to find favour instead. ${ }^{12}$ Nevertheless, a gradual return to systems thinking has manifested itself in recent years: the employment of migration theory to examine early Scandinavian settlement in eastern England, for example, features prominently in research by Shane McLeod, whilst Judith Jesch and others have engaged the tenets of diaspora theory to investigate the cultural ties and transformations that typified the viking expansion. ${ }^{13}$ In archaeology, the use of network analysis to chart this wider connectivity has also made considerable headway, and is especially pronounced in the work of Søren Sindbæk. ${ }^{14}$ Taking its cue from this prevalent cross-disciplinary climate, this study will likewise adopt an underutilised theoretical approach - the application of conceptual models - to reconsider the reach and repercussions of viking activity across the Frankish realm, in particular.

Before embarking on any such study of early Franco-Scandinavian interaction, it is worth reaffirming that the overall ambit of viking influence extended well beyond the waterways of northern and western Europe, representing a prolonged movement that encountered and engaged a plethora of peoples and cultures across various different continents. Further west, beyond the BritishIrish Isles, many found their way across the Atlantic Rim, reaching the Faroe Islands, Iceland, Greenland, and the eastern seaboard of North America. ${ }^{15}$ Southwards, viking hosts managed to circumnavigate the Iberian Peninsula, landing on the shores of the Mediterranean basin. ${ }^{16}$ To the east, across the Baltic Sea, Scandinavians also plied the Rivers Dnieper and Volga, allowing them to reach the Black and Caspian Seas, as well as the Byzantine and Islamic markets that adjoined them. ${ }^{17}$ As such, even though this book will dedicate most of its attention to the viking activity in and around western mainland Europe, it should be recognised that the region represented only part of a much more expansive, interconnected network of contemporary Scandinavian endeavour.

\section{I.2 Modelling viking activity in Francia}

Despite considerable strides having been made in the analysis and assessment of viking behaviour around the European mainland, these advancements have often been constrained by the inherent limitations of flawed bodies of primary evidence. On account of their fragmentary and often tendentious disposition, (semi-)contemporary sources have continued to promote the perception of a regional Scandinavian encroachment that was largely without focus, forethought, or forbearance. Accordingly, many such accounts emphasise these external forces to have traversed the Frankish realm with indiscriminate brutality and rancour, as they 'ransacked and despoiled, massacred, burned, and ravaged'. ${ }^{18}$ However, even in such polemical works, rudimentary patterns of viking movement are discernible, as particular types of targets were seemingly favoured, recurrent formulae of attack, defence, and withdrawal were adopted, and various accessory endeavours - including encampment and political 
engagement - were pursued. Likewise, when considered more broadly, many such expeditions seem to have stretched across considerable distances and periods of time, raising distinct questions on organisation and intent.

Whereas the structural and logistical management of viking hosts in Britain and Ireland has been subject to recurrent (albeit intermittent) scrutiny, inquiries into corresponding planning and decision-making processes on the Continent remain relatively sparse, particularly in Anglophone scholarship. ${ }^{19}$ As such, even though viking endeavour itself has been well-attested across the wider Frankish world, its underlying practicalities - including methods of communication, resource provision, and contingency planning - have hitherto not been explored in extensive detail. Since organisational factors like these would have been paramount to the sustained viability of overseas Scandinavian movement, an appropriate initial research question to be posed would be: how did these viking groups structure and sustain themselves whilst operating within the Frankish territories? Furthermore, even though certain routines and regularities are apparent in the demeanour of regionally active viking hosts, these patterns have yet to be systematically identified, quantified, and presented in a manner that allows for meaningful analysis and interpretation, leaving the catalysts and coordination of these exploits largely up for debate. As such, a second, more significant research question to be advanced is: did these regional actions adhere to any determinable overarching scheme of Franco-Scandinavian interaction, and, if so, what does this signify?

In the absence of newly uncovered evidence, a thorough, cumulative reinterpretation of the available source material is warranted to address these points at issue. By considering the aggregate of viking endeavour across the Frankish realm, this study will approach its development on a more conceptual level, allowing prevailing spatiotemporal patterns of movement and interaction to be discerned and defined. As well as correlating such activity to specific politicoeconomic prerequisites, this process of pattern recognition aims to demonstrate that regional viking movement was seldom arbitrary or uncoordinated in character, but, rather, part of a far more structured, underlying framework of Scandinavian agency. This framework will be represented and visualised as a so-called conceptual development model - an abstract, phased paradigm of archetypal activity based on the compiled and collated data from the primary sources. Apart from contributing to a more comprehensive narrative of continental viking interaction, this model will facilitate the deductive analysis of said interaction for localities within which primary evidence has thus far been ambiguous or wholly absent.

On a rudimentary level, conceptual models represent structured, abstract renditions of reality or other systems of relationships, formulated to accentuate specific (series of) characteristics therein. ${ }^{20}$ Often advanced as narrative and/ or visual frameworks, they enable large, intricate sets of data to be collected, classified, and presented in a manner that makes them easier to examine or otherwise engage with, whilst facilitating the discernment of overarching patterns and correlations. The use of conceptual models to denote and analyse 
the terrestrial and transmarine movement of people, for example, enjoys an established position in the field of human geography, where spatiotemporal processes of migration, commerce, settlement, and infrastructural development have all been subject to this particular methodology. ${ }^{21}$ By shifting the analytical focus from individual or isolated events to overarching socio-economic structures, such models allow scholars to draw meaningful conclusions from wider, interdisciplinary bodies of primary evidence - compiled and crossreferenced to diminish, as much as possible, any absences or anomalies in their constituent sources. ${ }^{22}$ For this reason, conceptual models represent valuable tools for the analysis of specific historical phenomena, including, as proposed here, the far-reaching itinerancy and interaction of viking hosts around the Frankish realm.

Although by no means commonplace, the application of structural, sequential models in scrutinising the development of viking activity cannot be considered an altogether novel approach. Whilst prior scholars like Marc Bloch and Johannes Brøndsted already advocated the chronological partitioning of the viking phenomenon, a more bespoke sequence of development for northwestern Europe was first put forward by Lucien Musset. ${ }^{23}$ Split into three distinct phases, his schema opens with a gradual expansion of Scandinavian antagonism along regional coastlines and inland rivers, followed by an alleged Danegeld phase, wherein violence - or the threat thereof - would have been primarily used to intimidate and to exact regional tributes. Afterwards, a concluding phase of 'direct exploitation' involved the establishment of various Scandinavian 'states' within these overseas territories, as viking groups began to settle and integrate into their host society. ${ }^{24}$ Whilst having been - and continuing to be - widely recognised, Musset's model is not without its weaknesses: apart from its overall lack of detail, it spends little time on the contextual aspects of these consecutive viking movements, with no mention made of preceding commerce and communication between Scandinavia and the overseas region in question. ${ }^{25}$

Instead of taking its cue from preceding paradigms, the conceptual model introduced by this study represents an original construct, informed by the appraisal and geospatial analysis of the available interdisciplinary evidence. As well as outlining the assorted activities of vikings themselves, it strives to integrate the politico-economic context and repercussions of these endeavours, both in Francia and Scandinavia. Its sequential framework, encompassing four distinct phases of Franco-Scandinavian interaction, will be accompanied by an abstract spatial schematic, whose visual design is inspired by existent economic models of transmarine development, including those produced by James E. Vance and Peter Rimmer (see Figures I.1a and b). ${ }^{26}$ The temporal range of the model is set - roughly - between the mid-eighth and mid-tenth centuries, encompassing the vast majority of evidenced viking activity within the Frankish territories, from passing trade to permanent settlement.

Following the step-by-step development of the conceptual model, its overall validity and value will be determined by its application to three territorially 


\section{New World}

The overseas colony

Stage 1: Initial searching phase

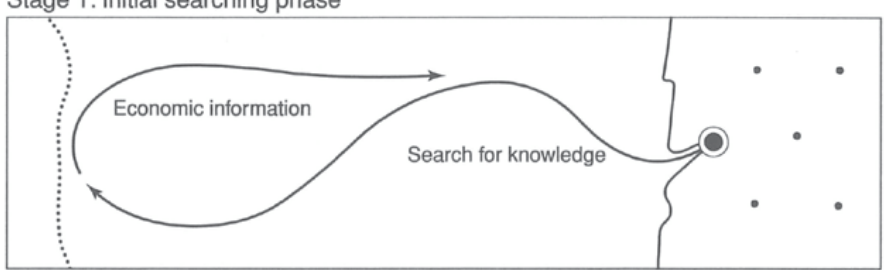

Stage 2: Testing productivity and harvest of natural storage

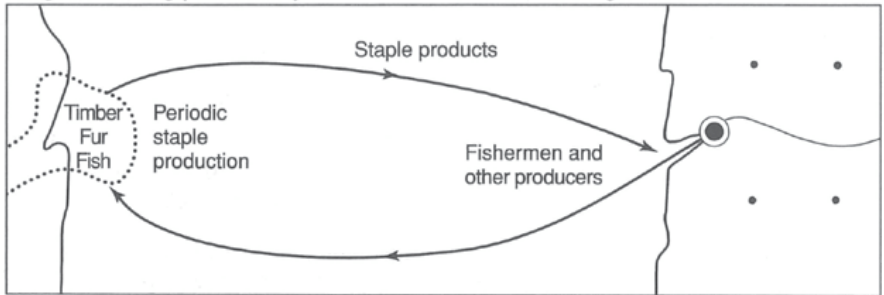

Stage 3: Planting of settlers

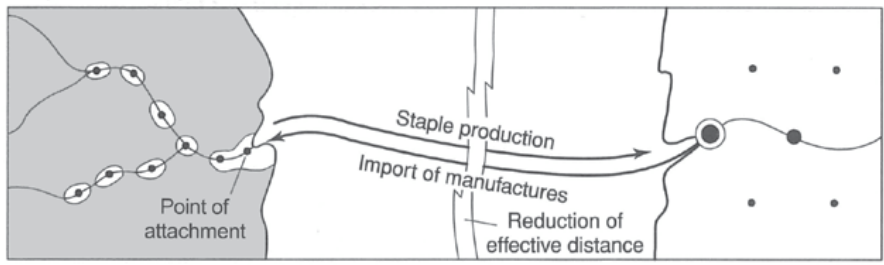

Stage 4: Increasing trade

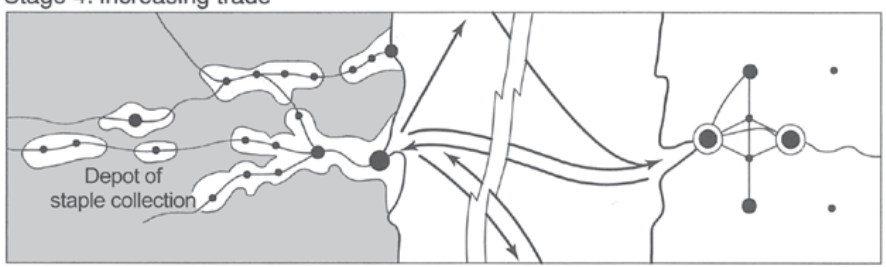

Stage 5: Final pattern

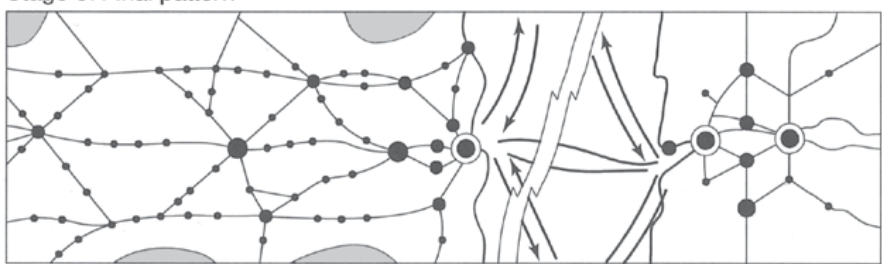

Mercantile model with central place infilling
Central place market with a mercantile overlay

\section{Unoccupied and lightly settled areas}

Figure I.1 (a) James E. Vance's transmarine mercantile model (after Vance, Merchant's World, 151). Reproduced with kind permission. 

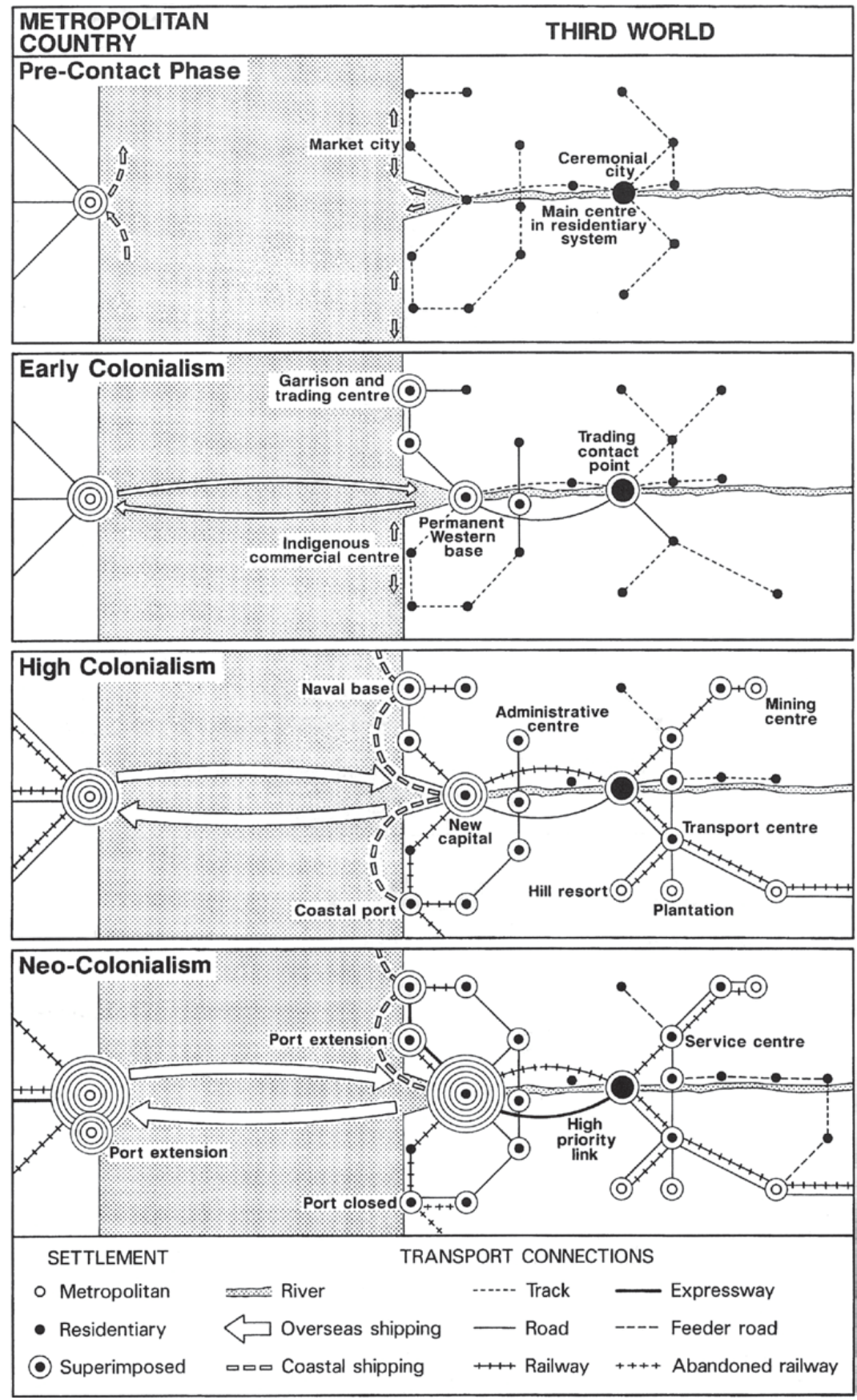

Figure I.1 (b) Peter Rimmers's hybrid transport system (after Rimmer, "Conceptual Framework," 134). (C) Wiley, Victoria University of Wellington. Reproduced with kind permission. 


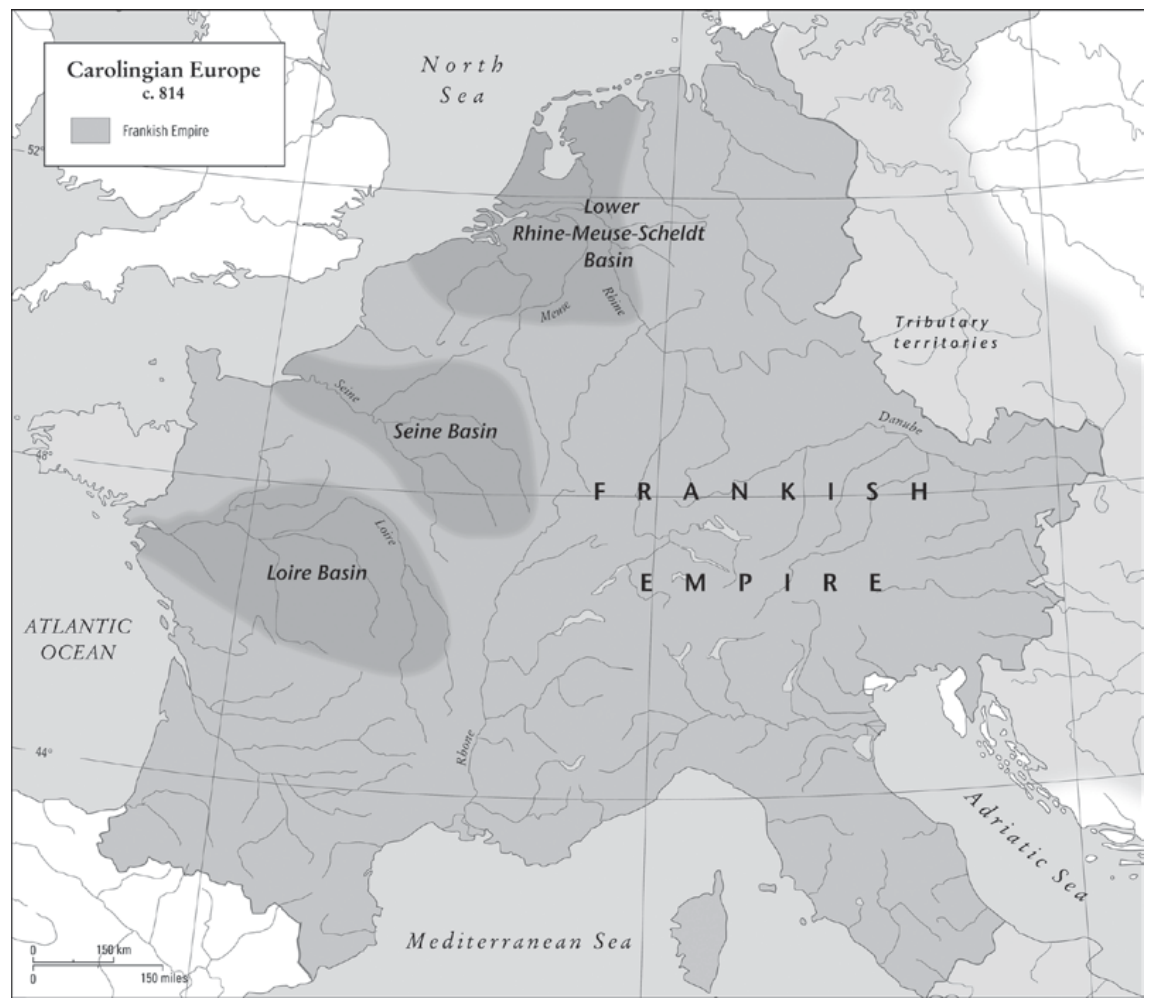

Figure I.2 Carolingian Europe at its largest extent (c. 814), representing this study's principal region of inquiry. Case studies are highlighted. (C) Swanston Map Archive.

confined case studies: the lower Rhine-Meuse-Scheldt basin, the Seine basin, and the Loire basin (see Figure I.2 for their location). Geographically dispersed across the Frankish realm, these respective regions have been purposely selected for their envelopment of major navigable river systems, which represent expansive corridors of waterborne commerce and communication - crosscutting and interconnecting both marginal and inland areas of political, economic, and cultural significance. All three case studies, furthermore, represent recognised points of convergence for mariners of diverse overseas origin - including Scandinavians - before and during the early Viking Age (see also Section VI.1.2.1, esp. Figure VI.5).

Over the course of this book, the respective components of this tailored conceptual model will be defined in logical succession, followed by their consolidation into a single, cohesive framework. Starting out, the second chapter will consider the sociopolitical and economic environment that enabled the viking phenomenon to take shape in Scandinavia. In addition, it will outline the 
concept of 'hydrarchy' as an organisational framework for the self-governance and self-sustenance of itinerant viking hosts. Chapter III will then highlight the politico-economic development of the Frankish realm between the mideighth and mid-tenth centuries, paying particular heed to mechanisms of elite power and patronage, as well as to the regional proliferation of production and trade. Building on these contextual parameters, the fourth chapter will examine established lines of commerce and other communication between the Frankish and Scandinavian spheres before the death of Charlemagne, representing the opening phase of the conceptual model. Its second phase, comprising the earliest decades of viking enmity and encroachment, will be formulated in ChapterV, whilst ChapterVI will consider a subsequent period of highly intensified Scandinavian interaction, followed by the eventual abatement of such activity around the Frankish kingdoms. At this point, the penultimate chapter will draw these building blocks together into an overarching model that will then be validated using the abovementioned regional case studies. Having thus been assessed, the significance of the model in interpreting the characteristics of viking conduct around the European mainland will be deliberated in the overall concluding remarks.

All in all, by introducing and implementing an original methodological framework to reconsider regional viking movements around the Frankish realm, this study allows overarching patterns of said endeavour to be identified and interpreted, offering a beneficial, novel perspective on the logistical and strategic considerations that would have governed them. Likewise, due to its focus on a sizeable yet comparatively underrepresented portion of the wider viking world, it will amass and accommodate bodies of evidence that have hitherto often been divided across disciplinary, linguistic, and geopolitical lines. ${ }^{27}$ By pairing this respective source material and research methodology - and presenting them to a wider academic audience - this work aspires to open up future opportunities for comparative and critical study of this far-reaching Scandinavian presence across the European mainland.

\section{I.3 Primary sources}

In support of its argument, this work will draw on as wide and diverse a corpus of primary data as possible. By necessity, this entails that a predominant share of pertinent sources will be documentary in nature, due in large part to the relatively restricted amount of artefactual and otherwise archaeological evidence ascribed to regional viking activity. ${ }^{28}$ Likewise, the prevalence of onomastic evidence is mostly limited to the coastal and riverine reaches of the former duchy of Normandy, where many (Anglo-)Scandinavian place-names remain difficult to assign to any specific date or even date range. ${ }^{29}$

In identifying and typifying viking movement across the Frankish realm, a broad range of written sources will be relied on, from narrative to bureaucratic, from pragmatic to poetic. Of particular value are accounts produced 
within living memory of the events they describe, including principal Frankish chronicles, capitularies, and personal correspondence. Although deemed more reliable than later sources broaching the same subject matter, these (semi-) contemporary records should not be approached without caution or critique. Inherent to their authorship, many of them betray a distinct ecclesiastical bias, which regarded vikings to have been brought forth by divine providence rather than human agency - 'savages' set loose to punish the faithful for their transgressions. ${ }^{30}$ By issuing blanket statements of widespread, wholesale bloodshed and destruction, numerous Carolingian literati are considered to have embellished the threat these external forces posed to the Frankish realm, its institutions, and its populace. ${ }^{31}$ In similar fashion, the size, agency, and leverage of individual Scandinavian hosts may have been deliberately overstated to further emphasise their ferocity and impact. ${ }^{32}$ Lastly, some chroniclers may have prioritised local events over those occurring further afield, whilst political partisanship may have led others to accentuate, abridge, or otherwise amend their particulars.

As well as being cognisant of these biases, this study will purposely disregard a number of semi-contemporary documents for their precarious overall credibility. Among these is the Miracula sancti Germani, composed during the second half of the ninth century by Aimoin, monk of St. Germain-des-Prés. In the preface to this work, the author admits to having conflated multiple earlier accounts of viking activity along the Seine, thus considerably - and near-inextricably - increasing the likelihood of anachronism. ${ }^{33}$ Also omitted is the influential late tenth- to early eleventh-century Historia Normannorum of Dudo of St. Quentin, whose panegyric narrative on the Rollonid dynasty and its initial assumption of power in Normandy has been widely called into question. $^{34}$

Compared to the concurrent corpuses of Anglo-Saxon England, Scotland, and Ireland, material vestiges for viking movement around the Frankish realm remain notably meagre. Apart from a single boat burial - located on the Île de Groix - no undisputed funerary evidence of Scandinavian character has yet been put forward. ${ }^{35}$ Similarly scarce are the physical remains of viking encampments, which, by contrast, feature prominently in the documentary record. ${ }^{36}$ More plentiful, however, are direct traces of regional Scandinavian incursion, as destruction layers in towns like Rouen, Liège, and Deventer - as well as various rural monasteries - have been ascribed to known episodes of local viking antagonism. ${ }^{37}$ When treated with appropriate caution, chance finds likewise continue to represent a valuable source of evidence for this extraneous presence, as growing numbers of armaments, hoards, and other pertinent artefacts have been identified over the past several decades. ${ }^{38}$

\section{I.4 Terminology and definitions}

In its characterisation of vikings and their pursuits, this volume will - except when translating or quoting - steer clear of commonplace designations such 
as 'pirate', 'marauder', 'invader', 'warlord', 'warband', 'horde', and 'swarm', all of which may be considered reductive, partisan, or even derogatory. Likewise, in lieu of conceptually loaded terms like 'raid', 'plunder', and 'pillage' (and their derivatives), a more neutral nomenclature - including 'attack' and 'incursion' will be employed. Although the label 'viking' is itself not without connotation, it is used here for convenience and recognisability, denoting a Scandinavian or concomitant mariner engaged in any overseas combination of incursionary, mercantile, or political endeavour for personal or collective sociomaterial advancement, active between the mid-eighth and mid-eleventh centuries. ${ }^{39}$ Thus, whilst primarily associated with Scandinavian activity - and often identified as such within this work - the term is not, strictly speaking, ethnic, but occupational. As such, it will be presented as a common noun, in lowercase. Wherever possible, personal names and place-names will be provided in their Anglicised and/or most prevalent forms.

As may be inferred from the title of this research, its principal geographical focus will be the 'Frankish realm', an ambiguous phrase for which further specification is warranted: included here are all territories constituting the Carolingian Empire at its greatest extent (i.e. during the early ninth century), regardless of subsequent division and consolidation. ${ }^{40}$ This substantial domain was made up of manifold pagi (sg. pagus), fundamental units of politicoadministrative jurisdiction, which were themselves often united into comitatus (sg. comitatus, 'county'). ${ }^{41}$ Within these districts, overlapping classifications were often used to denote centres of population. Civitates (sg. civitas), for example, generally represent locations of episcopal seats, and should, as such, not be translated to the less specific 'cities' or 'towns'. ${ }^{42}$ Whilst both castellum (pl. castella) and castrum (pl. castra) indicate the presence of fortified enclosures, urbs (pl. urbes) usually signifies a larger walled nucleus. ${ }^{43}$ Vicus (pl. vici) and portus (pl. portus) both commonly - but not invariably - allude to mercantile centres, with the latter of the two placing particular emphasis on waterborne activity. ${ }^{44}$ Villa (pl. villae), lastly, is used to represent a conglomeration of rural households, and may be translated as 'estate', 'manor', 'settlement', or even just 'village'. ${ }^{45}$ By and large, due to their variable definitions - as well as the anachronistic overtones of their modern English counterparts - all of the above politico-administrative terms will not be translated from their Latin originals.

A number of definitions on periodisation should likewise be clarified. The so-called Viking Age, first and foremost, is a relatively recent concept, often loosely outlined as the time span between the late eighth and mid-eleventh centuries. ${ }^{46}$ In light of prior Scandinavian commerce and communication around the North and Baltic Seas, however, a compelling argument may be (and has been) made to move the onset of this period back by at least several decades. ${ }^{47}$ In accordance, this study regards the Viking Age to have begun around the middle of the eighth century. In Scandinavia itself, this period was preceded by a Nordic Iron Age (c. 500 BCE-750 CE), whose lattermost subdivisions - the Roman Iron Age (c. 1-400 CE) and Germanic Iron Age (c. 400-750 CE) - will be examined in Chapter II. ${ }^{48}$ In the Frankish realm, a 
'Carolingian period' - here defined by dynastic control of royal power - began with the accession of Pippin 'the Short' in 751, and ended with the death of Louis V in 987.

Unless otherwise noted, all translations from the Latin are the author's.

\section{Notes}

1 Ve tibi vae tali modo defensore carenti / Frantia, quam variis cladibus opprimeris! / Gentibus ecce pates populantibus undique saevis / Et, quondam felix, nunc nimis es misera. I Quippe tuis hilares exultant fletibus hostes / Ditanturque tuis assidue spoliis; / Milia cesorum, captivaque turba tuorum / Amplior est numero quam sit harena maris. / Nam Carolo moriente tuum decus et honor omnis / Ex illo sensim fugit et interiit. Poeta Saxo, "Annalium de gestis Caroli magni imperatoris," in MGH Poetae IV, ed. Paul von Winterfeld (Berlin: Weidmann, 1899), 64-65. Translation from Theodore Andersson, "The Viking Image in Carolingian Poetry," in Les relations littéraires franco-scandinaves au Moyen Âge, ed. Maurice Gravier Delbouille (Paris: Les Belles Lettres, 1975), 241.

2 WaltherVogel, Die Normannen und das fränkische Reich bis zur Gründung der Normandie (799-911) (Heidelberg: Winter, 1906).

3 Ferdinand Lot, "La grande invasion normande de 856-862," Bibliothèque de l'école des chartes 69 (1908): 5n1; F. Vercauteren, "Comment s'est-on défendu, au IX è siècle dans l'empire franc contre les invasions normandes?", in Annales du XXX congrès de la fédération archéologique et historique de Belgique (Brussels: La Fédération, 1936), 117. The characterisation is found in Albert d'Haenens, "Les invasions normandes dans l'empire franc au IX ${ }^{\mathrm{e}}$ siècle," in I Normanni e la loro espansione in Europa nell'alto medioevo, ed. Centro italiano di studi sull'alto medioevo (Spoleto: Presso la Sede del Centro, 1969), 235-238. See also Pierre Bauduin, Le monde franc et les Vikings: VIII ${ }^{e}-X^{e}$ siècle (Paris: Albin Michel, 2009), 37-38.

4 Peter Sawyer, The Age of the Vikings, 2nd ed. (London: Edward Arnold, 1971), 28-32; Albert d'Haenens, Les invasions normandes, une catastrophe? (Paris: Flammarion, 1970), 95-106.

5 J.M. Wallace-Hadrill, The Vikings in Francia, Stenton Lecture (Reading: University of Reading, 1975), 7; C. Patrick Wormald, "Viking Studies: Whence and Whither?," in The Vikings, ed. R.T. Farrell (London: Phillimore, 1982), 144. The quote originates from the latter source.

6 See, for example, Simon Coupland, "The Carolingian Army and the Struggle against the Vikings," Viator 35 (2004): 49-70; Bauduin, Le monde franc et les Vikings.

7 Henri Pirenne, "Mahomet et Charlemagne," Revue belge de philologie et d'histoire 1, no. 1 (1922): 77-86; Richard Hodges and David Whitehouse, Mohammed, Charlemagne $\mathcal{E}$ the Origins of Europe (Duckworth, 1983), 175-176.

8 Richard Hodges, "North Sea Trade before the Vikings," in Archaeological Approaches to Medieval Europe, ed. Kathleen Biddick (Kalamazoo: Western Michigan University, 1984), 199; Michael McCormick, Origins of the European Economy: Communications and Commerce AD 300-900 (Cambridge: Cambridge University Press, 2001), 2-6; Adriaan Verhulst, The Carolingian Economy (Cambridge: Cambridge University Press, 2002), 132-135.

9 Stéphane Lebecq, Marchands et navigateurs frisons du haut Moyen Age, vol. I (Lille: Presses Universitaires de Lille, 1983). 
10 See, for example, François-Louis Ganshof, Frankish Institutions under Charlemagne (Providence: Brown University Press, 1968); Janet Nelson, The Frankish World: 750-900 (London: Hambledon, 1996); Rosamond McKitterick, The Frankish Kingdoms under the Carolingians: 751-987 (London: Longman, 1983).

11 Eric Christiansen, The Norsemen in the Viking Age (Oxford: Blackwell, 2006), 318-319. See also Andrew Sherratt, "What Can Archaeologists Learn from Annalistes?," in Archaeology, Annales, and Ethnohistory, ed. A. Bernard Knapp (Cambridge: Cambridge University Press, 1992), 135-136.

12 Tina L. Thurston, Landscapes of Power, Landscapes of Conflict: State Formation in the South Scandinavian Iron Age (New York: Kluwer, 2002), 30-31. See also Roberta Gilchrist, "Medieval Archaeology and Theory: A Disciplinary Leap of Faith," in Reflections: 50 Years of Medieval Archaeology, 19572007, ed. Roberta Gilchrist and Andrew Reynolds (London: Maney, 2009), 387-388.

13 Shane McLeod, The Beginning of Scandinavian Settlement in England: The Viking "Great Army" and Early Settlers, c. 865-900 (Turnhout: Brepols, 2014), 43-108; Judith Jesch, The Viking Diaspora (Abingdon: Routledge, 2015), 69-81.

14 See, for example, Søren Sindbæk, "Broken Links and Black Boxes: Material Affiliations and Contextual Network Synthesis in the Viking World," in Network Analysis in Archaeology: New Approaches to Regional Interaction, ed. Carl Knappett (Oxford: Oxford University Press, 2013), 71-94.

15 For more detailed discussions on the viking presence around the North Atlantic, see, for example, James H. Barrett, ed., Contact, Continuity, and Collapse: The Norse Colonization of the North Atlantic (Turnhout: Brepols, 2003).

16 A recent deliberation of the evidence for viking activity around the Mediterranean may be found, for example, in Ann Christys, Vikings in the South: Voyages to Iberia and the Mediterranean (London: Bloomsbury, 2015).

17 See,for example,Wladyslaw Duczko, Viking Rus': Studies on the Presence of Scandinavians in Eastern Europe (Leiden: Brill, 2004). A brief consideration of Scandinavian trade along the eastern rivers is also found in Section II.2.2.

18 Prosternunt, spoliant, perimunt, urunt, populantur, [...]. Text and translation from Abbo, Viking Attacks on Paris: The Bella Parisiacae Urbis of Abbo of Saint-Germain-des-Prés, ed. Nirmal Dass (Paris: Peeters, 2007), 38-39.

19 Recent studies on Insular viking organisation include, for example, Gareth Williams, "Viking Camps and the Means of Exchange in Britain and Ireland in the Ninth Century," in The Vikings in Ireland and Beyond: Before and After the Battle of Clontarf, ed. Howard Clarke and Ruth Johnson (Dublin: Four Courts, 2015), 93-116; Ben Raffield, "Bands of Brothers: A Re-Appraisal of the Viking Great Army and its Implications for the Scandinavian Colonization of England," Early Medieval Europe 24, no. 3 (2016): 308-337.

20 Peter Haggett, Andrew Cliff, and Allan Frey, Locational Analysis in Human Geography, 2nd ed. (London: Edward Arnold, 1977), 17; Roger Brunet, Sustainable Geography (Hoboken, NJ: Wiley, 2010), 214.

21 See, for example, Jean-Paul Rodrigue, The Geography of Transport Systems, 4th ed. (New York: Routledge, 2017).

22 Iain S. Black, "Analysing Historical and Archival Sources," in Key Methods in Geography, ed. Nicholas Clifford, Shaun French, and Gill Valentine, 2nd ed. (London: SAGE, 2010), 467-469, 481-482; Josiah Ober, "Models and Paradigms in Ancient History," The Ancient History Bulletin 3, no. 6 (1989): 134-137. 
23 Marc Bloch, La société féodale (Paris: Albin Michel, 1939), 34-39; Johannes Brøndsted, Die große Zeit der Wikinger (Neumünster: Wachholtz, 1964), 27-30; Lucien Musset, Les invasions: le second assaut contre l'Europe chrétienne (VII ${ }^{e}-X I^{e}$ siècles), 2nd ed. (Paris: Presses Universitaires de France, 1971), 135-137.

24 Ibid., 136.

25 Recently, the model has been cited by Pierre Bauduin, Les Vikings (Paris: Presses Universitaires de France, 2018), 52; Stephen M. Lewis, "Salt and the Earliest Scandinavian Raids in France: Was there a Connection?," Viking and Medieval Scandinavia 12 (2016): 104.

26 Both of these visual models were conceived to illustrate the development of trade and transport networks between colonial powers and their respective overseas colonies. See James E. Vance, The Merchant's World: The Geography of Wholesaling (London: Prentice-Hall, 1970), 151; Peter Rimmer, “A Conceptual Framework for Examining Urban and Regional Transport Needs in South-East Asia," Pacific Viewpoint 18, no. 2 (1977): 134.

27 See also Anne Nissen-Jaubert, "Some Aspects of Viking Research in France," Acta Archaeologica 71 (2000): 159-161.

28 The confined character of this material evidence is discussed, for example, by Ibid., 165-167; Else Roesdahl, "What May We Expect? On the Problem of Vikings and Archaeology in Normandy," in La progression des Vikings, des raids à la colonisation, ed. Anne-Marie Flambard Héricher (Rouen: Université de Rouen, 2003), 207-213.

29 See, for example, Gillian Fellows-Jensen, "Scandinavian Place-Names and Viking Settlement in Normandy: A Review," Namn och bygd 76 (1988): 133-134; Lesley Abrams, "Early Normandy," in Anglo-Norman Studies XXXV: Proceedings of the Battle Conference 2012, ed. David Bates (Woodbridge: Boydell, 2013), 52, 57-58.

30 Simon Coupland, “The Rod of God's Wrath or the People of God's Wrath? - The Carolingian Theology of the Viking Invasions," Journal of Ecclesiastical History 42 (1991): 537-540.

31 See, for example, Simon Coupland, "Holy Ground? The Plundering and Burning of Churches by Vikings and Franks in the Ninth Century," Viator 45 (2014): 76-80.

32 Gareth Williams, "Raiding and Warfare," in The Viking World, ed. Stefan Brink and Neil Price (London: Routledge, 2008), 193, 195-196. See also Section VI.1.

33 Aimoin, "De miraculis sancti Germani," in PL CXXVI, ed. Jacques-Paul Migne (Montrouge: Migne, 1852), cols. 1027-1028.

34 Eleanor Searle, Predatory Kinship and the Creation of Norman Power, 840-1066 (Berkeley: University of California Press, 1988), 62; Nick Webber, The Evolution of Norman Identity, 911-1154 (Woodbridge: Boydell, 2005), 22.

35 Although a pair of oval brooches from Pîtres has been linked to a supposed woman's grave, the anecdotal nature of its nineteenth-century discovery - and lack of contextual evidence - preclude further validation. See J.B.D Cochet, "Note sur des fibules scandinaves - Trouvées à Pîtres, près le Pont-de-l'Arche, et entrées au musée d'Antiquités de Rouen," in Précis analytique des travaux de l'Académie impériale des sciences, belles-lettres et arts de Rouen, 1869-1870 (Rouen: Boissel, 1870), 412; Patrick Périn, "Les objets vikings du musée des Antiquités de la Seine-Maritime, à Rouen," Cahier des Annales de Normandie 23 (1990): 163-164. See SectionVI.1.1.1 for the Île de Groix burial.

36 For a more extensive consideration of the documentary and archaeological evidence for regional viking encampment, see Section VI.2.2.

37 A more detailed enumeration may be found in Section VI.1.3. 
38 See, for example, Élisabeth Ridel, ed., "Corpus des objets vikings découverts en France," in Les Vikings dans l'empire franc (Bayeux: OREP, 2014), 130-135; Annemarieke Willemsen, "Scattered across the Waterside: Viking Finds from the Netherlands," in Vikings on the Rhine: Recent Research on Early Medieval Relations between the Rhinelands and Scandinavia, ed. Rudolf Simek and Ulrike Engel (Vienna: Fassbaender, 2004), 65-82; Holger Arbman and Nils-Ove Nilsson, "Armes scandinaves de l'époque viking en France," Meddelanden frän Lunds universitets historiska museum no. 1966-1968 (1969): 163-202.

39 For a more detailed discussion on the early medieval etymology and usage of the term, see Stefan Brink, "Who Were the Vikings?," in The Viking World, ed. Stefan Brink and Neil Price (London: Routledge, 2008), 5-7.

40 See Figure I.2 for an overall map of this territory. Although the name 'Francia' has been taken to denote different lands at different times, it will here be used interchangeably with the Frankish realm as a whole. See McKitterick, Frankish Kingdoms, 18-19.

41 Marios Costambeys, Matthew Innes, and Simon MacLean, The Carolingian World (Cambridge: Cambridge University Press, 2011), 172; Matthew Innes, State and Society in the Early Middle Ages: The Middle Rhine Valley, 400-1000 (Cambridge: Cambridge University Press, 2000), 119-120.

42 Janet Nelson, trans., The Annals of St. Bertin (Manchester: Manchester University Press, 1991), 18.

43 Adriaan Verhulst, The Rise of Cities in North-West Europe (Cambridge: Cambridge University Press, 1999), 3, 84.

44 Ibid., 14, 48-49; Stéphane Lebecq, "The New Wiks or Emporia and the Development of a Maritime Economy in the Northern Seas (7th-9th Centuries)," in From One Sea to Another: Trading Places in the European and Mediterranean Early Middle Ages, ed. Sauro Gelichi and Richard Hodges (Turnhout: Brepols, 2012), 15; Richard Coates, "New Light from Old Wicks: The Progeny of Latin Vicus," Nomina 22 (1999): 75-114.

45 Timothy Reuter, trans., The Annals of Fulda (Manchester: Manchester University Press, 1992), 13; Verhulst, Carolingian Economy, 32; Costambeys, Innes, and MacLean, Carolingian World, 229.

46 Although the early incursion on Lindisfarne (793) and later battle at Stamford Bridge (1066) have traditionally served to bookend this period, this convention has been criticised for its arbitrariness and Anglocentrism. See, for example, Brink, "Who Were the Vikings?," 5; Clare Downham, "The Earliest Viking Activity in England?," English Historical Review CXXXII, no. 554 (2017): 5-6; Aina Margrethe Heen-Pettersen, "The Earliest Wave of Viking Activity? The Norwegian Evidence Revisited,” European Journal of Archaeology 22, no. 4 (2019): 523-525; Angelo Forte, Richard Oram, and Frederik Pedersen, Viking Empires (Cambridge: Cambridge University Press, 2005), 4-10. The historical concept of a 'Viking Age' first emerged in the Scandinavian scholarship of the nineteenth century. See Jes Wienberg, "Vikings and the Western Frontier," in Small Things - Wide Horizons: Studies in Honour of Birgitta Hårdh, ed. Lars Larsson et al. (Oxford: Archaeopress, 2015), 290-291.

47 Jesch, The Viking Diaspora, 8; Bjørn Myhre,"The Beginning of theViking Age: Some Current Archaeological Problems," in Viking Revaluations, ed. Anthony Faulkes and Richard Perkins (London: Viking Society for Northern Research, 1993), 195199; Neil Price, "Pirates of the North Sea? The Viking Ship as Political Space," 
in Comparative Perspectives on Past Colonisation, Maritime Interaction and Cultural Integration, ed. Lene Melheim, Håkon Glørstad, and Zanette Tsigaridas Glørstad (Sheffield: Equinox, 2016), 158-162. See also Chapters IV and V.

48 Knut Helle, "Introduction," in The Cambridge History of Scandinavia, ed. Knut Helle, vol. I (Cambridge: Cambridge University Press, 2003), 5. To avoid potential confusion, the predominantly Swedish-focussed 'Vendel Period' will not be used in this study.

1 This development is discernible in the sudden replanning of Iron Age central places like Vorbasse (Jutland). See Bjørn Myhre, “The Iron Age," in The Cambridge History of Scandinavia, ed. Knut Helle, vol. I (Cambridge: Cambridge University Press, 2003), 70.

2 Charlotte Fabech, "Centrality in Sites and Landscapes", in Settlement and Landscape: Proceedings of a Conference in Arhus, Denmark, May 4-7 1998, ed. Charlotte Fabech and Jytte Ringtved (Moesgård: Jutland Archaeological Society, 1999), 457.

3 Ulf Näsman, "The Ethnogenesis of the Danes and the Making of a Danish Kingdom," Anglo-Saxon Studies in Archaeology and History 10 (1999): 4.

4 Lotte Hedeager, "Scandinavia before the Viking Age," in The Viking World, ed. Stefan Brink and Neil Price (London: Routledge, 2008), 18.

5 Myhre, "The Iron Age," 69-70; Lotte Hedeager, Iron Age Societies: From Tribe to State in Northern Europe, 500 BC to AD 700, trans. John Hines (Oxford: Blackwell, 1992), 253.

6 Charlotte Fabech and Jytte Ringtved, "Magtens geografi i sydskandinavian - Om kulturlanskab, produktion og bebyggelsesmønster," in Produksjon og Samfunn: Om erverv, spesialisering og bosetning $i$ Norden $i$ 1. artusen e.Kr, ed. Heid Gjøstein Resi (Oslo: Universitet i Oslo, 1995), 14.

7 T. Douglas Price, Ancient Scandinavia: An Archaeological History from the First Humans to the Vikings (Oxford: Oxford University Press, 2015), 262-281; Hedeager, "Scandinavia before theViking Age," 16-17; Morten Axboe, "Towards the Kingdom of Denmark," Anglo-Saxon Studies in Archaeology and History 10 (1999): 114; Dagfinn Skre, “The Warrior Manor," in Avaldsnes: A Sea-Kings' Manor in First-Millennium Western Scandinavia, ed. Dagfinn Skre (Berlin: de Gruyter, 2018), 772-779.

8 Price, Ancient Scandinavia, 292; Michael Olausson, “Fortified Manors in the Migration Period in the Eastern Part of Central Sweden - A Discussion of Politics, Warfare and Architecture," in Military Aspects of Scandinavian Society in a European Perspective AD 1-1300, ed.Anne Nørgård Jørgensen and Birthe L. Clausen (Copenhagen: National Museum of Denmark, 1997), 157-162; Frands Herschend, The Early Iron Age in South Scandinavia (Uppsala: Uppsala University, 2009), 362-364; Christian Juel and Mads Ravn, "Erritsø - A Fortified Early Viking Age Manor near Lillebælt," in The Fortified Viking Age, ed. Jesper Hansen and Mette Bruus (Odense: University Press of Southern Denmark, 2018), 17-20.

9 Ulf Näsman, “Comments on Inger Storli: 'Court Sites of Arctic Norway,'” Norwegian Archaeological Review 44, no. 1 (2011): 98; Frode Iversen, "Emerging Kingship in the 8th Century? New Datings of Three Courtyard Sites in Rogaland," in Avaldsnes: A Sea-Kings' Manor in First-Millennium Western Scandinavia, ed. Dagfinn Skre (Berlin: de Gruyter, 2018), 721-724.

10 Jytte Ringtved, “The Geography of Power: South Scandinavia before the Danish Kingdom," Anglo-Saxon Studies in Archaeology and History 10 (1999): 51, 55; Hedeager, Iron Age Societies, 170-173.

11 Myhre, “The Iron Age," 74, 76. 
12 Svend Nielsen, "Urban Economy in Southern Scandinavia in the Second Half of the First Millennium AD," in The Scandinavians: From the Vendel Period to the Tenth Century, ed. Judith Jesch (Woodbridge: Boydell, 2002), 185.

13 Lotte Hedeager, Iron Age Myth and Materiality: An Archaeology of Scandinavia AD 400-1000 (London: Routledge, 2011), 164.

14 Jørgen Ilkjær, Illerup Ådal: Archaeology as a Magic Mirror (Højbjerg: Moesgård Museum, 2002), 77.

15 Thomas Green, Trade, Gift-giving and Romanitas: A Comparison of the Use of Roman Imports in Western Britain and Southern Scandinavia (Louth: Lindes Press, 2009), 9.

16 Price, Ancient Scandinavia, 269-287.

17 Axboe, "Kingdom of Denmark," 112.

18 His ita gestis, Dani cum rege suo nomen Chlochilaichum evectu navali per mare Gallias appetunt. Gregory of Tours, "Historiarum libri X," in MGH SRM I-I, ed. Bruno Krusch and Wilhelm Levison (Hannover: Hahn, 1951), 99. See also Section V.1.1, esp. note 5 .

19 Ibi tamen, ut fertur, regnabat Ongendus, homo omni fera crudelior et omni lapide durior [...]. Alcuin, "Vita Willibrordi archiepiscopi Traiectensis," in MGH SRM VII, ed. Bruno Krusch and W. Levison (Hannover: Hahn, 1920), 123. Translation from C.H.Talbot, trans., "The Life of Saint Willibrord," in Soldiers of Christ: Saints and Saints' Lives from Late Antiquity and the Early Middle Ages, ed. Thomas Noble and Thomas Head (University Park, PA: Pennsylvania State University Press, 1995), 198.

20 [...] ferocissimos Danorum populos iter euangelizandi convertit. Alcuin, "VW," 123.

21 Ulf Näsman, "Raids, Migrations, and Kingdoms - the Danish Case," Acta Archaeologica 71 (2000): 5.An extensive survey of the late Germanic Iron Age ornamentation styles of southern Scandinavia is found in Mogens Ørsnes, "Südskandinavische Ornamentik in der jüngeren germanischen Eisenzeit," Acta Archaeologica 40 (1969): 1-121.

22 Myhre, "The Iron Age," 83-86; Axboe, "Kingdom of Denmark," 114.

23 Anne Nørgård Jørgensen, "Naval Bases in Southern Scandinavia from the 7th to the 12th Century," in Maritime Warfare in Northern Europe: Technology, Organisation, Logistics and Administration 500 BC-1500 AD, ed. Anne Nørgård Jørgensen et al. (Copenhagen: National Museum of Denmark, 2002), 153.

24 Flemming Rieck, "Aspects of Coastal Defence in Denmark," in Aspects of Maritime Scandinavia $A D$ 200-1200, ed. Ole Crumlin-Pedersen (Roskilde: Viking Ship Museum, 1991), 94;Anne Nørgård Jørgensen, "Danish Naval Complexes in the Late Iron Age and Viking Age: The Gudsø Vig Barrage in Perspective," in The Martial Society: Aspects of Warriors, Fortifications and Social Change in Scandinavia, ed. Lena Holmquist Olausson and Michael Olausson (Stockholm: Stockholm University, 2009), 87-88.

25 Astrid Tummuscheit and Frauke Witte, "The Danevirke in the Light of Recent Excavations," in The Fortified Viking Age, ed. Jesper Hansen and Mette Bruus (Odense: University Press of Southern Denmark, 2018), 70-72.

26 Andres Siegfried Dobat, "Danevirke Revisited: An Investigation into Military and Socio-Political Organisation in South Scandinavia (c. AD 700 to 1100)," Medieval Archaeology 52, no. 1 (2008): 39, 55-56.

27 Thurston, Landscapes of Power, 150.

28 The use of Nordmanni and its various synonyms and derivatives by overseas authors is discussed in Ildar H. Garipzanov, "Frontier Identities: Carolingian Frontier and the Gens Danorum," in Franks, Northmen, and Slavs: Identities and State Formation in Early Medieval Europe, ed. Ildar H. Garipzanov, Patrick Geary, and Przemyslaw 
Urbanczyk (Turnhout: Brepols, 2008), 115-125; David Dumville, "Vikings in Insular Chronicling," in The Viking World, ed. Stefan Brink and Neil Price (London: Routledge, 2008), 354.

29 Hunc multae circumsedent nationes; Danes siquidem ac Sueones, quos Nordmannos vocamus et septentrionale litus et omnes in eo insulas tenent. 'Many peoples live around [the Baltic Sea]. The Danes and Swedes, whom we call Northmen, hold the northern shore and the islands along it.' Einhard, Vita Karoli magni, ed. G. Waitz, MGH SRG XXV (Hannover: Hahn, 1911), 15. Translation from Thomas Noble, trans., "The Life of Charles the Emperor," in Charlemagne and Louis the Pious (University Park, PA: Penn State University Press, 2009), 32. See also Garipzanov, "Frontier Identities," 118-119.

30 Rimbert, Vita Anskarii, ed. G. Waitz, MGH SRG LV (Hannover: Hahn, 1884), 18, 36. A number of alleged ninth and early tenth-century papal charters referencing Norwegians are considered to have been falsified at later points in time (i.e., during the eleventh and twelfth centuries). See Wolfgang Seegrün, Das Erzbistum Hamburg in seinen älteren Papsturkunden (Cologne: Böhlau, 1976), 101-111; Eric Knibbs, Ansgar, Rimbert and the Forged Foundations of Hamburg-Bremen (Farnham: Ashgate, 2011), 104.

31 Johannes Fried, "Gens und Regnum: Wahrnehmungs- und Deutungskategorien politischen Wandels im früheren Mittelalter," in Sozialer Wandel im Mittelalter:Wahrnehmungsformen, Erklärungsmuster, Regelungsmechanismen, ed. Jürgen Miethke and Klaus Schreiner (Sigmaringen: Thorbecke, 1993), 78-79.

32 Janet Bately, ed., The Old English Orosius (Oxford: Oxford University Press, 1980), 16.

33 K.L. Maund, “'A Turmoil of Warring Princes': Political Leadership in NinthCentury Denmark," Haskins Society Journal 6 (1994): 46-47; Garipzanov, "Frontier Identities," 113-114.

34 Roger Collins, Charlemagne (Toronto: University of Toronto Press, 1998), 43.

35 Nam cuncti ad eum venerunt praeter Widokindum, unum ex primoribus Westfalaorum, qui multorum sibi facinorum conscius et ob id regem veritus ad Sigifridum Danorum regem profugerat. This particular passage only features in the revised version of the $A R F$ (Class E), whereas prior texts are more concise, merely mentioning an escape to partes Nordmanniae. Both versions are found in Georg Heinrich Pertz, ed., Annales regni Francorum et annales qui dicuntur Einhardi, MGH SRG VI (Hannover: Hahn, 1895), 48-49. Translation from Bernhard Walter Scholz, trans., Carolingian Chronicles: Royal Frankish Annals and Nithard's Histories (Ann Arbor: University of Michigan Press, 1972), 55, 184.

36 Aut si pompiferi Sigifrit perpendere vultum, / impia pestiferi nunc regni sceptra tenentis [...]. Ernst Dümmler, ed. "Pauli et Petri diaconorum carmina," in MGH Poetae I (Berlin: Weidmann, 1881), 51. Translation from Anders Winroth, The Conversion of Scandinavia: Vikings, Merchants, and Missionaries in the Remaking of Northern Europe (New Haven: Yale University Press, 2012), 13.

37 Kurze, $A R F, 60$.

38 [...] trucidantes cum caeteris et Godescalcum regis legatum, quem ille ante paucos dies ad Sigifridum regem Danorum miserat. Is cum eodem tempore reverteretur, ab huius seditionis auctoribus interceptus atque occisus est. Ibid., 103.

39 Maund, "Turmoil of Warring Princes," 34.

40 Kurze, $A R F, 110$. Early Carolingian countermeasures are discussed in Section V.3.

41 Eodem tempore Godofridus [...] venit cum classe sua necnon omni equitatu regni sui $[\ldots]$. Ibid., 118. Translation from Scholz, Carolingian Chronicles, 83.

42 Kurze, ARF, 125-126. 
43 Ibi per aliquot dies moratus limitem regni sui, qui Saxoniam respicit, vallo munire constituit, eo modo, ut ab orientali maris sinu, quem illi Ostarsalt dicunt, usque ad occidentalem oceanum totam Egidorae fluminis aquilonalem ripam munimentum valli praetexeret, una tantum porta dimissa, per quam carra et equites emitti et recipi potuissent. Ibid., 126. Translation from Scholz, Carolingian Chronicles, 88-89.

44 Dobat, "Danevirke Revisited," 41.

45 Kurze, $A R F, 128,131$; Einhard, VKM, 17. The meeting at Beidenfleth was called by Godfrid, who sought to clear his name of any wrongdoings - insisting that the Obodrites were the initial aggressors of the conflict.

$46[\ldots]$ totasque Frisiaco litori adiacentes insulas esse vastatas iamque exercitum illum in continenti esse ternaque proelia cum Frisonibus commisisse Danosque victores tributum victis inposuisse et vectigalis nomine centum libras argenti a Frisonibus iam esse solutas, regem vero Godofridum domi esse. Kurze, ARF, 131. Translation from Scholz, Carolingian Chronicles, 91-92.

47 Nam rex ille vanissima spe victoriae inflatus acie se cum imperatore congredi velle iactabat. [...] Godofridum regem a quodam suo satellite interfectum [...]. Kurze, $A R F, 131$. Translation in Scholz, Carolingian Chronicles, 92. Notker of St. Gall, in a potential flight of fancy, adds that one of Godfrid's sons was responsible for the murder: Cum vero falconem suum de aneta vellet extrahere, consecutus eum filius suus, cuius nuperrime matrem reliquit et alteram super eam duxit uxorem, per medium divisit. "When he was calling his falcon off a duck, his son, whose mother Godfred had recently abandoned to take another wife instead of her, pursued him and cut him in two.' Notker, Gesta Karoli magni imperatoris, ed. Hans Haefele, MGH SRG NS XII (Berlin: Weidmann, 1959), 76. Translation from Thomas Noble, trans., "The Deeds of Emperor Charles the Great," in Charlemagne and Louis the Pious (University Park, PA: Pennsylvania State University Press, 2009), 107.

48 Kurze, ARF, 133-134.

$49[\ldots]$ datis vicissim secundum ritum ac morem suum sacramentis pax confirmatur. Ibid., 134. Translation from Scholz, Carolingian Chronicles, 93.

50 See, for example, Alfred P. Smyth, Scandinavian Kings in the British Isles: 850-880 (Oxford: Oxford University Press, 1977), 30.

51 Thurston, Landscapes of Power, 67; Peter Sawyer, Kings and Vikings: Scandinavia and Europe AD 700-1100 (Abingdon: Routledge, 1984), 53.

52 Kurze, $A R F, 136$. Even though the word used by the annalist to denote this familial relationship - nepos-commonly signifies 'nephew', other possible translations include various lineal or collateral male descendants, including 'grandson' and 'cousin'. See discussions in Simon Coupland, "From Poachers to Gamekeepers: Scandinavian Warlords and Carolingian Kings," Early Medieval Europe 7, no. 1 (1998): 106n; Maund, "Turmoil of Warring Princes," 36n.

53 [...] trans Albim fluvium ad confinia Nordmannorum [...]. Kurze, ARF, 138.

54 Qui tamen eo tempore domi non erant, sed ad Westarfoldam cum exercitu profecti, quae regio ultima regni eorum inter septentrionem et occidentem sita, contra aquilonem Brittaniae summitatem rescipit, cuius principes ac populus eis subici recusabant. Ibid. Translation from Scholz, Carolingian Chronicles, 96. Principes (sg. princeps) has been left untranslated, as present-day English 'princes' mischaracterises the political status of these elites.

55 Kurze, $A R F, 138-139$. According to the Chronicon Moissiacense, Hemming, another sibling, was likewise expatriated. See Georg Heinrich Pertz, ed., "Chronicon Moissiacense," in MGH SS I (Hannover: Hahn, 1826), 311. 
56 Maund, "Turmoil of Warring Princes," 38; Søren Sindbæk, "The Lands of Denemearce: Cultural Differences and Social Networks of the Viking Age in South Scandinavia," Viking and Medieval Scandinavia 4 (2008): 199-200. The semicontemporary $V A$ mentions a King Bjorn as ruling in Sweden at this time. Rimbert, $V A, 32$.

57 Kurze, $A R F, 141$. The eleventh-century ecclesiastic Adam of Bremen instead claims that Reginfrid was driven away by Harald, and had resorted to a life of 'piracy'. See Adam, "Gesta Hammenburgensis ecclesiae pontificum," in MGH SS VII, ed. Georg Heinrich Pertz (Hannover: Hahn, 1846), 291.

58 Quo facto Herioldus rebus suis diffidens ad imperatorem venit et se in manus illius commendavit [...]. Kurze, ARF, 141. Translation from Scholz, Carolingian Chronicles, 99.

$59[\ldots]$ filii Godofridi $[. .$.$] in insula quadam tribus milibus a continenti separata residebat, cum$ eis congredi non auderent, vastatis circumquaque vicinis pagis et acceptis popularium obsidibus [...] ad imperatorem in Saxoniam reversi sunt. Ipse enim tunc temporis in loco, qui dicitur Padrebrunno, generalem populi sui conventum habebat. Kurze, ARF, 142. Translation from Scholz, Carolingian Chronicles, 99. The island in question is believed to be Funen, potentially representing a principal seat of Danish kingship at the time. See Garipzanov, "Frontier Identities," 133.

60 The initial appeal dates to 817, whilst the reconciliation took place two years later. Only two of the sons of Godfrid seem to have backed the agreement, whilst another two were apparently banished. Kurze, $A R F, 145,152$.

61 Harald's baptism in 826 is described in detail by numerous sources, including the Annales regni Francorum, Annales Fuldenses, Annales Xantenses, Ermold's In honorem Hludowici Caesaris, Thegan's Vita Hludowici imperatoris and Rimbert's Vita Anskarii. See also Section V.1.3.

62 Kurze, $A R F, 173$.

63 Ibid., 175. At a later point in time, Harald seems to have been branded a traitor and killed by Danish elites. His death is recorded for 852. See Friedrich Kurze, ed., Annales Fuldenses, MGH SR GVII (Hannover: Hahn, 1891), 41-42.

64 Maund, "Turmoil of Warring Princes," 37.

65 For the assembly, see Kurze, $A R F, 178$. The renewed treaty was ratified at Thionville in 831. See G. Waitz, ed., Annales Bertiniani, MGH SR GV (Hannover: Hahn, 1883), 3. The $V A$ describes Horik as sole ruler of the Danish kingdom, whilst the fate of his remaining brothers is unknown. See Rimbert, $V A, 52$.

66 Ubi etiam missi Horich venientes, pyratarum in nostros fines dudum irruentium maximos a se ob imperatoris fidelitatem captos atque interfici iussos retulerunt, petentes insuper dari sibi Frisianos atque Abodritos. Waitz, AB, 16. Translation from Nelson, Annals of St. Bertin, 40. The same entry goes on to confirm that the Obodrite territories had been restored to Carolingian dependency some time before.

67 Waitz, $A B, 23$.

68 Nortmannorum rex Oricus sexcentas naves per Albim fluvium in Germanniam adversus Hludowicum dirigit. Quibus Saxones occurrentes, commisso praelio [...] victores efficiuntur. Unde digressi, Sclavorum quandam impetunt et capiunt civitatem. Ibid., 32. Translation from Nelson, Annals of St. Bertin, 61. The Annales Fuldenses name Hamburg as the civitas in question. Kurze, $A F, 35$. The amount of ships mentioned is considered to be highly exaggerated.

69 The envoys were dispatched in 847; see Waitz, $A B, 35$.

70 Aliquotiens namque regia etiam legatione ad eum mittebatur, et quae ad foedera pacis et utriusque regni utilitatem pertinebant strenue et fideliter peragebat. 'On several occasions 
[Anskar] was sent to [Horik] as an ambassador of the king and sought strenuously and faithfully to bring about a peace that should be advantageous to either kingdom.' Rimbert, VA, 52.Translation from Charles H. Robinson, trans., Anskar: the Apostle of the North (London: SPG, 1921), 82.

71 Waitz, $A B, 38$.

72 Dani intestino inter se praelio dimicantes, adeo tridui concertatione obstinatissima bachati sunt [...]. Ibid., 45. Translation from Nelson, Annals of St. Bertin, 80.

73 Kurze, $A F, 44-45$. The same passage asserts that Horik had previously exiled Gudurm, compelling the latter to take up piratico more ('a piratical way of life').

74 Waitz, $A B, 45$.

75 Roric Nordmannus [...] classem duxit in fines Danorum et consentiente Horico Danorum rege partem regni, quae est inter mare et Egidoram, cum sociis suis possedit. Kurze, AF, 47. Translation from Reuter, Annals of Fulda, 39. For Rorik's benefice, see SectionVI.4.2.1.

76 Desine ergo idola colere, et daemonibus iam servire desiste. Jacques-Paul Migne, ed., "Nicolai papae I: Epistolæ et decreta," in PL CXIX (Montrouge: Migne, 1852), cols. 879-880. The church at Ribe is mentioned in Rimbert, VA, 64. Adam of Bremen also believed Horik II to be the surviving boy mentioned by the $A F$ for 854 (note 73). See Adam, "Gesta," 34.

77 Kurze, $A F, 78-79$; Adam, “Gesta,” 298.

78 Although unsubstantiated, King Sigfrid has previously been associated with contemporary namesakes active around the Frankish realm. See, for example, Section VI.4 and Maund, "Turmoil of Warring Princes," 43-44.

79 Post Olaph [...] Sueonum principem, qui regnavit in Dania cum filiis suis, ponitur in locum eius Sigerich. Adam, "Gesta," 303. Translation from Francis Tschan, trans., History of the Archbishops of Hamburg-Bremen, 2nd ed. (New York: Columbia University Press, 2002), 47.

80 Tanti autem reges, immo tyranni Danorum, utrum simul aliqui regnaverint, an alter post alterum brevi tempore vixerit, incertum est. 'How many Danish kings, or rather tyrants, there were indeed, and whether some of them ruled at the same time or lived for a short time one after the other, is uncertain.' Adam, "Gesta," 303. Translation from Tschan, History of the Archbishops, 47.

81 Ásfrídr gerði kuml pessi, dóttir Óđinkárs, ept Sigtrygg konung, son sinn ok Gnúpu. Gormr reist rúnar. From Samnordisk Runtextdatabas (Uppsala University, 2014), DR4.

82 Widukind, Rerum gestarum Saxonicarum, ed. G. Waitz and K.A. Kehr, MGH SRG LX (Hannover: Hahn, 1935), 59.

83 [...] sá Haraldr er sér vann Danmôrk, alla ok Norveg, ok dani gerði kristna. From Samnordisk Runtextdatabas, DR42. Harald's conversion of Denmark is corroborated by the contemporary Vita Brunonis, as well as Widukind of Corvey. See Ruotger, Vita Brunonis archiepiscopi Coloniensis, MGH SRG NS X (Weimar: Böhlau, 1951), 42-43; Widukind, Gestarum Saxonicarum, 140-141.

84 Maund, “Turmoil of Warring Princes," 35.

85 Garipzanov, "Frontier Identities," 142.

86 Bjørn Myhre,"The EarlyViking Age in Norway," Acta Archaeologica 71 (2000): 43-44.

87 Chris Wickham, Framing the Early Middle Ages (Oxford: Oxford University Press, 2005), 367.

88 Peter Heather, Empires and Barbarians (London: Pan Books, 2009), 497-514.

89 James H. Barrett, "What Caused the Viking Age?," Antiquity 82 (2008): 677-679.

90 Søren Sindbæk, "Silver Economies and Social Ties: Long-Distance Interaction, Long-Term Investments - and Why the Viking Age Happened," in Silver Economies, Monetisation and Society in Scandinavia, AD 800-1100, ed. James Graham-Campbell, 
Søren Sindbæk, and Gareth Williams (Aarhus: Aarhus University Press, 2011), 4647, 56-57, 59; Steven Ashby, "What Really Caused the Viking Age? The Social Content of Raiding and Exploration," Archaeological Dialogues 22 (2015): 93-94, 101.

91 Williams, "Raiding and Warfare," 196; Guy Halsall, Warfare and Society in the Barbarian West, 450-900 (London: Routledge, 2003), 106.

92 Peter Pentz, "Ships \& the Vikings," in Vikings: Life and Legend, ed. Gareth Williams, Peter Pentz, and Matthias Wemhoff (London: British Museum Press, 2014), 206. See also Section VI.1.1.1.

93 See, for example, Anders Winroth, The Age of the Vikings (Princeton: Princeton University Press, 2014), 51; Richard Hall, Exploring the World of the Vikings (London: Thames \& Hudson, 2007), 67-73.

94 'Necessary instruments [sailors] are, and Agents of maine importance in that hydrarchy wherin they live [...].' From Richard Braithwaite, Whimzies: or, a New Cast of Characters (London: Felix Kingston, 1631), 144. See also Neil Price, "Ship-Men and Slaughter-Wolves: Pirate Polities in the Viking Age," in Persistent Piracy: Maritime Violence and State-Formation in Global Historical Perspective, ed. Stefan Eklöf Amirell and Leos Müller (London: Macmillan, 2014), 56.

95 Peter Linebaugh and Marcus Rediker, The Many-Headed Hydra: Sailors, Slaves, Commoners, and the Hidden History of the Revolutionary Atlantic (Boston: Beacon Press, 2000), 156, 162.

96 Ibid., 154-167.

97 Price, "Ship-Men," 56-59; Price, "Pirates of the North Sea?," 156-158.

98 Price, "Ship-Men," 56; Price, "Pirates of the North Sea?," 163.

99 Niels Lund, "Allies of God or Man: The Viking Expansion in a European Perspective," Viator 20 (1989), 52-53; Ben Raffield et al., "Ingroup Identification, Identity Fusion and the Formation of Viking War Bands," World Archaeology 48, no. 1 (2016); Charlotte Hedenstierna-Jonson, "Social and Political Formations in the Scandinavian Areas, 8th-10th Century: The Martial Perspective," Territorio, Sociedad y Poder 2 (2009): 97; Judith Jesch, Ships and Men in the Late Viking Age: The Vocabulary of Runic Inscriptions and Skaldic Verse (Woodbridge: Boydell, 2001), 187-188. The Annales Bertiniani mention a viking host dispersing into individual sodalitates to overwinter along the Seine in 861. See Section VI.1.1.1 and Waitz, $A B, 56$.

100 Price, “Ship-Men," 58.

101 Waitz, $A B, 67,107$. See also Flodoard, "Historia Remensis ecclesiae," in MGH SS XIII, ed. J. Heller and G. Waitz (Hannover: Hahn, 1881), 563.

102 McLeod, Scandinavian Settlement, 133-136. See also Judith Jesch, "Vikings on the European Continent in the Late Viking Age," in Scandinavia and Europe 8001350: Contact, Conflict, and Coexistence, ed. Jonathan Adams and Katherine Holman (Turnhout: Brepols, 2004), 257-258.

103 See, for example, Kurze, $A R F$, 169; Waitz, AB, 58; Abbo, BPU, 34, 82; Friedrich Kurze, ed., Reginonis abbatis Prumiensis chronicon, MGH SRG L (Hannover: Hahn, 1890), 106.

104 Raffield et al., "Ingroup Identification," 5-10. See also Raffield, "Bands of Brothers," 320.

105 Price, "Ship-Men," 62; Price, "Pirates of the North Sea?," 167.

106 Waitz, $A B, 79$; Kurze, $A F, 120-121$;Abbo, BPU, 58, 78; Michel Sot, Guy Lobrichon, and Monique Goullet, eds., Les Gestes des évêques d'Auxerre, vol. I (Paris: Les Belles Lettres, 2002), 195. 
107 Julian Richards et al., "Excavations at the Viking Barrow Cemetery at Heath Wood, Ingleby, Derbyshire," The Antiquaries Journal 84 (2004): 105-108.

108 Simon Coupland, "The Vikings in Francia and Anglo-Saxon England to 911," in The New Cambridge Medieval History, ed. Rosamond McKitterick, vol. II (Cambridge: Cambridge University Press, 1995), 190-201.

109 Waitz, $A B, 33$; Kurze, RP, 138.

110 See, for example, Wormald, "Viking Studies," 137; Halsall, Warfare and Society, 113. These fleet dynamics are more thoroughly discussed in Section VI.1.1.1.

111 The characteristics and whereabouts of these encampments are considered in Section VI.2 and its subsections.

112 Shane McLeod, "Feeding the micel here in England, c. 865-878," Journal of the Australian Early Medieval Association 2 (2006): 141-156.

113 Williams, "Raiding and Warfare," 197-199; Clare Downham, "Viking Ethnicities: A Historiographic Overview," History Compass 10 (2012): 6. By and large, the presumed interdependence between hydrarchs and their respective followings may well be characterised as a type of Gefolgschaft, as discussed in Jos Bazelmans, By Weapons Made Worthy: Lords, Retainers and their Relationship in Beowulf (Amsterdam: Amsterdam University Press, 1999), 4-15.

114 Price, "Ship-Men," 57.

115 Coupland, "Poachers to Gamekeepers," 93-101. Another hydrarch, Rodulf, is likewise described as being de regio genere, 'of royal stock'. Kurze, $A F, 80$.

116 See Section II.1.2 above. Waitz, $A B, 12,16$.

117 Hlotharius, Hlodowicus et Karolus legatos ad Oric Danorum regem destinant, mandates, ut suos christianorum infestationibus cohiberet. Ibid., 35. Translation from Nelson, Annals of St. Bertin, 65.

118 Myhre, "Beginning of the Viking Age," 192.

119 See Sections II.1.2,V.1.3, and VI.4 for these particular leaders.

120 Marcel Mauss, The Gift: The Form and Reason for Exchange in Archaic Societies, trans. W.D. Halls (London: Routledge, 1990), 3; Christopher Tilley, An Ethnography of the Neolithic: Early Prehistoric Societies in Southern Scandinavia (Cambridge: Cambridge University Press, 2003), 101. For a more panoramic, anthropologically focussed discussion on the study of gift exchange, status, and societal hierarchy in the preand early historic Germanic world, see Bazelmans, By Weapons Made Worthy, esp. Chapters 5 and 6.

121 Hedeager, "Scandinavia before the Viking Age," 15.

122 Price, Ancient Scandinavia, 266-276; Dagfinn Skre, "The Development of Urbanism in Scandinavia," in The Viking World, ed. Stefan Brink and Neil Price (London: Routledge, 2008), 86-87.

123 Nielsen, "Urban Economy," 178.

124 John Ljungkvist, "Continental Imports to Scandinavia: Patterns and Changes between AD 400 and 800," in Foreigners in Early Medieval Europe, ed. Dieter Quast (Mainz: Römisch-Germanischen Zentralmuseum, 2009), 28-47. Finds of seventh and eighth-century reticella glass of a presumed Anglo-Irish provenance have been made in a number of late Iron Age settlements in southern Scandinavia. See Ulf Näsman, "Vendel Period Glass from Eketorp-II, Öland, Sweden," Acta Archaeologica 55 (1984): 81, 91.

125 This shift in economic focus has been attributed to the contemporary formation of Slavic and Avar polities across eastern Europe, blocking previously established trade routes. See Ulf Näsman, "The Justinianic Era of South Scandinavia: An 
ArchaeologicalView," in The Sixth Century: Production, Distribution and Demand, ed. Richard Hodges and William Bowden (Leiden: Brill, 1998), 271.

126 Christopher Loveluck, Northwest Europe in the Early Middle Ages, c. AD 600-1150: A Comparative Archaeology (Cambridge: Cambridge University Press, 2013), 182-183.

127 Myhre, "The Iron Age," 91-92.

128 Dagfinn Skre, "Post-Substantivist Towns and Trade AD 600-1000," in Means of Exchange: Dealing with Silver in the Viking Age, ed. Dagfinn Skre (Aarhus: Aarhus University Press, 2007), 327.

129 Lars Jørgensen, "Manor and Market at Lake Tissø in the Sixth to Eleventh Centuries: The Danish 'Productive' Sites," in Markets in Early Medieval Europe: Trading and "Productive" Sites, 650-850, ed. Tim Pestell and Katharina Ulmschneider (Macclesfield: Windgather Press, 2000), 203.

130 Dagfinn Skre, "Markets, Towns and Currencies in Scandinavia ca. AD 200-1000," in From One Sea to Another: Trading Places in the European and Mediterranean Early Middle Ages, ed. Sauro Gelichi and Richard Hodges (Turnhout: Brepols, 2012), 55.

131 Richard Hodges, Dark Age Economics: The Origins of Towns and Trade AD 600-1000 (London: Duckworth, 1982), 47-86; Johan Callmer, "Urbanisation in Northern and Eastern Europe, ca. AD 700-1100," in Post-Roman Towns, Trade and Settlement in Europe and Byzantium: The Heirs of the Roman West, ed. Joachim Henning (Berlin: de Gruyter, 2007), 239; Wickham, Early Middle Ages, 685-686.

132 Christer Westerdahl, "From Land to Sea, From Sea to Land: On Transport Zones, Borders and Human Space," in Down the River to the Sea, ed. Jerzy Litwin (Gdańsk: Polish Maritime Museum, 2000), 14-16.

133 Wickham, Early Middle Ages, 682.

134 Lebecq, "New Wiks or Emporia," 12-13.

135 Wickham, Early Middle Ages, 682-683.

136 Skre, "Urbanism," 84, 91.

137 Claus Feveile, "Ribe on the North Side of the River, 8th -12th Century: Overview and Interpretation," in Det celdste Ribe: Udgravninger pa nordsiden af Ribe $\AA 1984$ 2000, ed. Claus Feveile, vol. 1 (Højbjerg: Jysk Arkæologisk Selskab, 2006), 78; Lars Pilø, "The Settlement: Character, Structures and Features," in Kaupang in Skiringssal, ed. Dagfinn Skre (Aarhus: Aarhus University Press, 2007), 191-195; Skre, "Urbanism," 84-85.

138 Søren Sindbæk, "Local and Long-Distance Exchange," in The Viking World, ed. Stefan Brink and Neil Price (London: Routledge, 2008), 154; Skre, "Markets, Towns and Currencies," 57.

139 Skre, "Urbanism," 84, 87; Charlotta Hillerdal, "Early Urbanism in Scandinavia," in The Urban Mind: Cultural and Environmental Dynamics, ed. Paul J.J. Sinclair et al. (Uppsala: Uppsala University, 2010), 501-504.

140 Price, Ancient Scandinavia, 341, 345; Myhre, "The Iron Age," 87; Axboe, "Kingdom of Denmark," 114.

141 Rimbert, $V A, 32,56$.

142 Costambeys, Innes, and MacLean, Carolingian World, 355.

143 Dagfinn Skre, "Dealing with Silver: Economic Agency in South-Western Scandinavia AD 600-1000," in Means of Exchange: Dealing with Silver in the Viking Age, ed. Dagfinn Skre (Aarhus: Aarhus University Press, 2007), 346. The perceived distinction between contemporary economies based on gift exchange and commodity exchange are discussed in Bazelmans, By Weapons Made Worthy, 13-18. 
144 Søren Sindbæk, "Networks and Nodal Points: The Emergence of Towns in Early Viking Age Scandinavia," Antiquity 81 (2007): 126.

145 Hillerdal, "Urbanism in Scandinavia," 509.

146 Hans Andersson, "Urbanisation," in The Cambridge History of Scandinavia, ed. Knut Helle, vol. I (Cambridge: Cambridge University Press, 2003), 317.

147 Price, Ancient Scandinavia, 204-205.

148 Skre, "Dealing with Silver," 344-346.

149 Dagfinn Skre, "Money and Trade in Viking-Age Scandinavia," in Economies, Monetisation and Society in the West Slavic Lands 800-1200 AD, ed. Mateusz Bogucki and Marian Rębkowski (Szczecin: Szczecin University, 2013), 79.

150 Christoph Kilger, "Wholeness and Holiness: Counting, Weighing and Valuing Silver in the Early Viking Period," in Means of Exchange: Dealing with Silver in the Viking Age, ed. Dagfinn Skre (Aarhus: Aarhus University Press, 2007), 278.

151 Gareth Williams, "Kingship, Christianity and Coinage: Monetary and Political Perspectives on Silver Economy in theViking Age," in Silver Economy in the Viking Age, ed. James Graham-Campbell and Gareth Williams (Walnut Creek: Left Coast Press, 2007), 181-183. See also Sindbæk, "Silver Economies and Social Ties," 42.

152 Claus Feveile, "Series X and Coin Circulation in Ribe," in Studies in Early Medieval Coinage I: Two Decades of Discovery, ed. Tony Abramson (Woodbridge: Boydell, 2008), 53, 65.

153 Brita Malmer, "South Scandinavian Coinage in the Ninth Century," in Silver Economy in the Viking Age, ed.James Graham-Campbell and Gareth Williams (Walnut Creek: Left Coast Press, 2007), 22-23; Garipzanov, “Frontier Identities," 139.

154 Williams, "Kingship, Christianity and Coinage,” 188.

155 Simon Franklin and Jonathan Shepard, The Emergence of Rus': 750-1200 (Harlow: Longman, 1996), 15.

156 Duczko, Viking Rus', 66.

157 Franklin and Shepard, The Emergence of Rus': 750-1200,14-15, 20.

158 Christoph Kilger, "Kaupang from Afar: Aspects of the Interpretation of Dirham Finds in Northern and Eastern Europe between the Late 8th and Early 10th Centuries," in Means of Exchange: Dealing with Silver in the Viking Age, ed. Dagfinn Skre (Aarhus: Aarhus University Press, 2007), 200-201, 216-217; Thomas S. Noonan, "The Vikings in the East: Coins and Commerce," in Developments around the Baltic and the North Sea in the Viking Age, ed. Björn Ambrosiani and Helen Clarke (Stockholm: Riksantikvarieämbetet, 1994), 216-219.

159 Franklin and Shepard, The Emergence of Rus': 750-1200, 14; Thomas S. Noonan, "European Russia, c. 500-c. 1050," in The New Cambridge Medieval History, ed. Timothy Reuter, vol. III (Cambridge: Cambridge University Press, 2000), 506.

160 Roman K. Kovalev and Alexis C. Kaelin, "Circulation of Arab Silver in Medieval Afro-Eurasia: Preliminary Observations," History Compass 5, no. 2 (2007): 564566; McCormick, European Economy, 383.

161 Svein H. Gullbekk, "Coinage and Monetary Economies," in The Viking World, ed. Stefan Brink and Neil Price (London: Routledge, 2008), 162.

162 Ingrid Gustin, "Islam, Merchants, or King? - Who Was behind the Manufacture of Viking Age Weights?," in Visions of the Past: Trends and Traditions in Swedish Medieval Archaeology, ed. Hans Andersson and Peter Carelli (Stockholm: Riksantikvarieämbetet, 1997), 164-168. 
163 Kilger, "Kaupang from Afar," 202; Dagfinn Skre, "Commodity Money, Silver and Coinage in Viking-Age Scandinavia," in Silver Economies, Monetisation and Society in Scandinavia, AD 800-1100, ed. James Graham-Campbell, Søren Sindbæk, and Gareth Williams (Aarhus: Aarhus University Press, 2011), 84-85.

164 Kilger, "Kaupang from Afar," 216-227.

165 Rory Naismith, "Islamic Coins from Early Medieval England," Numismatic Chronicle 165 (2005): 205.

166 Birgitta Hårdh, "Hacksilver and Ingots," in Means of Exchange: Dealing with Silver in the Viking Age, ed. Dagfinn Skre (Aarhus: Aarhus University Press, 2007), 104.

167 Kilger, "Kaupang from Afar," 208.

168 Simon Coupland, "Carolingian Coinage and Scandinavian Silver," Nordisk numismatisk arsskrift (1986): 16-17; Janet Nelson, "The Frankish Empire," in The Oxford Illustrated History of the Vikings, ed. Peter Sawyer (Oxford: Oxford University Press, 1997), 37.

169 McCormick, European Economy, 609-612.

170 Dagfinn Skre, "Dark Age Towns: The Kaupang Case - Reply to Przemysław Urbańczyk," Norwegian Archaeological Review 41, no. 2 (2008): 202.

171 Claus Feveile, "Ribe: Emporia and Town in the 8th and 9th Century," in From One Sea to Another: Trading Places in the European and Mediterranean Early Middle Ages, ed. Sauro Gelichi and Richard Hodges (Turnhout: Brepols, 2012), 120.

172 Hillerdal, "Urbanism in Scandinavia," 503; Feveile, "Ribe on the North Side," 87-88.

173 [...] Liopdago Ripensis ecclesiae episcopo [...]. Ludwig Weiland, ed., "Synodus Ingelheimensis," in MGH Const. I (Hannover: Hahn, 1843), 13-14. See also Rimbert, $V A, 64$.

174 Skre, "Dark Age Towns: Reply," 200.

175 Stefan Brink has suggested a possible centre around Vittersøtjønna, a small lake in the centre of Tjølling parish, whilst Dagfinn Skre has pointed to Tønsberg, c. twenty-seven km northeastward. See Stefan Brink, "Skiringssal, Kaupang, Tjølling: The Toponymic Evidence," in Kaupang in Skiringssal, ed. Dagfinn Skre (Aarhus: Aarhus University Press, 2007), 56; Skre, "Urbanism," 85.

176 Johan Callmer, "Urbanization in Scandinavia and the Baltic Region c. AD 7001100: Trading Places, Centres and Early Urban Sites," in Developments around the Baltic and the North Sea in the Viking Age, ed. Björn Ambrosiani and Helen Clarke (Stockholm: Riksantikvarieämbetet, 1994), 72.

177 Skre, "Urbanism," 85.

178 Callmer, "Urbanisation in Northern and Eastern Europe," 244-246.

179 Jonas Ros, "Sigtuna," in The Viking World, ed. Stefan Brink and Neil Price (London: Routledge, 2008), 140-144; Christian Radtke, "Money, Port and Ships from a Schleswig Point of View," in Connected by the Sea: Proceedings of the Tenth International Symposium on Boat and Ship Archaeology, Roskilde 2003, ed. Lucy Blue, Fred Hocker, and Anton Englert (Oxford: Oxbow, 2006), 148-150.

180 Andersson, "Urbanisation," 319.

181 Skre, "Urbanism," 86.

182 Anders Andrén, "State and Towns in the Middle Ages: The Scandinavian Experience," Theory and Society 18, no. 5 (1989): 588-591;Näsman,"Ethnogenesis," 5; Callmer, "Urbanisation in Northern and Eastern Europe," 244.

183 Inge Skovgaard-Petersen, "The Making of the Danish Kingdom," in The Cambridge History of Scandinavia, ed. Knut Helle, vol. I (Cambridge: Cambridge University Press, 2003), 174. 
184 Alexandra Sanmark, "Power and Conversion: A Comparative Study of Christianization in Scandinavia" (PhD Diss., Uppsala University, 2004), 81-82; Hillerdal, "Urbanism in Scandinavia," 519.

185 Nils Hybel and Bjørn Poulsen, The Danish Resources c. 1000-1550: Growth and Recession (Leiden: Brill, 2007), 324.

186 Birgit Sawyer and Peter Sawyer, "Scandinavia Enters Christian Europe," in The Cambridge History of Scandinavia, ed. Knut Helle, vol. I (Cambridge: Cambridge University Press, 2003), 149.

187 The perception that late Viking Age towns may have been calculated imports to Scandinavian society has been increasingly challenged as isolationist. See Hillerdal, "Urbanism in Scandinavia," 502.

1 TON ФРANKON ФIAON EXIC, ГITONA OYK EXIC. Einhard, VKM, 20. Translation from Noble, "Life of Charles," 36.

2 Costambeys, Innes, and MacLean, Carolingian World, 3-4.

3 McKitterick, Frankish Kingdoms, 31; Pierre Riché, The Carolingians: A Family Who Forged Europe (Philadelphia: University of Pennsylvania Press, 1993), 65-68; D.A. Bullough, Carolingian Renewal: Sources and Heritage (Manchester: Manchester University Press, 1991), 124-125. The Carolingians were named for their progenitor, Charles 'Martel' (†741), father to Pippin.

4 Paul Fouracre, "Frankish Gaul to 814," in The New Cambridge Medieval History, ed. Rosamond McKitterick, vol. II (Cambridge: Cambridge University Press, 1995), 99-101.

5 McKitterick, Frankish Kingdoms, 61-63; David Ganz, "Einhard's Charlemagne: The Characterisation of Greatness," in Charlemagne: Empire and Society, ed. Joanna Story (Manchester: Manchester University Press, 2005), 42.

6 Rosamond McKitterick, "The Carolingian Renaissance of Culture and Learning," in Charlemagne: Empire and Society, ed. Joanna Story (Manchester: Manchester University Press, 2005), 153.

7 Kurze, $A R F, 112$.

8 Costambeys, Innes, and MacLean, Carolingian World, 160-165.

9 Timothy Reuter, "The End of Carolingian Military Expansion," in Medieval Polities and Modern Mentalities, ed. Janet L. Nelson (Cambridge: Cambridge University Press, 2006), 251-254; Barbara Yorke, Kings and Kingdoms of Early Anglo-Saxon England (London: Seaby, 1990), 95; Rosamond McKitterick, Charlemagne: The Formation of a European Identity (Cambridge: Cambridge University Press, 2008), 284-287.

10 McKitterick, "Carolingian Renaissance," 153, 156-157.

11 Janet Nelson, "The Frankish Kingdoms, 814-898: The West," in The New Cambridge Medieval History, ed. Rosamond McKitterick, vol. II (Cambridge: Cambridge University Press, 1995), 112.

12 Riché, Carolingians, 146.

13 Costambeys, Innes, and MacLean, Carolingian World, 202-203.

14 Thomas Noble, "The Revolt of King Bernard of Italy in 817: Its Causes and Consequences," Studi Medievali: Serie Terza 15, no. 1 (1974): 315-317.

15 Eric Goldberg, Struggle for Empire: Kingship and Conflict under Louis the German, 817-876 (Ithaca: Cornell University Press, 2006), 59-61. For his earlier indignation at the territorial division, Lothar had been stripped of his co-emperorship and sent to Italy. See Ibid., 59.

16 Janet Nelson, Charles the Bald (London: Longman, 1992), 90-91.

17 Costambeys, Innes, and MacLean, Carolingian World, 219. 
18 Nelson, "Frankish Kingdoms," 118.

19 Goldberg, Struggle for Empire, 92-93.

20 Elina Screen, "The Importance of the Emperor: Lothar I and the Frankish Civil War, 840-843," Early Medieval Europe 12, no. 1 (2003): 33.

21 Riché, Carolingians, 160-165.

22 Ceterae usque ad Hispaniam Karolo cesserunt. Waitz, AB, 30. Translation from Nelson, Annals of St. Bertin, 56.

23 Costambeys, Innes, and MacLean, Carolingian World, 379, 381.

24 Nelson, Charles the Bald, 141-143.

25 Waitz, $A B, 32$.

26 Nelson, "Frankish Kingdoms," 124; Nelson, Charles the Bald, 144; Philip Grierson and Mark Blackburn, European Medieval Coinage I: The Early Middle Ages (5th-10th Centuries) (Cambridge: Cambridge University Press, 1986), 219, 237.

27 Nelson, Charles the Bald, 136-137, 142.

28 Julia Smith, Province and Empire: Brittany and the Carolingians (Cambridge: Cambridge University Press, 1992), 96-97.

$29[\ldots]$ paternae potestatis ditione [...]. Waitz, AB, 41. Translation from Nelson, Annals of St. Bertin, 73. See also Nelson, Charles the Bald, 166.

30 [...] desidia inertiaque Pippini [...]. Waitz, AB, 36. Translation from Nelson, Annals of St. Bertin, 66.

31 Nelson, Charles the Bald, 154-155. Despite obtaining renewed support over the following years - as well as allying himself with viking hosts - Pippin never managed to regain his former prominence. See also Waitz, $A B, 47,67,72$.

$32[\ldots]$ ipse super eos regnum susciperet $[\ldots]$. Kurze, $A F, 43$. Translation from Reuter, Annals of Fulda, 35.

33 Kurze, $A F, 44$.

34 Riché, Carolingians, 184.

35 Nelson, Charles the Bald, 180.

36 Ibid., 181.

37 Costambeys, Innes, and MacLean, Carolingian World, 395; Nelson, Charles the Bald, 188-190.

38 Sed et pene omnes qui nuper a Karolo ad Hludowicum defecerant ad Karolum revertuntur [...]. Waitz, AB, 55. Translation from Nelson, Annals of St. Bertin, 95.

39 Nelson, Charles the Bald, 201-204.

40 Waitz, $A B, 58$. Salomon had conspired to assassinate his predecessor, Erispoe, in 857. See Ibid., 48.

41 Ibid., 59.

42 Riché, Carolingians, 185.

43 Costambeys, Innes, and MacLean, Carolingian World, 399.

44 Nelson, Charles the Bald, 219.

45 Johannes Fried, "The Frankish Kingdoms, 817-911: The East and Middle Kingdoms," in The New Cambridge Medieval History, ed. Rosamond McKitterick, vol. II (Cambridge: Cambridge University Press, 1995), 150; Nelson, Charles the Bald, 221-224.

46 Ibid., 226-230.

47 [...] cum ficta humilitate [...]. Waitz, AB, 117. See also Costambeys, Innes, and MacLean, Carolingian World, 401.

48 McKitterick, Frankish Kingdoms, 180.

49 Nelson, Charles the Bald, 239-241. 
50 Waitz, $A B, 132$.

51 Halsall, Warfare and Society, 189.

52 Nelson, Charles the Bald, 252-253.

53 Riché, Carolingians, 213-216.

54 Ibid., 216.

55 [...] morti subcubuit [...]. Waitz, AB, 152. See also Riché, Carolingians, 216.

56 Simon MacLean, Kingship and Politics in the Late Ninth Century: Charles the Fat and the End of the Carolingian Empire (Cambridge: Cambridge University Press, 2003), 124-125.

57 Costambeys, Innes, and MacLean, Carolingian World, 422-424; Riché, Carolingians, 218-219.

$58[\ldots]$ unumquodque de suis visceribus regem sibi creari $[\ldots]$. Kurze, $R P, 129$.

59 Riché, Carolingians, 237.

60 Nelson, "Frankish Kingdoms," 140.

61 Jean Dunbabin, "West Francia: The Kingdom," in The New Cambridge Medieval History, ed. Timothy Reuter, vol. III (Cambridge: Cambridge University Press, 2000), 378.

62 Riché, Carolingians, 250.

63 Geoffrey Koziol, "Charles the Simple, Robert of Neustria, and the Vexilla of SaintDenis," Early Medieval Europe 14, no. 4 (2006): 357.

64 Dunbabin, “West Francia," 379.

65 McKitterick, Frankish Kingdoms, 310.

66 Jason Glenn, Politics and History in the Tenth Century: The Work and World of Richer of Reims (Cambridge: Cambridge University Press, 2004), 218.

67 Costambeys, Innes, and MacLean, Carolingian World, 432-433.

68 The total population size of Carolingian Europe remains contentious. JeanPierre Devroey, Économie rurale et société dans l'Europe franque (VI $I^{e}-I X^{e}$ siècles): Tome I (Paris: Belin, 2003), 41-42. For population growth, see Verhulst, Carolingian Economy, 25-27.

69 Riché, Carolingians, 131-132.

70 Janet Nelson, "Kingship and Empire in the Carolingian World," in Carolingian Culture: Emulation and Innovation, ed. Rosamund McKitterick (Cambridge: Cambridge University Press, 1994), 71.

71 Rosamond McKitterick has emphasised that an itinerant king need not necessarily have represented itinerant kingship, as the regular business of government was not always contingent on travel. See Rosamond McKitterick, "A King on the Move: The Place of an Itinerant Court in Charlemagne's Government," in Royal Courts in Dynastic States and Empires: A Global Perspective, ed. Jeroen Duindam, Tülay Artan, and Metin Kunt (Leiden: Brill, 2011), 167.

72 Karl Ferdinand Werner, "Hludovicus Augustus: gouverner l'empire chrétien - idées et réalités," in Charlemagne's Heir: New Perspectives on the Reign of Louis the Pious (814840), ed. Peter Godman and Roger Collins (Oxford: Clarendon, 1990), 82-83.

73 Costambeys, Innes, and MacLean, Carolingian World, 179. It was not uncommon for a single count to hold multiple comitatus. See, for example, Richard Barton, Lordship in the County of Maine, c. 890-1160 (Woodbridge: Boydell, 2004), 27.

74 Nelson, Charles the Bald, 51.

75 Constance Bouchard, "The Carolingian Creation of a Model of Patrilineage," in Paradigms and Methods in Early Medieval Studies, ed. Celia Chazelle and Felice Lifshitz (Basingstoke: Palgrave Macmillan, 2007), 147.

76 McKitterick, Frankish Kingdoms, 88. 
77 Karl Ferdinand Werner, "Missus, Marchio, Comes: entre l'administration centrale et l'administration locale de l'empire carolingien," in Histoire comparée de l'administration (IV $V^{e}-X V I I I^{e}$ siècles), ed.W. Paravicini and K.F.Werner (Munich: Artemis, 1980), 195, 213-217. Although Charlemagne seems to have instituted such a marca at the base of the Jutland Peninsula, details concerning its management are few and far between. See Ekkehard Eickhoff, "Maritime Defence of the Carolingian Empire," in Vikings on the Rhine: Recent Research on Early Medieval Relations between the Rhinelands and Scandinavia, ed. Rudolf Simek and Ulrike Engel (Vienna: Fassbaender, 2004), 53.

78 McKitterick, Frankish Kingdoms, 87; Michel Zimmermann, "Western Francia: The Southern Principalities," in The New Cambridge Medieval History, ed. Timothy Reuter, vol. III (Cambridge: Cambridge University Press, 2000), 427. Although $d u x$ and ducatus are commonly translated as 'duke' and 'duchy', these terms tend to evoke anachronistic associations, largely inapplicable to ninth and early tenthcentury institutions. See Reuter, Annals of Fulda, 13.

79 Mayke de Jong, "Ecclesia and the Early Medieval Polity," in Staat im frühen Mittelalter, ed. Helmut Reimitz and Stuart Airlie (Vienna: AASP, 2006), 123; Riché, Carolingians, 289-290.

80 Costambeys, Innes, and MacLean, Carolingian World, 179.

81 Mayke de Jong, "Carolingian Monasticism: The Power of Prayer," in The New Cambridge Medieval History, ed. Rosamond McKitterick, vol. II (Cambridge: Cambridge University Press, 1995), 634-636.

82 Nelson, Charles the Bald, 62; Smith, Province and Empire, 101.

83 McKitterick, Frankish Kingdoms, 93-94. Paul Fouracre characterises them as 'highpowered ombudsmen'. Fouracre, "Frankish Gaul," 106.

84 Janet Nelson, "Dispute Settlement in Carolingian West Francia," in The Settlement of Disputes in Early Medieval Europe, ed. Wendy Davies and Paul Fouracre (Cambridge: Cambridge University Press, 1986), 47-48; Rachel Stone, Morality and Masculinity in the Carolingian Empire (Cambridge: Cambridge University Press, 2011), 170-172.

85 Nelson, Charles the Bald, 52; McKitterick, Frankish Kingdoms, 94; Constance Bouchard, Those of My Blood: Creating Noble Families in Medieval Francia (Philadelphia: University of Pennsylvania Press, 2001), 137.

86 Costambeys, Innes, and MacLean, Carolingian World, 320.

87 Nelson, "Kingship and Empire," 68-69. Capitula could also be drawn up at a ruler's personal behest (i.e. outside the context of these assemblies). See Gerhard Schmitz, "Kapitularien," in Handwörterbuch zur deutschen Rechtsgeschichte, ed. Albrecht Cordes, Heiner Lück, and Dieter Werkmüller, vol. II (Berlin: Schmidt, 2012), col. 1606.

88 Ganshof, Frankish Institutions, 32; McKitterick, Frankish Kingdoms, 87.

89 Patrick Wormald, Legal Culture in the Early Medieval West (London: Hambledon, 1999), 29.

90 François-Louis Ganshof, "The Impact of Charlemagne on the Institutions of the Frankish realm," Speculum 40, no. 1 (1965): 58; Jennifer Davis, Charlemagne's Practice of Empire (Cambridge: Cambridge University Press, 2015), 52. The aforementioned vicarii and centenarii dealt with infractions on a more local scale. See Riché, Carolingians, 127.

91 Yitzak Hen, "Knowledge of Canon Law among Rural Priests: The Evidence of Two Carolingian Manuscripts from around 800," Journal of Theological Studies 50, no. 1 (1999): 129, 132; Rob Meens, “The Frequency and Nature of Early Medieval Penance," in Handling Sin: Confession in the Middle Ages, ed. Peter Biller and A.J. Minnis (York: York Medieval Press, 1998), 47-48. 
92 Halsall, Warfare and Society, 89-93.

93 Ibid., 95.

94 Coupland, "Carolingian Army," 60. The exact numerical contribution of the vassi remains largely unresolved. See, for example, Bernard S. Bachrach, "Military Organization in Aquitaine under the Early Carolingians," Speculum 49 (1974): 32; Halsall, Warfare and Society, 76-77.

$95[\ldots]$ confecta maxime de episcopis [...]. Waitz, AB, 84. Translation from Nelson, Annals of St. Bertin, 136.

$96[\ldots]$ nisi talis regni invasio, quam lantweri dicunt [...] acciderit, ut omnis populus illius regni ad eam repellendam communiter pergat. Alfred Boretius and Victor Krause, eds., "Hlotharii, Hludowici et Karoli conventus apud Marsnam primus," in $M G H$ Capit. II (Hannover: Hahn, 1897), 171.

97 Alfred Boretius and Victor Krause, eds., "Edictum Pistense," in MGH Capit. II (Hannover: Hahn, 1897), 321-322.

98 Costambeys, Innes, and MacLean, Carolingian World, 287-288; Matthew Innes, "People, Places and Power in Carolingian Society," in Topographies of Power in the Early Middle Ages, ed. Mayke de Jong and Frans Theuws (Leiden: Brill, 2001), 409.

99 Loveluck, Northwest Europe, 151.

100 Wickham, Early Middle Ages, 676-678, 681.

101 See, for example, Verhulst, Rise of Cities, 47-59.

102 Bernd Päffgen, "Urban Settlements and Sacral Topography in the Rhineland the Time of the Viking Raids," in Vikings on the Rhine: Recent Research on Early Medieval Relations between the Rhinelands and Scandinavia, ed. Rudolf Simek and Ulrike Engel (Vienna: Fassbaender, 2004), 83; David Nicholas, The Growth of the Medieval City: From Late Antiquity to the Early Fourteenth Century (London: Longman, 1997), 48.

103 Loveluck, Northwest Europe, 330-331.

104 Nelson, Charles the Bald, 50; Nicholas, The Growth of the Medieval City: From Late Antiquity to the Early Fourteenth Century, 48-49; Philippe Depreux, "A la recherche des défenseurs de la cité à l'époque carolingienne," Les petits cahiers d'Anatole 2 (2001): 8-14.

105 Michael Tangl, ed., Sancti Bonifatii et Lulli epistolae, MGH Epp. sel. I (Berlin: Weidmann, 1916), 86-87.

106 Nelson, Charles the Bald, 260-261; Costambeys, Innes, and MacLean, Carolingian World, 425.

107 McKitterick, Frankish Kingdoms, 275.

108 Riché, Carolingians, 250-254, 260-263; David Bates, "West Francia: The Northern Principalities," in The New Cambridge Medieval History, ed.Timothy Reuter, vol. III (Cambridge: Cambridge University Press, 2000), 399.

109 Jean Dunbabin, France in the Making: 843-1180, 2nd ed. (Oxford: Oxford University Press, 2000), 33, 41-42.

110 Janet Nelson, "Kingship and Royal Government," in The New Cambridge Medieval History, ed. Rosamond McKitterick, vol. II (Cambridge: Cambridge University Press, 1995), 386.

111 Verhulst, Carolingian Economy, 32; Jane Martindale, "The Kingdom of Aquitaine and the 'Dissolution of the Carolingian Fisc,'” Francia 11 (1983): 176-191. See also Wolfgang Metz, Das karolingische Reichsgut (Berlin: de Gruyter, 1960). A distribution map of Carolingian villae containing royal residences may be found in Ross Samson, "The Residences of Potentiores in Gaul and Germania in the Fifth to Mid-Ninth Centuries” (PhD Diss., University of Glasgow, 1991), 340-342. 
112 Nelson, "Kingship and Royal Government," 386.

113 Costambeys, Innes, and MacLean, Carolingian World, 317; Ganshof, Frankish Institutions, 50-53.

114 Nelson, Charles the Bald, 191.

115 See, for example, C.H. Lawrence, Medieval Monasticism, 3rd ed. (Harlow: Pearson, 2001), 70; Davis, Charlemagne's Practice of Empire, 226n243.

116 Jacques-Paul Migne, ed., "Caroli calvi epistolae," in PL CXXIV (Montrouge: Migne, 1852), col. 879.

117 Nelson, "Kingship and Royal Government," 390.

118 Bernard S. Bachrach, "Military Lands in Historical Perspective," Haskins Society Journal 9 (1997): 114; Costambeys, Innes, and MacLean, Carolingian World, 317; Janet Nelson, "The Church's Military Service in the Ninth Century: A Contemporary Comparative View?," Studies in Church History 20, no. 1 (1983): 21-22.

119 Adriaan Verhulst, "Economic Organisation," in The New Cambridge Medieval History, ed. Rosamond McKitterick, vol. II (Cambridge: Cambridge University Press, 1995), 483-486; Verhulst, Carolingian Economy, 14-16.

120 Costambeys, Innes, and MacLean, Carolingian World, 252.

121 Nelson, Charles the Bald, 24-25.

122 Verhulst, Carolingian Economy, 43; Alice Rio, Slavery after Rome: 500-1100 (Oxford: Oxford University Press, 2017), 186, 200-201.

123 Verhulst, "Economic Organisation," 500; Walter Janssen, "Gewerbliche Produktion des Mittelalters als Wirtschaftsfaktor im ländlichen Raum," in Das Handwerk in vor- und frühgeschichtlicher Zeit: Archäologische und philologische Beiträge, ed. Herbert Jankuhn et al. (Göttingen: Vandenhoeck \& Ruprecht, 1983), 385-390. By contrast, overall industrial activity in the civitates seems to have decreased during the eighth and ninth centuries. Joachim Henning, "Early European Towns: The Development of the Economy in the Frankish realm between Dynamism and Deceleration AD 500-1100," in Post-Roman Towns, Trade and Settlement in Europe and Byzantium: The Heirs of the Roman West, ed. Joachim Henning (Berlin: de Gruyter, 2007), 13, 16.

124 Verhulst, "Economic Organisation," 505; Loveluck, Northwest Europe, 66-67.

125 Verhulst, Carolingian Economy, 80-82.

126 Devroey, Économie rurale, 131-132.

127 See, for example, Frans Verhaeghe, "Urban Developments in the Age of Charlemagne,"in Charlemagne: Empire and Society, ed.Joanna Story (Manchester: Manchester University Press, 2005), 279; Verhulst, Carolingian Economy, 72-80, 82-84.

128 Stone, Morality and Masculinity in the Carolingian Empire, 235-237; Janssen, "Gewerbliche Produktion," 390-392.

129 Janet Nelson, "Making Ends Meet: Wealth and Poverty in the Carolingian Church," in The Frankish World, 750-900 (London: Hambledon, 1996), 45; Timothy Reuter, “'You Can't Take It with You': Testaments, Hoards, and Moveable Wealth in Europe, 600-1100," in Treasure in the Medieval West, ed. Elizabeth Tyler (York: York Medieval Press, 2000), 12-13.

130 See, for example, Ferdinand Lot, ed., Chronique de l'abbaye de Saint-Riquier (Paris: Picard et Fils, 1894), 86-88; Bernhard Bischoff, ed., Mittelalterliche Schatzverzeichnisse, vol. I (Munich: Prestel, 1967), 36-38, 87-88, 90-91.

131 Wickham, Early Middle Ages, 194-199; Nelson, "Kingship and Royal Government," 385-386.

132 Verhulst, “Economic Organisation,” 504-505. 
133 Verhulst, Carolingian Economy, 93-94.

134 Stéphane Lebecq, "Long Distance Merchants and the Forms of Their Ventures at the Time of the Dorestad Heyday," in In Discussion with the Past, ed. Herbert Sarfatij (Zwolle: SPA, 1999), 235.

135 Wickham, Early Middle Ages, 803.

136 Verhulst, Carolingian Economy, 94.

137 Ibid., 93; Michael McCormick, "New Light on the 'Dark Ages': How the Slave Trade Fuelled the Carolingian Economy," Past and Present 177, no. 1 (2002): 43-46.

138 Verhulst, Carolingian Economy, 93; Laurent Mazet-Harhoff, "The Incursion of the Vikings into the Natural and Cultural Landscape of Upper Normandy," in Viking Trade and Settlement in Continental Western Europe, ed. Iben Skibsted Klæsøe (Copenhagen: Museum Tusculanum Press, 2010), 88-89, 94.

139 Verhulst, Carolingian Economy, 100-102.

140 Ibid., 98; McCormick, European Economy, 698-699. For a contemporary description of riverine grain transport, see Einhard, "Translatio et miracula sanctorum Marcellini et Petri," in MGH SS XV-I, ed. G. Waitz (Hannover: Hahn, 1887), 250.

141 Wickham, Early Middle Ages, 801-802; Verhulst, "Economic Organisation," 500-502.

142 McCormick, European Economy, 699-702.

143 Verhulst, Carolingian Economy, 97.

144 Traute Endemann, Markturkunde und Markt in Frankreich und Burgund vom 9. bis 11. Jahrhundert (Konstanz: Thorbecke, 1964), 32-33, 52; Ludolf Kuchenbuch, Bäuerliche Gesellschaft und Klosterherrschaft im 9. Jahrhundert: Studien zur Sozialstruktur der Familia der Abtei Prüm (Wiesbaden: Steiner, 1978), 304.

145 Stéphane Lebecq, "The Role of the Monasteries in the Systems of Production and Exchange of the Frankish World between the Seventh and the Beginning of the Ninth Century," in The Long Eighth Century: Production, Distribution and Demand, ed. Inge Lyse Hansen and Chris Wickham (Leiden: Brill, 2000), 141; Verhulst, Carolingian Economy, 97.

146 Jean-Pierre Devroey, “Un monastère dans l'économie d'échanges: les services de transport à l'abbaye Saint-Germain-des-Prés au IX ${ }^{\mathrm{e}}$ siècle," Annales: Histoire, Sciences Sociales 39, no. 3 (1984): 571, 577.

147 Scholars like Frans Verhaeghe have proposed that an absence of nearby waterways may have advanced the decline of some Roman civitates, including Tongeren, whose role as bishop's seat was assumed by nearby Maastricht (on the Meuse) during the sixth century. See Frans Verhaeghe, "Continuity and Change: Links between Medieval Towns and the Roman Substratum in Belgium," Studia varia Bruxellensia 2 (1990): 234-236.

148 Verhulst, Carolingian Economy, 109; Lebecq, Marchands, 1983, I:39-40. See also Dirk Jellema, "Frisian Trade in the Dark Ages," Speculum 30, no. 1 (1955): 26.

149 Christopher Loveluck and Dries Tys, "Coastal Societies, Exchange and Identity along the Channel and Southern North Sea Shores of Europe, AD 600-1000," Journal of Maritime Archaeology 1 (2006): 143.

150 See, for example, W.A. van Es and W.J.H.Verwers, Excavations at Dorestad IV: The Settlement on the River Bank Area (Amersfoort: Cultural Heritage Agency, 2015), 187-200;W.A. van Es, "Dorestad Centred," in Medieval Archaeology in the Netherlands, ed. Jan Besteman, J.M. Bos, and H.A. Heidinga (Maastricht: Van Gorcum, 1990), 173-175. 
151 David Hill et al., "Quentovic Defined," Antiquity 64 (1990): 55-58; Janet Nelson, "England and the Continent in the Ninth Century: II, The Vikings and Others," Transactions of the Royal Historical Society 13 (2003): 19-21.

152 Simon Coupland, "Trading Places: Quentovic and Dorestad Reassessed," Early Medieval Europe 11, no. 3 (2002): 214-226; Lebecq, "New Wiks or Emporia," 18.

153 Verhulst, Carolingian Economy, 130; Loveluck and Tys, "Coastal Societies," 146.

154 Loveluck, Northwest Europe, 179; Stéphane Lebecq," Routes of Change: Production and Distribution in the West (5th-8th Century)," in The Transformation of the Roman World: $A D$ 400-900, ed. Leslie Webster and Michelle Brown (London: British Museum Press, 1997), 69, 73.

155 Jan Besteman, "Carolingian Medemblik," Berichten van de Rijksdienst voor het Oudheidkundig Bodemonderzoek 24 (1974): 48, 97-99; C.L.Verkerk, "Het tolsysteem in het mondingsgebied van Rijn, Maas en Schelde tot de elfde eeuw," in Rotterdam Papers, ed. A. Carmiggelt, vol. 7 (Rotterdam: ROB, 1992), 45-46; Caroline Tulp, "Tjitsma, Wijnaldum: An Early Medieval Production Site in the Netherlands," in Markets in Early Medieval Europe: Trading and "Productive" Sites, 650-850, ed. Tim Pestell and Katharina Ulmschneider (Macclesfield: Windgather Press, 2003), 231232; M.F.P. Dijkstra, Rondom de mondingen van Rijn \& Maas (Leiden: Sidestone, 2011), 329-330.

156 Loveluck and Tys, "Coastal Societies," 144-145. See also Pieterjan Deckers, "An Illusory emporium? - Small Trading Places around the Southern North Sea," in Dorestad in an International Framework, ed. Annemarieke Willemsen and Hanneke Kik (Turnhout: Brepols, 2010), 158-167.

157 McCormick, European Economy, 700; Jacques le Maho,"The Fate of the Ports of the Lower Seine Valley at the End of the Ninth Century," in Markets in Early Medieval Europe: Trading and "Productive" Sites, 650-850, ed. Tim Pestell and Katharina Ulmschneider (Macclesfield: Windgather Press, 2003), 235-236, 242-243.

158 Olivier Bruand, "Pénétration et circulation du sel de l'Atlantique en France septentrionale (VIII'-XI ${ }^{\mathrm{e}}$ Siècles)," Annales de Bretagne et des pays de l'Ouest 114, no. 3 (2008): 10 .

159 François-Louis Ganshof, Het tolwezen in het Frankisch rijk onder de Karolingen (Brussels: Paleis der Academiën, 1959), 9-10.

160 Ganshof, Frankish Institutions, 44; McCormick, European Economy, 398.

161 Neil Middleton, "Early Medieval Port Customs, Tolls and Controls on Foreign Trade," Early Medieval Europe 13, no. 4 (2005): 326; Ganshof, Tolwezen in het Frankisch rijk, 21-22.

162 It is not always readily apparent whether the decima implied a proportional (ad valorem) tax rate on merchandise, or a tenth share of this particular sum destined for a local administrative body (with the remainder going to the royal treasury). See Middleton, "Port Customs," 324-326.

163 René Poupardin, ed., Recueil des chartes de l'abbaye de Saint-Germain-des-Prés, vol. I (Paris: Champion, 1909), 29-31.

164 Devroey, Économie rurale, 162; Riché, Carolingians, 322.

165 Mark Blackburn, "Money and Coinage," in The New Cambridge Medieval History, ed. Rosamond McKitterick, vol. II (Cambridge: Cambridge University Press, 1995), 548-549.

166 Verhulst, Carolingian Economy, 117; Simon Coupland, "Charlemagne's Coinage: Ideology and Economy," in Charlemagne: Empire and Society, ed. Joanna Story (Manchester: Manchester University Press, 2005), 218-227. 
167 Ibid., 220.

168 Costambeys, Innes, and MacLean, Carolingian World, 347-348; Nelson, Charles the Bald, 32-33.

169 Blackburn, “Money and Coinage," 551-552.

170 Simon Coupland, “The Coinage of Lothar I (840-855)," Numismatic Chronicle 161 (2001): 191-193; Blackburn, "Money and Coinage," 554-555.

171 Grierson and Blackburn, Medieval Coinage, 536-537; Nelson, Charles the Bald, 31.

172 Philip Grierson, "The 'Gratia Dei Rex' Coinage of Charles the Bald," in Charles the Bald: Court and Kingdom, ed. Margaret Gibson and Janet Nelson (Oxford: BAR, 1981), 41-42.

173 Grierson and Blackburn, Medieval Coinage, 235, 241-243.

174 Ibid., 246.

175 [...] quia locum mercationis ipsa regio indigebat [...]. Heinrich Erhard, ed., Regesta historiae Westfaliae accedit codex diplomaticus, vol. I (Münster: Regensberg, 1847), 8. Translation from Simon Coupland, "Money and Coinage under Louis the Pious," Francia 17, no. 1 (1990): 39.

176 Theodor Schieffer, ed., MGH DD Kar. III: Lotharii I. et Lotharii II. diplomata (Berlin: Weidmann, 1966), 408-409.

177 Nelson, "Kingship and Royal Government," 397.

178 Nelson, Charles the Bald, 34-35.

179 Blackburn, "Money and Coinage," 554.

180 Verhulst, Carolingian Economy, 121.

181 Simon Coupland, "The Use of Coin in the Carolingian Empire in the Ninth Century," in Early Medieval Monetary History, ed. Rory Naismith, Martin Allen, and Elina Screen (Farnham: Ashgate, 2014), 277-279.

182 McCormick, European Economy, 671. During the latter decades of the century, the terminal decline of Dorestad (see Section VI.4.2.1) may have encouraged the expansion of minting in more southern Quentovic, Amiens, and Rouen. See Coupland, “Trading Places: Quentovic and Dorestad Reassessed," 227; Coupland, "Use of Coin," 280.

183 Grierson and Blackburn, Medieval Coinage, 233-234.

184 Ibid., 225-227.

185 Verhulst, Carolingian Economy, 129-130, 133-135.

1 See, for example, Herbert Jankuhn, "Trade and Settlement in Central and Northern Europe up to and during the Viking Period," Journal of the Royal Society of Antiquaries of Ireland 112 (1982): 20-23.

$2[\ldots]$ vendelit eum Lundoniam Freso cuidam [...]. Bede, Ecclesiastical History of the English People, ed. Bertram Colgrave and R. Mynors (Oxford: Clarendon, 1969), 404.

3 Altfrid, "Vita sancti Liudgeri," in MGH SS II, ed. Georg Heinrich Pertz (Hannover: Hahn, 1888), 407.

4 Engelbert Mühlbacher, ed., MGH DD Kar. I (Hannover: Hahn, 1906), 9. See also Lebecq, "Role of Monasteries," 142.

5 Grierson and Blackburn, Medieval Coinage, 124, 135.

6 Ljungkvist, "Continental Imports," 34-36; Näsman, "Justinianic Era," 268.

7 Martin Segschneider, "Trade and Centrality between the Rhine and the Limfjord around $500 \mathrm{AD}$ : The Beachmarket on the Northfrisian Island Amrum and its Context," in Central Places in the Migration and the Merovingian Periods, ed. Birgitta Hårdh and Lars Larsson (Stockholm: Almqvist \& Wiksell, 2002), 248, 253; Ljungkvist, "Continental Imports," 31-39. 
8 Ibid., 42-43; Wilhelm Holmqvist and Birgit Arrhenius, eds., Excavations at Helgö I: Report for 1954-1956 (Stockholm: Almqvist \& Wiksell, 1961), 123.

9 Loveluck, Northwest Europe, 195;Van Es, “Dorestad Centred," 162.

10 Grierson and Blackburn, Medieval Coinage, 151.

11 Ursula Koch, "Nordeuropäisches Fundmaterial in Gräbern Süddeutschlands rechts des Rheins," in Völker an Nord- und Ostsee und die Franken, ed. Uta von Freeden, Ursula Koch, and Alfried Wieczorek (Bonn: Habelt, 1999), 175-194; Charlotte Behr, "Using Bracteates as Evidence for Long-Distance Contacts," in Incipient Globalisation? Long-Distance Contacts in the Sixth Century, ed. Anthea Harris (Oxford: BAR, 2007), 16.

12 Wim Dijkman, "Artisanal Activities in Merovingian Maastricht," Medieval and Modern Matters 4 (2013): 26-28; Frank Siegmund, "Merovingian Beads on the Lower Rhine," Beads 7 (1995): 43.

13 Sindbæk, "Emergence of Towns,"121-125; Ulf Näsman, "Exchange and Politics: The Eighth-Early Ninth Century in Denmark," in The Long Eighth Century: Production, Distribution and Demand, ed. Inge Lyse Hansen and Chris Wickham (Leiden: Brill, 2000), 47.

14 Lars Pilø, "The Pottery," in Things from the Town: Artefacts and Inhabitants in VikingAge Kaupang, ed. Dagfinn Skre (Aarhus: Aarhus University Press, 2011), 281.

15 The latter type of pottery is also referred to as Muschelgrus-ware. Ibid., 295-296, 289-290; Helena Hamerow, Early Medieval Settlements: The Archaeology of Rural Communities in Northwest Europe, 400-900 (Oxford: Oxford University Press, 2002), 172; Mats Roslund, Guests in the House: Cultural Transmission between Slavs and Scandinavians 900 to 1300 AD (Leiden: Brill, 2007), 402; Walter Janssen, Die Importkeramik von Haithabu (Neumünster: Karl Wachholtz, 1987), 44, 71.

16 Claus Feveile, Viking Ribe: Trade, Power and Faith (Ribe: Sydvestjyske Museer, 2013), 21, 51;Verhulst, Carolingian Economy, 109.

17 Sindbæk, "Emergence of Towns," 123-124, 126.

18 Pilø, "Pottery," 294-295.

19 Näsman, "Exchange and Politics," 40-41.

20 Johan Callmer and Julian Henderson, "Glassworking at Åhus, S. Sweden (Eighth Century AD)," Laborativ arkeologi 5 (1991): 153.

21 The latter site is thought to correspond to eighth-century Reric (see also Section II.2.1). Sindbæk, "Emergence of Towns," 122-125; Björn Ambrosiani, "Birka and Dorestad," in In Discussion with the Past, ed. H. Sarfatij and W.J.H. Verwers (Zwolle: SPA, 1999), 241.

22 Johan Callmer, "Archaeological Sources for the Presence of Frisian Agents of Trade in Northern Europe ca. AD 700-900," in Studien zur Archäologie des Ostseeraumes: von der Eisenzeit zum Mittelalter, ed. A. Wesse (Neumünster: Wachholtz, 1998), 473; Bergljot Solberg, "Weapon Export from the Continent to the Nordic Countries in the Carolingian Period," Studien zur Sachsenforschung 7 (1991): 244, 250.

23 Lebecq, Marchands, 1983, I:131-134.

24 Näsman, “Justinianic Era," 277.

25 Björn Ambrosiani, "Regalia and Symbols in the Boat-Graves," in Vendel Period Studies: Transactions of the Boat-Grave Symposium in Stockholm, Feb 2-3, 1981, ed. Jan Peder Lamm and H. Nordström (Stockholm: Museum of National Antiquities, 1983), 27-28; Birgit Arrhenius, "The Chronology of the Vendel Graves," in Vendel Period Studies, 64-65. 
26 Signe Horn Fuglesang, "Copying and Creativity in Early Viking Ornament," in Early Medieval Art and Archaeology in the Northern World, ed. Andrew Reynolds and Leslie Webster (Leiden: Brill, 2013), 829-830.

27 Maria Baastrup, "Continental and Insular Imports in Viking Age Denmark: On Transcultural Competences, Actor Networks and High-Cultural Differentiation," in Northern Worlds: Landscapes, Interactions and Dynamics, ed. Hans Christian Gulløv (Copenhagen: National Museum of Denmark, 2014), 358; Gabor Thomas, "Carolingian Culture in the North Sea World: Rethinking the Cultural Dynamics of Personal Adornment in Viking-Age England," European Journal of Archaeology 15, no. 3 (2012): 497, 507.

28 Van Es and Verwers, Excavations at Dorestad IV, 318.

29 Steven Ashby, Ashley Coutu, and Søren Sindbæk, "Urban Networks and Arctic Outlands: Craft Specialists and Reindeer Antler in Viking Towns," European Journal of Archaeology 18, no. 4 (2015): 693-696.

30 Hubert Berke, "Haustiere, Handwerker und Händler: Vorläufige archäozoologische Ergebnisse der Ausgrabungen am Heumarkt in Köln," Kölner Jahrbuch 30 (1997): 411.

31 Willemsen, "Scattered across the Waterside," 70, 75.

32 Verhulst, Carolingian Economy, 108.

33 Näsman, "Ethnogenesis," 5; Kirsten Bendixen, "Sceattas and Other Coin Finds," in Ribe Excavations 1970-76, ed. Mogens Bencard, vol. 1 (Esbjerg: Sydjysk Universitersforlag, 1981), 93-95.

34 P. le Gentilhomme, "The Circulation of Sceats in Merovingian Gaul," British Numismatic Journal 24 (1944): 209.

35 Hodges, "North Sea Trade," 199; Ashby, "What Really Caused the Viking Age?," 91.

36 Peter Sawyer, "The Viking Expansion," in The Cambridge History of Scandinavia, ed. Knut Helle, vol. I (Cambridge: Cambridge University Press, 2003), 107108; Angus Somerville and R. Andrew McDonald, The Vikings and Their Age (Toronto: University of Toronto Press, 2013), 9.

37 Lebecq, Marchands, 1983, I:237-238; Johan Callmer, "Scandinavia and the Continent in the Viking Age," in The Viking World, ed. Stefan Brink and Neil Price (London: Routledge, 2008), 441.

38 Aliquando nempe quidam ex nobis Dorstadum adeuntes [...]. Rimbert, VA, 58. For Ohthere's account, see Bately, The Old English Orosius, 13-16.

$39[\ldots]$ on his dagum cuomon arest .iii. scipu, 7 pa se gerefa parto rad 7 hie wolde drifan to pas cyninges tune py he nyste hwat hi waron, 7 hiene mon ofslog. Dat waron pa arestan scipu deniscra monna pe Angelcynnes lond gesohton. Janet Bately, ed., The Anglo-Saxon Chronicle: A Collaborative Edition - MS A (Cambridge: Brewer, 1986), 39; Sunhild Kleingärtner and Gareth Williams, "Contacts \& Exchange," in Vikings: Life and Legend, ed. Gareth Williams, Peter Pentz, and Matthias Wemhoff (London: British Museum Press, 2014), 50.

40 This early process of cognitive mapping has also recently been discussed by HeenPettersen, "Viking Activity," 533-536.

$41[\ldots]$ quibusdam Normannis, qui iter et portus maris ac fluminum mare influentium notos habebant [...]. Flodoard, "HRE," 472.

42 Bately, The Old English Orosius, 13-16. See also Costambeys, Innes, and MacLean, Carolingian World, 330.

43 Et cum negotiatores, qui cum eis ibant, se viriliter defenderint, et primo quidem victoriam coeperint, in secondo tamen ab eisdem pyratis devicti ac superati sunt [...]. Rimbert, VA, 31-32. Translation from Robinson, Anskar, 47. 
44 Alcuin, "VW," 123.

45 Interea Godofridus rex Danorum per negotiatores a quosdam mandavit [...]. Kurze, $A R F$, 128. Translation from Scholz, Carolingian Chronicles, 90.

46 Daniel Melleno, "North Sea Networks: Trade and Communication from the Seventh to the Tenth Century," Comitatus 45 (2014): 81.

$47[\ldots]$ propter hiemis asperitatem, quae interpartes commeandi viam claudebat [...]. Kurze, ARF, 134. Translation from Scholz, Carolingian Chronicles, 93.

48 Poeta Saxo, “Annalium," 51. See also Section V.1.3.

49 Barrett, "What Caused the Viking Age?," 680-681.

1 [...] hapenra manna [...].G.P. Cubbin, ed., The Anglo-Saxon Chronicle: A Collaborative Edition - MS D (Cambridge: Brewer, 1996), 17. Analogous accounts also feature in MSS E and F. See Susan Irvine, ed., The Anglo-Saxon Chronicle: A Collaborative Edition - MS E (Cambridge: Brewer, 2004), 42; Peter S. Baker, ed., The Anglo-Saxon Chronicle: A Collaborative Edition - MS F (Cambridge: Brewer, 2000), 55.

$2[\ldots]$ calcaverunt corpora sanctorum in templo Dei quasi sterquilinium in platea. Alcuin, "Epistolae," in MGH Epp. IV, ed. Ernst Dümmler (Berlin: Weidmann, 1895), 57.

3 Downham, "Earliest Viking Activity," 5-6, 11-12; Jesch, The Viking Diaspora, 8.

4 Egressique ad terras, pagum unum de regno Theudorici devastant atque captivant [...]. Gregory of Tours, "Historiarum libri X," 99.

5 The event is reinterpreted by the early eighth-century Liber historiae Francorum, whilst Frisian and Anglo-Saxon oral traditions are thought to survive in the Liber monstrorum and epic poem Beowulf, respectively. Frederick Biggs, "History and Fiction in the Frisian Raid," in The Dating of Beowulf: A Reassessment (Woodbridge: Boydell \& Brewer, 2014), 140-142.

$6[\ldots]$ quae tibi sit virtus cum prosperitate superna / Saxonis et Dani gens cito victa probat / Bordaa quo fluvius sinuoso gurgite currit / hic adversa acies te duce caesa ruit. Venantius Fortunatus, Carminum epistularum expositionum, ed. Friedrich Leo, MGH AA IV-I (Berlin: Weidmann, 1881), 160.

7 John Haywood, Dark Age Naval Power: A Reassessment of Frankish and Anglo-Saxon Seafaring Activity (London: Routledge, 1991), 119.

8 [...] vel ex insidiis ferocissimorum terrae illius habitatorum [...] Alcuin, "VW," 124. Translation from Noble and Head, "The Life of Saint Willibrord," 199.

9 Paganae vero naves [...] multa mala fecerunt per insulas oceani partibus Aquitaniae. Pars tamen ex illis periit; et occisi sunt in litore quasi centum quinque viri ex illis praedatoribus. Alcuin, "Epistolae," 309. Translation from Alcuin of York: His Life and Letters, trans. Stephen Allott (York: Ebor Press, 1974), 79.

10 See, for example, Sawyer, "Viking Expansion," 105; Benjamin Hudson, "Prologue: The Medieval Atlantic Ocean," in Studies in the Medieval Atlantic, ed. Benjamin Hudson (New York: Palgrave Macmillan, 2012), 10.

11 Yaniv Fox, Power and Religion in Merovingian Gaul: Columbanian Monasticism and the Frankish Elites (Cambridge: Cambridge University Press, 2014), 118-119; Jean Renaud, Les Îles de Vendée face aux Vikings (Verrières: l'Etrave, 2008), 7; Bernhard von Simson, ed., Annales Mettenses priores, MGH SR G X (Hannover: Hahn, 1905), 36.

12 Élisabeth Ridel, "From Scotland to Normandy: The Celtic Sea Route of the Vikings," in West over Sea: Studies in Scandinavian Sea-Borne Expansion and Settlement before 1300, ed. Beverly Ballin Smith, Simon Taylor, and Gareth Williams (Leiden: Brill, 2007), 86.

$13[\ldots]$ navis Sarracenorum $[\ldots]$ ad Oiam $[$ Yeu $]$ venerit insulam; $[\ldots]$ voluit devenire ad nostre insulae portum [...]. Ermentar, "De translationibus et miraculis sancti Filiberti," in 
Monuments de l'histoire des abbayes de Saint-Philibert, ed. René Poupardin (Paris: Picard, 1905), 66. Stephen M. Lewis, citing Walther Vogel, has stated that contemporary chroniclers never referred to Saracens as 'pagans', although examples to the contrary seem to be in evidence. Lewis, "Salt and the Earliest Scandinavian Raids," 106; Vogel, Die Normannen und das fränkische Reich, 51. Examples are mentioned in John Tolan, Saracens: Islam in the Medieval European Imagination (New York: Columbia University Press, 2002), 77; Michael McCormick, Eternal Victory: Triumphal Rulership in Late Antiquity, Byzantium, and the Early Medieval West (Cambridge: Cambridge University Press, 1986), 348.

$14[\ldots]$ litus oceani Gallici perlustravit, in ipso mari, quod tunc piratis infestum erat [...]. Kurze, $A R F, 110$.

15 [...] contra Nordmannos, qui Dani vocantur, primo pyraticam exercentes [...]. Nordmanni Gallicum litus atque Germanicum assidua infestatione vastabant [...]. Einhard, VKM, 17, 21. Translation from Noble, "Life of Charles," 33, 36.

16 [...] Oceani litus [...] Infestum quod Northmanni fecere pyrate [...]. Poeta Saxo, "Annalium," 44. Translation from Mary McKinney, trans., The Saxon Poet's Life of Charles the Great (New York: Pageant Press, 1956), 65.

$17[\ldots]$ legati $[\ldots]$ reversi sunt, unus ex eis, Aldulfus diaconus, a piratis captus est, ceteris sine periculo traicientibus, ductusque ab eis in Brittaniam a quodam Coenulfi regis homine redemptus est Romamque reversus. Kurze, ARF, 128. Translation from Scholz, Carolingian Chronicles, 89-90. These proceedings are likewise briefly alluded to in a contemporary letter sent to Charlemagne by Pope Leo III. See Karl Hampe, ed., "Leonis III. papae epistolae X," in MGH Epp.V (Berlin: Weidmann, 1899), 93.

18 Sawyer, Kings and Vikings, 78.

19 [...] classem ducentarum navium de Nordmannia [...]. Kurze, ARF, 131. Translation from Scholz, Carolingian Chronicles, 91. See also Section II.1.2.

20 Exierunt autem Normanni cum navibus suis in Frisia, et fecerunt ibi grande malum, ceperunt viros, mulieres et praedam magnam. Pertz, "CM," 311. Although most of the CM text is based on familiar source material, parts of its coverage between 803 and 818 including the 813 incursion in Frisia - have no known antecedent, and are thought to draw on a now-lost continuation of the contemporary Annales Laureshamenses. See David Claszen and J.M.J.G. Kats, "Chronicon Moissiacense maius: A Carolingian World Chronicle” (MPhil Diss., Leiden University, 2012), vol. I, 122-123.

$21[. .$.$] tredecim piraticae naves [...]. Tandem in Aquitanico litore prosperis usae successibus$ vico quodam, qui vocatur Buyn, ad integrum depopulato [...]. Kurze, ARF, 153-154. Translation from Scholz, Carolingian Chronicles, 108. Charlemagne's supposed sighting of viking ships off the coast of Narbonne, described by Notker, is thought to have been wholly invented. See Noble, "The Deeds of Emperor Charles the Great," 108.

$22[\ldots]$ propter incursiones barbarorum qui frequenter ipsum monasterium depopulantur [...]. Martin Bouquet, ed., "Diplomata Ludovici Pii imperatoris," in Recueil des historiens des Gaules et de la France, vol.VI (Paris: Libraires associés, 1749), 516-517.

23 Ermentar, “MSF," 23.

$24[\ldots]$ piratarum incursionibus creberrime coepisset infestari $[\ldots]$. Bouquet, "Diplomata Ludovici," 564.

25 [...] classis de Danis [...] ad emporium quod vocatur Dorestad venientes, omnia diripuerunt. Waitz, $A B$, 9. For $A X$ reference, see Georg Heinrich Pertz, ed., "Annales Xantenses," in MGH SS II (Hannover: Hahn, 1829), 226.

26 Waitz, $A B$, 9-13; Pertz, "AX," 226; Kurze, $A F, 27-28$. 
27 Wickham, Early Middle Ages, 682.

28 Costambeys, Innes, and MacLean, Carolingian World, 347.

29 Christian Cooijmans, "The Controlled Decline of Viking-Ruled Dorestad," Northern Studies 47 (2015): 35.

30 [...] quemadmodum in partibus Britanniae de cuiusdam sancti viri cineribus noscuntur egisse [...]. Ermentar, "MSF"' 24. The specifics of this particular attack are unknown.

31 Ibid., 59.

32 Kurze, $A F, 27-28$;Waitz, $A B, 13,22$; Pertz, “AX," 226.

$33[\ldots]$ non parum incommodi nostris finibus intulerunt. Waitz, $A B$, 22. The $A B$ also mention the loss of a viking fleet due to a storm in 838, presumably off the Frankish coast. Ibid., 15.

34 [...] inde per Vetus-Treiectum [...]. Ibid., 9.

35 Kaj van Vliet, "Traiecti Muros Heu: The Bishop of Utrecht during and after the Viking Invasions of Frisia (834-925)," in Vikings on the Rhine: Recent Research on Early Medieval Relations between the Rhinelands and Scandinavia, ed. Rudolf Simek and Ulrike Engel (Vienna: Fassbaender, 2004), 134.

36 A conservative estimate based on the average speed (under oar, in disadvantageous conditions) of Skuldelev 5, considered to be analogous to the vessels used by early vikings on the European rivers. See R. Johansen, "The Viking Ships of Skuldelev," in Sailing into the Past: Learning from Replica Ships, ed. Jenny Bennett (Barnsley: Seaforth, 2009), 62-67.

37 The riverine distance between the North Sea and Dorestad would have been c. ninety-five $\mathrm{km}$ along the Rhine, and c. one hundred $\mathrm{km}$ along the Lek.

38 Although some scholars have assumed that the episcopal centre of Utrecht would have also been sacked during the expedition of 834, no convincing evidence for such an early incursion has been put forward. See, for example, Päffgen, "Urban Settlements," 83; Torsten Capelle, "Die Wikinger auf dem westeuropäischen Kontinent," Deutsches Schiffahrtsarchiv 29 (2006): 25.

39 Waitz, $A B, 13$; Kurze, $A F, 28$; Pertz, “AX," 226. The centre in question is commonly equated with the villa Walichrum identified by Alcuin in his $V W$. See Alcuin, "VW," 128; Stéphane Lebecq, "L'emporium proto-médiéval de Walcheren-Domburg: une mise en perspective," in Peasants and Townsmen in Medieval Europe, ed. Jean-Marie Duvosquel and Erik Thoen (Ghent: Snoeck-Ducaju, 1995), 80.

40 [...] Witlam emporium iuxta ostium Mosae fluminis [...]. Kurze, AF, 27.

41 Melleno, "North Sea Networks," 84.

42 Coupland, "Vikings in Francia and Anglo-Saxon England," 192.

$43[\ldots]$ ceperunt $[\ldots]$ praedam magnam. Pertz, "CM," 311. [...] cum ingenti praeda [...] reversae sunt. Kurze, $A R F, 154$.

$44[\ldots]$ suorum damna perpeti [...]. Ermentar, "MSF," 24. Translation from David Herlihy, ed., The History of Feudalism (London: Macmillan, 1970), 9.

$45[\ldots]$ centum libras argenti a Frisonibus iam esse solutas $[\ldots]$. Kurze, $A R F, 131$. Translation from Scholz, Carolingian Chronicles, 92.

$46[\ldots]$ a Frisonibus tributum acceperunt $[\ldots]$. Kurze, $A F, 27 .[\ldots]$ censu prout libuit exacto [...] tributa similiter exegerunt. Waitz, AB, 13. Latter translation from Nelson, Annals of St. Bertin, 37.

47 Peter Kurrild-Klitgaard and Gert Svendsen, "Rational Bandits: Plunder, Public Goods, and the Vikings," Public Choice 117 (2003): 236.

48 Pertz, "CM," 311; Waitz, $A B, 9$. 
$49[\ldots]$ pagani $[. .$.$] multasque feminas inde abduxerunt captivas, cum infinita diversi generis$ pecunia. Pertz, “AX,” 226.

50 Particular comparison is warranted to the large number of women seized during the 821 attack on Étar (Howth, Ireland), which has likewise been speculated to signify the existence of an unfamiliar local nunnery. See Dáibhí Ó Cróinín, Early Medieval Ireland 400-1200 (London: Longman, 1995), 236. For the annalistic entry, see Seán Mac Airt and Gearóid Mac Niocaill, trans., The Annals of Ulster (Dublin: Institute for Advanced Studies, 1983), 276-277.

51 [...] aliqui comprehensi sunt et postea redempti. Thegan, "Vita Hludowici imperatoris," in MGH SS II, ed. Georg Heinrich Pertz (Hannover: Hahn, 1829), 604.

52 See, for example, Peter Sawyer, "The Viking Legacy," in The Oxford Illustrated History of the Vikings, ed. Peter Sawyer (Oxford: Oxford University Press, 1997), 252; Mary Valante, "Castrating Monks: Vikings, Slave Trade, and the Value of Eunuchs," in Castration and Culture in the Middle Ages, ed. Larissa Tracy (Woodbridge: Boydell \& Brewer, 2013), 175-177.

53 [...] Northmannorum dux Alfdeni dictus / Augusto magna sese comitante caterva / Subdidit atque fidem studuit firmare perennem. Poeta Saxo, "Annalium," 51.

54 [...] Hemmingum Halpdani filium [...]. Kurze, AF, 28. [...] ibi cecidit Hemminch qui erat ex stirpe Danorum, dux christianissimus [...]. Thegan, "Vita Hludowici," 604. See Coupland, "Poachers to Gamekeepers," 87-88.

55 The land grant is mentioned by a number of contemporary authors, including the $A R F$ annalist, Thegan, and the Astronomer. See Kurze, $A R F, 170$; Thegan, "Vita Hludowici," 597; Astronomus, "Vita Hludowici imperatoris," in MGH SRG LXIV, ed. Ernst Tremp (Hannover: Hahn, 1995), 432.

56 Herlihy, The History of Feudalism, 75.

57 Sawyer, "Viking Expansion," 106. See also Section VI.4.2.1.

58 See, for example, Coupland, "Vikings in Francia and Anglo-Saxon England," 193; Andreas Mohr, Das Wissen über die Anderen: zur Darstellung fremder Völker in den fränkischen Quellen der Karolingerzeit (Münster: Waxmann, 2005), 191. See also Irene Baug et al., "The Beginning of the Viking Age in the West," Journal of Maritime Archaeology 14 (2019): 71.

59 Beverley Ballin Smith, "Norwick: Shetland's First Viking Settlement?," in West over Sea: Studies in Scandinavian Sea-Borne Expansion and Settlement before 1300, ed. Beverly Ballin Smith, Simon Taylor, and Gareth Williams (Leiden: Brill, 2007), 294.

60 See, for example, Barbara Crawford, Scandinavian Scotland (Leicester: Leicester University Press, 1987), 40; James Graham-Campbell and Colleen Batey, Vikings in Scotland: An Archaeological Survey (Edinburgh: Edinburgh University Press, 1998), 24.

61 Olwyn Owen, "The Scar Boat Burial - and the Missing Decades of the EarlyViking Age in Orkney and Shetland," in Scandinavia and Europe 800-1350: Contact, Conflict, and Coexistence, ed. Jonathan Adams and Katherine Holman (Turnhout: Brepols, 2004), 29.

62 Loveluck, Northwest Europe, 183; Jankuhn, “Trade and Settlement," 41.

63 Based on an average seafaring velocity of six knots for Skuldelev 5 (under sail, with wind astern), and approximate distances of one thousand seven hundred fifty $\mathrm{km}$ for Ribe-Noirmoutier and nine hundred twenty-five $\mathrm{km}$ for DublinNoirmoutier (using coastal routes, wherever possible). See Johansen, "Viking Ships of Skuldelev," 66.

$64[\ldots]$ parvus pecoris numerus abactus est. Kurze, ARF, 153. Translation from Scholz, Carolingian Chronicles, 108. 
65 Having subsequently reached Bouin, these vikings are noted to have returned ad propria - commonly 'homeward' but lit. 'to their own [places]'- a phrasing open to interpretation and by no means precluding coastal or insular encampments. See Kurze, $A R F, 154$.

66 Kurze, $A F, 28$; Thegan, "Vita Hludowici," 604. See also note 54.

67 Willemsen, "Scattered across the Waterside," 70.

68 [...] litus oceani Gallici perlustravit, in ipso mari, quod tunc piratis infestum erat, classem instituit, praesidia disposuit [...]. Kurze, ARF, 110. These earlier countermeasures are likewise referenced in capitularies from 802 and 808. See Alfred Boretius, ed., "Capitularia missorum specialia," in MGH Capit. I (Hannover: Hahn, 1883), 100; Boretius, ed., "Capitula cum primis conferenda," in MGH Capit. I (Hannover: Hahn, 1883), 139.

69 Kurze, ARF, 135.

70 Molitus est et classem contra bellum Nordmannicum, aedificatis ad hoc navibus iuxta flumina, quae et de Gallia et de Germania septentrionalem in fluunt oceanum. [...] per omnes portus et ostia fluminum, qua naves recipe posse videbantur, stationibus et excubiis dispositis, ne qua hostis exire potuisset, tali munitione prohibuit. Einhard, VKM, 21. Translation from Noble, "Life of Charles," 36-37.

71 Quam curam etiam filio iniunxit super Hrodanum et Garonnam et Silidam. Astronomus, "Vita Hludowici," 324.Translation from Thomas Noble, trans., "The Life of Emperor Louis," in Charlemagne and Louis the Pious (University Park, PA: Pennsylvania State University Press, 2009), 239.

72 Astronomus, "Vita Hludowici," 325n181.

73 [...] comites qui ad custodiam maritimam deputati sunt [...]. Alfred Boretius, ed., "Capitula missorum Hludovici," in MGH Capit. I (Hannover: Hahn, 1883), 301. See also Pertz,"CM," 311.

74 Iactabat etiam se brevi Aquasgrani ubi regis comitatus erat, cum maximis copiis adventurum. Einhard, $V K M, 17$. Translation from Noble, "Life of Charles," 33.

75 Kurze, $A R F, 154$.

$76[\ldots]$ interfecta est de paganis non minima multitude. Pertz, "AX," 226.

77 Thegan, "Vita Hludowici," 604; Waitz, AB, 14-15; Kurze, $A F, 28$.

78 Ermentar, "MSF," 25; Bouquet, "Diplomata Ludovici," 564.

79 Although no direct mention is made of a Carolingian army, the emperor's intent to 'crush their insolence' (Ad quorum conprimendam [...] insolentiam) reveals a planned military response. Astronomus, "Vita Hludowici," 510. Translation from Noble, "The Life of Emperor Louis," 290. See also Waitz, $A B, 13$.

80 Kurze, ARF, 153-154; Pertz, “AX," 226; Pertz, ed., "Annales Engolismenses,” in MGH SS XVI (Hannover: Hahn, 1859), 485.

81 Alfred Boretius, ed., "Capitulare Haristallense," in MGH Capit. I (Hannover: Hahn, 1883), 51; Boretius, ed., "Capitulare Mantuanum," in MGH Capit. I, 190; Boretius, ed., "Capitulare Missorum in Theodonis villa datum secundum," in MGH Capit. I, 123; Boretius, ed., "Capitulare Bononiense," in MGH Capit. I, 167. Another Capitulare missorum, issued in 803 , likewise prohibits the sale of bangae (arm guards) and bruniae (mail tunics) to merchants, but makes no mention of foreign exports. Boretius, ed., "Capitulare missorum," in MGH Capit. I, 115. A variant manuscript, held by the Vatican, does, however, allude to merchants foras marcas (i.e. from bordering regions). See Signe Horn Fuglesang, "Skriftlige kilder for karolingisk våpeneksport til Skandinavia?," Collegium Medievale 13 (2000): 179-180.

82 Ljungkvist, "Continental Imports," 42-43. See also Section IV.1. 
83 Anne Stalsberg, "Herstellung und Verbreitung der Vlfberht-Schwertklingen. Eine Neubewertung," Zeitschrift für Archäologie des Mittelalters 36 (2008): 92-95, 111.

84 Ut nullus [...] amissario foris regno nostro vendat [...]. Boretius, "Capitulare Mantuanum," 190.

85 Kurze, $A R F, 131$; Kurze, $A F, 27-28$.

$1[\ldots]$ angescit numerus navium, crescit innumerabilis multitudo Nortmannorum; fiunt passim Christianorum strages, depredationes, vastationes, incensiones, sicuti quandiu seculum stabit manifestis patebit indiciis. Ermentar, "MSF," 60.

$2[\ldots]$ copiosus exercitus Normannorum, superbo tumentique corde, cum valido navium apparatu, christianorum fines contingerent atque intrarent: quod retroactis temporibus [...] nequaquam factum audivimus sed neque relegimus. "Translatio sancti Germani Parisiensis," Analecta Bollandiana 2 (1883): 71.

3 [...] omnia monasteria seu [quae]cumque loca flumini Sequanae adhaerentia [...] depopulati sunt [...]. Waitz, AB, 25. Translation from Nelson, Annals of St. Bertin, 50.

4 Waitz, $A B$, 25; Georg Heinrich Pertz, ed., "Fragmentum chronici Fontanellensis," in MGH SS II (Hannover: Hahn, 1829), 301. The population number is found in Paul Bairoch, Jean Batou, and Pierre Chèvre, La population des villes européennes: banque de données et analyse sommaire des résultats, 800-1850 (Geneva: Droz, 1988), 29. See also Loveluck, Northwest Europe, 174.

5 [...] undique vallant, et sine mora [...] capiunt, vastant, diripiunt. From the Angers Miscellany, MS 817, Municipal Library, Angers, fol. 135v. This passage is thought to represent a contemporary account of the attack. See Simon Coupland, "The Vikings on the Continent in Myth and History," History 88, no. 290 (2003): 191. The number of ships involved is provided by Ermentar, "MSF," 59.

6 See, for example, Waitz, AB, 32; Pertz, "AEng," 486.

7 Nordomannorum naves centum viginti mense Martio per Sequanam hinc et abinde cuncta vastantes, Loticiam Parisiorum, nullo penitus obsistente, pervadunt. Waitz, AB, 32. Translation from Nelson, Annals of St. Bertin, 60.

8 [...] Normannorum populi [...] cursu praepropero sabbato sancto paschalis solemnitatis Parisius venerunt, et ipsa quidem nocte siluerunt. Mane autem factum [...] e navibus cum magno impetu proruperunt [...] ceperunt [...]. "TSG," 80.

9 Williams, "Raiding and Warfare," 195; Carroll Gillmor, "War on the Rivers: Viking Numbers and Mobility on the Seine and Loire, 841-886," Viator 19 (1988): 79.

10 Please refer to Section I.3 for a further discussion on the perceived biases of contemporary textual sources.

11 [...] sed cesi sunt ex eis a Fresionibus plus quam 12000. Pertz, “AX," 228.

12 Nemo tamen mortalium enumerare potest [...] quot milia hominum in diversis proeliis [...] ex utraque parte. Georg Heinrich Pertz, ed., "Annales Vedastini," in MGH SS II (Hannover: Hahn, 1829), 202. [...] M que truces posthac chile - seranta chile id extat $[\ldots]$. Abbo, $B P U, 5,34$.

13 Erant $[. .$.$] XXX et eo amplius adversariorum milia [\ldots]$. Kurze, $R P, 125 .[\ldots]$ unaque die ex eis ad centum milia caederentur. Widukind, Gestarum Saxonicarum, 41. Large figures like these - in multiples of a thousand - may have been deliberate numerical references to eschatological events in scripture, evoking, for example, the size of the mounted army following four released angels from the Euphrates to torment mankind, ‘20,000 times 10,000' strong (vicies milies dena milia). Rev. 9:1316 (Vulg.).

14 Unusually specific statistics like the 252 ships in Frisia (852) are difficult to substantiate, but may have been deliberately chosen to lend credibility to an otherwise 
exaggerated claim. Waitz, $A B, 41$. See Section VI.1.1.1 for a more wide-ranging consideration of fleet logistics.

15 Peter Sawyer, The Age of the Vikings, 2nd ed. (London: Edward Arnold, 1971), 128-131; Albert d'Haenens, Les invasions normandes en Belgique au IX siècle (Louvain: Publications Universitaires de Louvain, 1967), 69-72.

16 N.P. Brooks, "England in the Ninth Century: The Crucible of Defeat," Transactions of the Royal Historical Society 29 (1979): 6.

17 The reduction in incursions for the 860s and 870s has been linked to concurrent large-scale viking activity in Anglo-Saxon England. See discussion in Section VI.1.2.3.

18 Timothy Reuter, "Introduction: Reading the Tenth Century," in The New Cambridge Medieval History, ed. Timothy Reuter, vol. III (Cambridge: Cambridge University Press, 2000), 2-6.

$19[\ldots]$ adsumptis Nordmannorum exercitibus, cum multitudine navium Fresiam [...] devastat. [...] Ceterorum vero pars Menapios, Tarvisios aliosque maritimos depraedantur, pars Brittaniam insulam Anglosque impetentes [...]. Waitz, AB, 38.

20 Pyratae Danorum [...] Rodanum ingrediuntur [...]. Dani noviter advenientes monasterium Sancti Walarici

et Samarobricam Ambianorum civitatem [...] vastant. Alii quoque eorum insulam Reni Patavum simili furore invadunt. Hi vero qui in Sequana morantur Noviomum civitatem noctu adgressi [...] Ibid., 51-52.

21 Pertz, “AX,” 228; Waitz, AB, 33; Pertz, “AEng,” 486.

22 Berno dux partis pyratarum Sequanae insistentium [...] Waitz, AB, 49. [...] indeque ad obsidentes castellum perveniunt et eorum societate iunguntur. Ibid., 56 .

23 Ibid., 57-58.

$24[\ldots]$ circumcedit castrum aliorum paganorum [...]. Text and translation from Caroline Brett, ed., "Gesta sanctorum Rotonensium," in The Monks of Redon (Woodbridge: Boydell, 1989), 214-215.

25 Only a single recorded viking incursion into Carolingian territory, targeting Hamburg in 845 , seems to have been instigated by a Scandinavian monarch (Horik) during this period. See Waitz, $A B, 32$; Kurze, $A F, 35$.

26 [...] classis Danorum [...], ducibus Rorico et Godefrido. [...] classis Sydroc et Godefridi ducum Danorum [...]. Pertz, "AFont," 303-304. Both references are thought to refer to the same Godfrid.

27 Waitz, $A B, 119,121,153$. The $A F$ also mention a princeps called 'Hals' in their company, who is otherwise unattested. Kurze, $A F, 108$.

28 See also Price, "Pirates of the North Sea?," 163.

29 [...] iunctis viribus [...] plurimam stragem ac depopulationem fecerunt. Pertz, "AFont," 304. Interea Sigifrid cum magna multitudine Nordmannorum caeteris, qui ibi residebant. auxilium laturus venit $[. .$.$] . Kurze, A F, 105$. Latter translation from Reuter, Annals of Fulda, 101.

30 Interea Ragenoldus [...] Franciam [...] coniunctis sibi plurimis ex Rodomo, depraedatur. Flodoard, "Annales," in MGH SS III, ed. Georg Heinrich Pertz (Hannover: Hahn, 1839), 372. Translation from Steven Fanning and Bernard S. Bachrach, trans., The Annals of Flodoard of Reims (Peterborough, ON: Broadview Press, 2004), 8-9.

31 Waitz, AB, 57; Pertz, “AV," 201.

32 See, for example, McKitterick, Frankish Kingdoms, 236; Sawyer, "Viking Expansion," 113. For the same reason, the author is reluctant to subscribe to the hypothesis that these regions would have each hosted an entrenched, large-scale viking army over 
protracted periods of time, analogous to the so-called Great Army in Anglo-Saxon England. See Price, "Pirates of the North Sea?," 170.

33 Waitz, $A B, 56$. See also Section II.1.3, esp. note 99.

$34[\ldots]$ Danorum electi, de his qui in Fossatis resederant [...]. Waitz, AB, 57. Translation from Nelson, Annals of St. Bertin, 98. Ceteri [...] redierunt ad suos. Pertz, “AX,” 231.

35 [...] subito apparuerunt speculatores Nortmannorum. Kurze, RP, 137. Translation from Simon MacLean, trans., History and Politics in Late Carolingian and Ottonian Europe: The Chronicle of Regino of Prüm and Adalbert of Magdeburg (Manchester: Manchester University Press, 2009), 210.

36 See also Price, "Ship-Men," 57.

37 Paris would have had an estimated population of twenty-five thousand at this time. Bairoch, Batou, and Chèvre, Population des villes européennes, 28. Abbo states that no more than two hundred people were present to defend the civitas. Abbo, $B P U, 34-35$.

38 The unwieldy nature of larger viking fleets seems to have tipped off the people of Paris (845), Tours (853), and Angers (873) to incoming attacks, for example. See also Section VI.3.2.1.

39 Gillmor, "War on the Rivers," 81-82.

$40[\ldots]$ navibus magnis, quas nostrates bargas vocant [...]. Waitz, $A B, 132$. Translation from Nelson, Annals of St. Bertin, 196.

41 Septies aerias centum praeter iuniores [...] naves [...]. Text and translation from Abbo, BPU, 28-29.

42 Neil Price, The Vikings in Brittany (London: Viking Society for Northern Research, 1989), 64-72.

43 Gillmor, "War on the Rivers," 82.

44 Pentz, "Ships \& the Vikings," 208-209.

45 Hildegar, "Vita Faronis episcopi Meldensis," in MGH SRM V, ed. Bruno Krusch and W. Levison (Hannover: Hahn, 1910), 201.

46 [...] a Normannis [...] navibus occupatis [...]. Waitz, AB, 57.Translation from Nelson, Annals of St. Bertin, 98. The type and number of confiscated vessels is unclear, and both military and civilian craft (i.e. ferries) may be implied.

47 Gillmor, "War on the Rivers," 83.

$48[\ldots]$ convectis a continenti domibus $[\ldots]$. Waitz, AB, 29. [...] suis suorumque copiis tutissimum receptaculum $[\ldots]$ cum mulieribus et parvulis $[\ldots]$ intrant $[\ldots]$. Kurze, $R P, 106$.

49 E.g. Pertz, “AV,” 199; Kurze, AF, 103; Bately, ASC (A), 55.

50 [...] pedestri cum eis proelio congressos [...]. Lupus Servatus, "Epistolae," in MGH Epp. VI, ed. Ernst Dümmler (Berlin: Weidmann, 1925), 39.

51 Waitz, $A B, 41$. [...] pedestri itinere urbem Pictavorum adire moliuntur. Ibid., 46.Translation from Nelson, Annals of St. Bertin, 81.

52 Coupland, "Carolingian Army," 68-69.

53 See, for example, Ermentar, “MSF," 67; Waitz, AB, 84; Kurze, $A F, 97$.

54 Kurze, RP, 118; Pertz, “AV,” 200.

$55[\ldots]$ omnemque circumquaque regionem devastantes [...]. Kurze, RP, 76.Translation from MacLean, Chronicle of Regino, 133.

56 See, for example, Pertz, “AV,” 201, 203; Kurze, AF, 104. Vinitor agricolaeque [...] ferunt crudeles mortis habenas. Text and translation from Abbo, BPU, 38-39.

57 Kurze, $A F, 96-97$. [...] palatia quoque regum et villas, cum habitatoribus terrae interfectis [...]. Pertz, "AV," 199. 
58 Waitz, $A B, 52$; Calendarium, MS Thott $2392^{\circ}$, Royal Library, Copenhagen, fol. 10r. See also note 126.

59 Pertz, "AFont," 301.

60 “TSG," 80; Waitz, $A B, 43,75,80$.

61 Pertz, “AX,” 230; Pertz, “AV,” 199; Kurze, AF, 97; Kurze, RP, 138.

62 Waitz, $A B, 41$, 43; Kurze, $A F, 97$.

63 See, for example, Waitz, $A B, 35,61$; Kurze, $A F, 36,39$.

64 Waitz, $A B$; O. Holder-Egger, ed., "Miracula sancti Bertini Sithiensia," in MGH SS XV-I (Hannover: Hahn, 1887), 509.

65 Lupus Servatus, "Epistolae," 105. [...] Biorzuna, ubi pars maxima Frisonum habitabat [...]. Kurze, AF, 96. Translation from Reuter, Annals of Fulda, 89.

$66[\ldots]$ diuque optato fruerentur portu. "TSG," 72.

$67[\ldots]$ negotiatores quoque per Sequanam navigio sursum versus fugientes insecuntur et capiunt. Waitz, $A B, 54$. [...] villam non modicam, ad quam Frisii confugerant [...]. Ibid., 61. Translations from Nelson, Annals of St. Bertin, 94, 104.

$68[\ldots]$ Nortmanni [...] sollicitati paucarum civitatum vel regionum direptione, ex preda singularum, quantae opes universarum essent, animo prospicientes. Kurze, RP, 105-106. Translation from MacLean, Chronicle of Regino, 168.

69 The hazards of this competitive overexploitation are discussed in Kurrild-Klitgaard and Svendsen, "Rational Bandits," 256-259.

70 A conservative estimate based on five hours of daily rowing at an average upstream speed of two knots $(\approx 3.7 \mathrm{~km} / \mathrm{h})$ under oar, as provided by Gillmor, "War on the Rivers," 99. The $A B$ affirm that intermediate incursion took place en route to both targets. Waitz, $A B, 32$.

71 Ibid., 153; Kurze, $A F$, 97; Kurze, RP, 133.

72 [...] a tertio Idus Octobris usque Nonis Iunii dies ducentos octoginta septem. Pertz, "AFont," 303.

73 [...] decreverunt Luviano sibi sedem firmare ad hiemandum [...]. Pertz, "AV," 205. [...] ibique tota demorantes aestate, praedas agebant, nullo sibi resistente. Ibid., 208.

74 Namque, tametsi piratarum huc difficilis videtur accessus - quibus iam [...] nihil longinquum non est propinquum, nihil arduum est invium [...]. Lupus Servatus, "Epistolae," 94-95. Translation from Graydon W. Regenos, trans., The Letters of Lupus of Ferrières (The Hague: Martinus Nijhoff, 1966), 110.

75 The distance between Aachen and the Meuse is roughly twenty-seven km (as the crow flies), which would have taken a rider less than two hours to traverse at an average pace (c. $15 \mathrm{~km} / \mathrm{h})$. A contingent on foot would have been able to travel up to forty $\mathrm{km}$ a day, depending on group size, amount of baggage carried, as well as weather and terrain conditions. Travel speeds from Norbert Ohler, The Medieval Traveller, trans. Caroline Hillier (Woodbridge: Boydell, 1989), 101.

76 Pertz, "AEng," 486. See also Winroth, Age of the Vikings, 17.

$77[\ldots]$ non reperto exercitu qui contra eos bella committeret [...]. "TSG," 72. See also Waitz, AB, 32, 46; Pertz, “AV," 208.

78 [...] infirmitas nostri loci et exiguitas hominum, qui sint idonei resistere, accendit rapacium aviditatem [...]. Lupus Servatus, "Epistolae," 95. Translation from Regenos, Letters of Lupus, 110.

$79[. .$.$] non solum ex vicinis regionibus et vicis, sed etiam ex procul positis urbibus attraxerat$ [...]. Angers Miscellany, MS 817, Municipal Library, Angers, fol. 135v.

80 Pertz, “AFont," 302. 
81 Waitz, AB, 43. [...] circa sollempnitatem sancti Petri Atrebatis venerunt [...]. Pertz, “AV," 199.

82 Ibid., 205, 208. In addition to conventional intelligence gathering, Scandinavian awareness of these ceremonial conventions may have originated with Christian apostates, two of whom - former monks - are attested by the $A B$ to have joined regional viking hosts. See Waitz, $A B, 67,107$.

83 Pertz, "AFont," 302; Waitz, $A B, 52$. Dawn incursions are similarly attested at Quentovic (842) and Paris (845). Ibid., 28; “TSG,” 80.

84 Pertz,"AV," 201. [...] oppidanis siti arescentibus [...]. Kurze, RP, 135. Translation from MacLean, Chronicle of Regino, 208.

85 [...] obsidione pertaesi, fame attenuati, mortibus etiam suorum afflicti [...]. Pertz, "AV," 204.

86 Hiems asperrima. Waitz, AB, 32. Nimia inundatione aquarum [...]. Pertz, "AX," 230.

87 Sawyer,"Viking Expansion," 110; Nelson, "Frankish Empire," 24-25.

88 [...] illorum discordia addit vires extraneis [...]. Ermentar, "MSF," 60.

89 McKitterick, Frankish Kingdoms, 234.

90 Price, The Vikings in Brittany, 26; Nelson, Charles the Bald, 144, 154; Searle, Norman Power, 25. See also Section III.1.1.

$91[\ldots]$ indicat [...], discordiam amplectentibus qui fructus maneat, manifestat. Lupus Servatus, "Epistolae," 39. Translation from Regenos, Letters of Lupus, 61.

92 Nelson, Charles the Bald, 181; Gillmor, "War on the Rivers," 104.

93 Sawyer, "Viking Expansion," 113.

94 [...] Nortmanni [...], eorum audientes discordiam, [...] cum infinita multitudine mare transito [...]. Pertz,"AV," 197.

95 Nordmanni audita Francorum dissensione et imperatoris eorum abiectione plurima loca, quae prius minime tetigerant, vastaverunt. Kurze, $A F, 107$. Translation from Reuter, Annals of Fulda, 104.

96 Ernest Müller, ed., Nithardi historiarum libri IIII,MGH SR G XLIV (Hannover: Hahn, 1907), 42.

97 Dani qui pridem Morinum civitatem incenderant de Anglis revertentes [...]. Waitz, AB, 55. Translation from Nelson, Annals of St. Bertin, 95. [...] Nortmanni [...] mare transito [...]. Pertz, "AV," 197. The 861 attack may have been perpetrated by the same host that crossed the Channel during the previous year. See Waitz, $A B, 53-54$.

98 [...] oper dęl east, oper dęl to Hrofesceastre [...]. Bately, ASC (A), 52. Translation from Michael Swanton, trans., The Anglo-Saxon Chronicle (London: J.M. Dent, 1996), 79.

99 Bately, ASC (A), 55.

100 Pertz, “AV," 201, 206.

$101[. .$.$] Ruodoldus, [...] qui transmarinas regiones plurimas [...] vastavit [...]. Pertz, "AX,"$ 235. For Hasting, see, for example, Waitz, AB, 153; Pertz, “AV,” 199, 205; Bately, ASC (A), 55-56., as well as Nelson, "England and the Continent," 24-25.

102 Mary Valante, The Vikings in Ireland (Dublin: Four Courts, 2008), 55; Julian Richards, Viking Age England, 2nd ed. (Stroud: Tempus, 2000), 27-29; Wormald, "Viking Studies," 137. Ben Raffield and Neil Price likewise suggest the 'Great Army' to have been a conglomorate of numerous autonomous viking hosts. See Ben Raffield, "Bands of Brothers," 324-330; Price, "Ship-Men,” 57.

103 Clare Downham, Viking Kings of Britain and Ireland: The Dynasty of Ívarr to A.D. 1014 (Edinburgh: Dunedin, 2007), 25-27; Richards, Viking Age England, 29.

$104[\ldots]$ quis aestimare potuisset quod tam gloriosum regnum tamque munitum et latissimum, tam populosum et firmissimum talium hominum humiliari nel foedari sordibus deberetur? 
Et non dico hi quod censum plurimum asportare et predas diripere uel captiuos transducere, uerum quis credere potuisset quod tam uilissimi nostros adire fines auderent? Paschasius Radbert, Expositio in Lamentationes Hieremiae libri quinque, ed. Paulus Beda (Turnhout: Brepols, 1988), 281-282 (= ELH). Here, Paschasius - a contemporary theologian - lamented the 845 attack on Paris, which he characterised as a Frankish 'Jerusalem'.

105 Iterum pyratae Danorum alii mediante Augusto Sequanam ingrediuntur, et vastatis direptisque ex utraque fluminis parte civitatibus, etiam procul positis monasteriis atque villis [...]. Waitz, AB, 46. Translation from Nelson, Annals of St. Bertin, 82.

106 A dearth of further contemporary perspectives prevents these proceedings from being effectively cross-referenced, although a connection may be drawn to regional attacks in the preceding year. See Pertz, "AFont," 304.

107 Gentilitas vero consueto ab aquilone christianitatem nocuit, magis magisque convaluit; sed fastidiosum est enarrare. Pertz, "AX," 229. The ambiguity of this statement suggests that the annalist may have been unaware of the expedition's finer points.

108 Tanta enim egerunt, quanto nemo prudentium chronographorum enarrare sufficeret; idcirco multa reliqui, quia sub brevitate narrare disposui. Pertz, "AFont," 303-304.

109 Winroth, Age of the Vikings, 20.

110 [...] velut inmanis tempestas cuncta prosternit [...]. Kurze, RP, 67. Translation from MacLean, Chronicle of Regino, 133.

111 Waitz, $A B, 47$. It should also be pointed out that no significant fire damage from this period has been archaeologically attested around the basilica of St. Martin. See Hélène Noizet, "Les chanoines de Saint-Martin de Tours et les Vikings," in Les fondations scandinaves en Occident et les débuts du duché de Normandie, ed. Pierre Bauduin (Caen: CRAHM, 2005), 56-57.

112 Waitz, AB, 29; Pertz, "AEng," 486; Pertz, "AFont," 302; Ermentar, "MSF," 5960; Angers Miscellany, MS 817, Municipal Library, Angers, fols. 135r-136v. The lattermost of these sources contains two distinct accounts of the attack, both of which are thought to be contemporary. See Coupland, "Vikings on the Continent," 191.

113 Nordmanni per alveum Rheni fluminis ascendentes plurima loca nuper restaurata succenderunt, praedam inde capientes non modicam. Kurze, AF, 100. Translation from Reuter, Annals of Fulda, 95.

114 Although consistently attributed to malice, it is not inconceivable for some fires to have been accidentally started during an incursion. See also d'Haenens, Les invasions normandes, une catastrophe?, 106. In rare instances in which vikings were caught with their spoils, these do not seem to have been returned to their rightful owner, but divided among the troops that encountered them. Kurze, AF, 86, 102103. See also Timothy Reuter, "Plunder and Tribute in the Carolingian Empire," Transactions of the Royal Historical Society 35 (1985): 79.

$115[\ldots]$ reliquumque apparatum ecclesiae [...] destruere coeperunt."TSG," 80 . See also Waitz, $A B, 33$.

116 [...] omnia quae intus aut foris sanctuarii repperierunt, rapuerunt. Pertz, "AX," 230-231.

117 S. Muller and A.C. Bouman, eds., Oorkondenboek van het Sticht Utrecht tot 1301, vol. 1 (Utrecht: Oosthoek, 1920), 78; Van Vliet, “Traiecti Muros Heu: The Bishop of Utrecht during and after the Viking Invasions of Frisia (834-925)," 148, 152. See also Section VI.4.2.1.

118 Verhaeghe, "Urban Developments," 271.

119 Lebecq, "Role of Monasteries," 127-133. See also Section III.2.1. 
$120[\ldots]$ monasterium incendunt [...]. Waitz, $A B, 41$. The inventory may be found in Bischoff, Mittelalterliche Schatzverzeichnisse, I:38-39.

121 Jacques le Maho, "Les fouilles de la cathédrale de Rouen de 1985 à 1993: esquisse d'un premier bilan," Archéologie médiévale 24 (1994): 17-21. [...] Rotumam irruentes, rapinis, ferro ignique bachantes, urbem [...]. Waitz, $A B$, 25. Translation from Nelson, Annals of St. Bertin, 50.

122 Jacques le Maho, "Les Normands dans la vallée de la Seine (IX ${ }^{\mathrm{e}}-\mathrm{X}^{\mathrm{e}}$ siècles)," in Les Vikings en France: une synthèse inédite, vol. 277, Dossiers Archéologie (Dijon: Faton, 2002), 26-29.

123 Marcel Otte, "L'archéologie de la Place Saint-Lambert à Liège," in L'archéologie en région wallonne 1980-1990, ed. J. Barlet and J. Barthélémy (Commission Royale de Monuments, Sites et Fouilles, 1993), 96; Michiel H. Bartels and Michel Groothedde, "Central Places and Fortifications: The Case Study of Deventer and Zutphen - A Medieval Burgenordnung in the Eastern Netherlands?," in Trade and Communication Networks of the First Millennium AD in the Northern Part of Central Europe, ed. Babette Ludowici et al. (Hannover: Niedersächsisches Landesmuseum, 2010), 242-244, 246-247.

124 Ibid., 242-246.

125 Hugo Borger and Friedrich Oediger, Beiträge zur Frühgeschichte des Xantener Viktorstiftes (Düsseldorf: Rheinland-Verlag, 1969), 74-78.

126 Ronan Pérennec and Annie Bardel, "Landévennec: un monastère carolingien à la pointe de la Bretagne," in Landévennec: les Vikings et la Bretagne, ed. Magali Coumert and Yvon Tranvouez (Brest: Université de Bretagne Occidentale, 2015), 54-58. The Landévennec calendarium is partially preserved in the Royal Library in Copenhagen (cf. note 58).

127 Élisabeth Zadora-Rio and Henri Galinié, "Rigny-Ussé (Indre-et-Loire): Rigny," Archéologie médiévale 30-31 (2001): 227; Sébastien Jesset and Patrice Georges, "Sorigny (Indre-et-Loire): Nétilly," Archéologie médiévale 34 (2004): 203; Étienne Louis, "Wandignies-Hamage (Nord): ancienne abbaye," Archéologie médiévale 30-31 (2001): 278; Richard Nilles, "Marmoutier (Bas-Rhine): abbatiale Saint-Pierre et Saint-Paul," Archéologie médiévale 30-31 (2001): 409; Stéphane Venault, “Auxerre (Yonne): le site des archives départementales,” Archéologie médiévale 28 (1999): 214. See also Lesley Anne Morden, "How Much Material Damage Did the Northmen Actually Do to Ninth-Century Europe?” (PhD Diss., Simon Fraser University, 2007), 201-202, 207-208, 213-216.

$128[\ldots]$ coeperunt utriusque sexus populum captivare [...]. "TSG," 72. [...] gregibus captivorum utriusque ordinis sexus et aetatis [...]. Angers Miscellany, MS 817, Municipal Library, Angers, fol. 136r. [...] ingenti preda hominum [...]. Pertz, “AX,” 228.

129 Waitz, AB, 49. [...] Immonem episcopum cum aliis nobilibus, tam clericis quam laicis, capiunt [...]. Ibid., 52. Translation from Nelson, Annals of St. Bertin, 91. Gauzlin would later become bishop of Paris (880s).

130 Actardum Namnetice quondam sedis venerabilem episcopum, exilium, vinclum, mare, dura pericula passum, sed gratia dei liberatum [...]. Wilfried Hartmann, ed., Die Konzilien der karolingischen Teilreiche (860-874), MGH Conc. IV (Hannover: Hahn, 1998), 243 $(=$ CCEp $)$.

131 Angers Miscellany, MS 817, Municipal Library, Angers, fol. 136r. [...] secundum eorum placitum redempta fuerunt [...]. Waitz, AB, 81. Translation from Nelson, Annals of St. Bertin, 130.

132 Waitz, AB, 25; Pertz, “AFont,” 301. See also Nelson, "Frankish Empire," 26. 
$133[\ldots]$ plurimamque familiam trucidantes [...]. Kurze, RP, 138. Translation from MacLean, Chronicle of Regino, 212.

$134[\ldots]$ aliquos nobilium gratia pecuniae capere possent. Aimoin, "De miraculis sancti Germani," col. 1045.

135 [...] mater Evesa magno pretio dato incolumem recepit. Kurze, RP, 117. [...] multi thesaurorum ecclesiarum Dei ex regno Karli [...] exhausti sunt. Waitz, AB, 49. Translation from Nelson, Annals of St. Bertin, 86. A sum of 688 pounds of gold and 3,250 pounds of silver was paid by the St. Denis community, as described by a contemporary legal manuscript: Institutio et Regula canonicorum in concilio Aquisgranensi (816) editae, MS 789 (G. 599), Municipal Library, Rheims, fol. 106v.

$136[. .$.$] Hugo [...] graviter vulneratis ab hostibus rapitur [...]. Kurze, RP, 115. Translation$ from MacLean, Chronicle of Regino, 181. A similar fate may have befallen Count Robert of Anjou in 866: having been killed whilst attacking a viking host ensconced in a church at Brissarthe, his body was dragged inside by the besieged. See Waitz, $A B, 84$; Kurze, RP, 92-93.

137 Nelson, "Frankish Empire," 29; Waitz, AB, 48; Pertz, “AV,” 205.

138 [...] quos sive captivandi sive distrahendi [...]. Angers Miscellany, MS 817, Municipal Library, Angers, fol. 135v. The merits of this particular account, which was also incorporated into the eleventh-century Chronicon Namnetense, are discussed in Coupland, "Vikings on the Continent," 191; Matthias Bley, "Viking Defilement in Early Medieval Francia," in Discourses of Purity in Transcultural Perspective (300-1600), ed. Matthias Bley, Nikolas Jaspert, and Stefan Köck (Leiden: Brill, 2015), 210. See also David Dumville, "Images of the Viking in Eleventh-Century Latin Literature," in Latin Culture in the Eleventh Century, ed. Michael Herren, C.J. McDonough, and Ross Arthur, vol. I (Turnhout: Brepols, 2002), 255-256.

$139[\ldots]$ servitoribusque divini cultus aut gladio aut fame peremptis, aut ultra maris venditis [...]. Pertz, “AV," 200.

140 [...] abductis, venditis [...]. Flodoard, "AFL," 368.

141 Interea stationem navium suarum acsi asylum omnium periculorum in insula quadam coenobio Sancti Florentii subposita conponentes, mappalia quoque instar exaedificavere burgi, quo captivorum greges catenis asstrictos adservarent [...]. Adrevald, "Miraculis sancti Benedicti," in MGH SS XV-I, ed. O. Holder-Egger (Hannover: Hahn, 1887), 494. Translation from Coupland, "Vikings in Francia and Anglo-Saxon England," 196.

142 Georg Heinrich Pertz, ed., "Vita sancti Rimberti archiepiscopi Hammaburgensis," in MGH SS II (Hannover: Hahn, 1829), 773. The potential Carolingian origin of the slaves is suggested by McCormick, European Economy, 609.

$143[. .$.$] quietisque sedibus immorantur. Waitz, A B$, 33. Translation from Nelson, Annals of St. Bertin, 62. On one occasion, the same source also refers to a viking encampment on the Loire (868) as a diversorium, a term ordinarily applied to lodgingplaces for passing travellers. Waitz, $A B, 91$.

$144[\ldots]$ corpora a labore reficerent [...]. Adrevald, "MSB," 494. Translation by Coupland, "Vikings in Francia and Anglo-Saxon England," 196.

$145[\ldots]$ fessa ab itinere corpora recreantes $[\ldots]$. Kurze, $R P, 119$. Translation from MacLean, Chronicle of Regino, 186. This local anchorage seems to have lasted for only four days (Maundy Thursday to Easter Sunday).

$146[. .$.$] illorum naves statuerunt reficere et vernale aequinoctium exspectare [...]. Waitz, A B$, 57. [...] ad locum sibi aptum ad reficiendas suas et novas faciendas naves [...]. Ibid., 81. Translations from Nelson, Annals of St. Bertin, 98, 131.

147 Pertz, “AV,” 199. 
148 Although the commandeering of enemy vessels by vikings has been observed (see SectionVI.1.1.1), its precarious nature would have made this an unreliable method to reinforce fleet strength.

149 Jan Bill, "Nails," in Woodstown: A Viking-Age Settlement in Co. Waterford, ed. Ian Russell and Maurice Hurley (Dublin: Four Courts, 2014), 154; Dawn Hadley and Julian Richards, "The Winter Camp of the Viking Great Army, AD 872-3, Torksey, Lincolnshire," Antiquaries Journal 96 (2016): 53.

150 Pertz, "AFont," 304; Waitz, AB, 46-47.

$151[. .$.$] munitionem in eodem loco more solito construunt et in eo tota hieme resident. Kurze,$ $R P, 122$.

$152[\ldots]$ castraque metati sunt paene duobus milibus a sancto monasterio Rotonensi. Brett, "GSR," 217.

153 [...] in Haslao sibi sedem firmant ad hyemandum. Pertz, "AV," 199. See also Ibid., 205, 209; Kurze, AF, 119-120.

154 See, for example, Pertz, “AFont,” 304; Waitz, AB, 55, 116; Pertz, “AX,” 231.

155 Waitz, $A B, 47$; Kurze, RP, 106.

156 Brett, "GSR," 215. A number of Scandinavian armaments have also been recovered from the former island, which now forms part of the Île de Nantes. Arbman and Nilsson, "Armes scandinaves," 168-171.

157 Pertz, “AFont,” 304; Waitz, AB, 50, 55-56.

158 Pertz, “AX,” 231; Waitz, $A B, 61$.

159 Hadley and Richards, "Winter Camp," 31-36.

160 Waitz, $A B, 29$.

161 Jan Besteman, "Viking Silver on Wieringen," in In Discussion with the Past, ed. Herbert Sarfatij (Zwolle: SPA, 1999), 253-265; Jan Besteman, "Nieuwe Vikingvondsten van Wieringen: de zilverschat Westerklief II," in Middeleeuwse toestanden: archeologie, geschiedenis en monumentenzorg, ed. P.J. Woltering, W.J.H. Verwers, and G.H. Scheepstra (Hilversum: Verloren, 2002), 65-73.

162 Liliane Tarrou, "Les Vikings en Bretagne et en Loire-Atlantique à la lumière des vestiges matériels," in Les Vikings dans l'empire franc, ed. Élisabeth Ridel (Bayeux: OREP, 2014), 36; Neil Price, "Viking Brittany: Revisiting the Colony That Failed," in Early Medieval Art and Archaeology in the Northern World, ed. Andrew Reynolds and Leslie Webster (Leiden: Brill, 2013), 737; Jean Renaud, Les Vikings en France (Rennes: Ouest-France, 2000), 96.

163 Respective arguments for and against the identification of this structure as a viking encampment have been advanced by Loïc Langouët, "Un retranchement normand 'insulaire': Gardaine à Saint-Suliac (Ille-et-Vilaine)," Bulletin de l'AMARAI 4 (1991): 55-63; Hubert Guillotel, "Saint-Suliac: rencontre de l'archéologie, de la diplomatique, du droit et de l'hagiographie," Mémoires de la Société d'histoire et d'archéologie de Bretagne 76 (1998): 5-25.

164 Élisabeth Ridel, "Sur la route des Vikings: les îles anglo-normandes entre Bretagne et Normandie," in Landévennec: les Vikings et la Bretagne, ed. Magali Coumert and Yvon Tranvouez (Brest: Université de Bretagne Occidentale, 2015), 154-155. The name may also be cognate with 'Jobourg', found near the northern tip of the Cotentin Peninsula.

165 [...] conati sunt fluvium a suo alveo dirivare, ut exsiccato naturali meatu naves Nortmannorum invadere possent. Ceperunt itaque fossam mirae profunditatis ac latitudinis aperire; quae res tantum formidinis metum Nortmannis ingessit, ut [...] ingentem pecuniam 
Carolo pollicerentur, si soluta obsidione eis [...] liberum preberet egressum. Kurze, RP, 106. Translation from MacLean, Chronicle of Regino, 169.

166 Kurze, AF, 119-120; Kurze, RP, 137. See also Halsall, Warfare and Society, 186-187.

167 See, for example, Kurze, $A F, 96,107,119$; Abbo, BPU, 66. Early eleventh-century Norman historian Dudo affirmed such circular earthworks to have been visible in the landscape during his lifetime, although his account is considered to be unreliable. See Dudo, De moribus et actis primorum Normannice ducum (Caen: Blanc-Hardel, 1865), 155, as well as note 201.

168 Kurze, $R P, 126,137$; Abbo, $B P U, 36$.

169 Kurze, $R P, 126$; Kurze, $A F, 99$.

170 Maurice Hurley, "Discussion and Conclusions," in Woodstown: A Viking-Age Settlement in Co. Waterford, ed. Ian Russell and Maurice Hurley (Dublin: Four Courts, 2013), 348; Williams, "Viking Camps," 97; John Sheehan, "The Longphort in Viking Age Ireland," Acta Archaeologica 79 (2008): 283-284. As previously pointed out (note 159), some viking camps in Britain and Ireland would have had very different morphological characteristics, as in the case of the effectively insular outpost at Torksey. See Hadley and Richards, "Winter Camp," 31-36.

171 Mazet-Harhoff, "Incursion of the Vikings," 107.

172 Ben Raffield has suggested similarly dispersed viking encampment to have taken place in Anglo-Saxon England. Raffield, "Bands of Brothers," 323-324.

173 Kurze, $R P, 106$.

$174[. .$.$] quia palatium a ingentis magnitudinis mirique operis hostibus tutissimum prebebat$ receptaculum. Ibid., 117. Translation from MacLean, Chronicle of Regino, 184. See also Kurze, $A F, 96$. The occupation of Trier is referenced by Kurze, $R P, 119$.

175 Waitz, $A B$, 56-57, 80; Mazet-Harhoff, "Incursion of the Vikings," 105.

176 Martin Biddle and Birthe Kjølbye-Biddle, "Repton and the Vikings," Antiquity 66 (1992): 40; Williams, "Viking Camps," 97.

177 Circumeunt castris aequor, sed et undique vallo / Clauditur, a, dominusque meus, quasi carcere latro [...]; murus circumdedit eius / Ecciesiam [...]. Text and translation from Abbo, BPU, 66-67.

$178[\ldots]$ post multam depraedationem sine contra dictione cuiusquam ad castra sua [...] sunt reversi. Waitz, $A B, 80$. Translation from Nelson, Annals of St. Bertin, 128.

$179[\ldots]$ vicinia quaeque depopulantes [...]. Waitz, AB, 75. Translation from Nelson, Annals of St. Bertin, 122. Two of these expeditions took place in 865, the others in 866 and 868, respectively. See Waitz, $A B, 75,79,80,91$.

180 Pertz, “AV," 199.

181 Nam cum ad quandam insulam Saequanae pagani crudelissimi pyratae applicuissent, quae sita est sub Melleduni oppido [...] et eorum viciniam nobis, ut erat, periculosissimam, nisi Dei miseratio subveniret, duceremus [...]. Lupus Servatus, "Epistolae," 105. Translation from Regenos, Letters of Lupus, 135.

182 Adrevald, "MSB," 494. See also Section VI.1.3.

183 The construction of slave enclosures is referenced in Adrevald, "MSB," 494. See also note 141.Abbo, $B P U, 86$, likewise mentions slaves held within Scandinavian camps.

184 The local production of various armaments and siege weapons is referenced in Ibid., 38-40; Pertz, “AV,” 204. For the Insular evidence, see, for example, Williams, "Viking Camps," 105; Eamonn Kelly,"The Longphort in Viking-Age Ireland: The Archaeological Evidence," in The Vikings in Ireland and Beyond: Before and After the Battle of Clontarf, ed. Howard Clarke and Ruth Johnson (Dublin: Four Courts, 2015), 62, 68, 83-84. 
185 Hydrarchies may have also pooled their expertise and resources to tackle more complex and labourious construction projects.

186 Petierunt autem, ut eis in quadam insula Ligeris fluvii usque in mense Februario residere et mercatum habere liceret [...]. Waitz, AB, 124. Translation from Nelson, Annals of St. Bertin, 185.

187 Kurze, $A F, 98$.

188 This type of local exchange is suggested to have been an equally established feature of viking encampments across Britain and Ireland, as evidenced, for example, by the respective assemblages from Woodstown, Torksey, and the hitherto unspecified riverine site at Aldwark near York ('ARSNY'). See Williams, "Viking Camps," 99.

189 A reference to Scandinavians reaping and sheafing crops near St. Germain-desPrés (886) is made in Abbo, BPU, 68.

190 Jean-Pierre Nicolardot and Phlippe Guigon, "Une forteresse du X siècle: le camp de Péran à Plédran (Côtes d'Armor)," Revue archéologique de l'Ouest 8 (1991): 137.

191 Efficitur bostar Germani antistitis aula, / Completur tauris, suculis simisque capellis. Text and translation from Abbo, BPU, 62-63.

192 "TSG," 72. [...] fruges diversi generis congregates [...]. Kurze, AF, 102. Translation from Reuter, Annals of Fulda, 97.

193 Michel Groothedde, "De nederzettingsontwikkeling van Zutphen voor het jaar 1000," in De Sint-Walburgiskerk in Zutphen: momenten uit de geschiedenis van een middeleeuwse kerk (Zutphen: Walburg, 1999), 22.

194 Williams, "Viking Camps," 115-116.

$195[\ldots]$ multa pensione farinae atque pecorum necnon vini ac sicerae [...]. Waitz, AB, 67. Translation from Nelson, Annals of St. Bertin, 112. See also Kurze, RP, 108.

196 Waitz, AB, 79; Halsall, Warfare and Society, 37.

197 See, for example, Forte, Oram, and Pedersen, Viking Empires, 60; Winroth, Age of the Vikings, 16.

198 Ad postremum insulam quandam ingressi, convectis a continenti domibus, hiemare velut perpetuis sedibus statuerunt. Waitz, AB, 29. Translation from Nelson, Annals of St. Bertin, 56. A passage from the eleventh-century Chronicon Namnetense, affirming a short-lived viking presence on Noirmoutier at this time, is not considered to be reliable. See René Merlet, ed., Chronique de Nantes (Paris: Picard et Fils, 1896), 19-20.

199 [...] inferioris partes Aquitaniae [...]. Translated as 'western parts of Aquitaine' by Nelson (Nelson, Annals of St. Bertin, 56.), presumably interpreting inferioris as 'downstream'. See also Coupland, "Vikings on the Continent," 186-187.

200 [...] Nortmanni Burdegalim urbem ceperunt et ducem eiusdem Guilhelmum [...]. Pertz, "AFont," 302.

201 [...] munimen [...] quod apparet ad tempus usque istius diei. Dudo, Normannice ducum, 155. Translation from Eric Christiansen, trans., History of the Normans (Woodbridge: Boydell, 1998), 36-37.

202 Cyril Marcigny, "Le rempart du « Hague Dike »: une limite territoriale de l'âge du Bronze," Archéologie, histoire et anthropologie de la presqu'île de la Hague 10 (2016): 2735 . Whilst also originally associated with local viking activity, the supposed stone ship burials at nearby Réville have since been identified as the vestiges of Bronze Age burial mounds. See Michel de Boüard, "Sépultures énigmatiques á Réville (Manche)," Annales de Normandie 14, no. 2 (1964): 263; Vincent Carpentier and Cyril Marcigny, "L'imaginaire archéologique dans les représentations du 
phénomène viking en Normandie: faux ou usages de faux?," in Les Vikings dans l'empire franc, ed. Élisabeth Ridel (Bayeux: OREP, 2014), 98.

203 Société des antiquaires de Normandie, Mémoires de la Société des antiquaires de Normandie, vol. IX (Caen: Hardel, 1835), 197-198, Atlas: VII; Mazet-Harhoff, "Incursion of the Vikings," 105.

204 Fellows-Jensen, "Place-Names and Settlement," 118-127.

205 Jean Renaud, Les Vikings et la Normandie (Rennes: Ouest-France, 1989), 195-198; Le Maho, "Fate of the Ports," 241-244.

206 Mazet-Harhoff, "Incursion of the Vikings," 103.

207 Brett, "GSR," 215; Adrevald, "MSB," 494; Waitz, AB, 61; Coupland, "Poachers to Gamekeepers," 98, 101.

208 Kurze, RP, 92, 108; Waitz, AB, 154.

209 [...] palatium [...] cum munitione flammis exurentes [...]. Kurze, RP, 117-118. Translation from MacLean, Chronicle of Regino, 184.

210 Pertz, “AV," 201; Kurze, RP, 122.

211 [...] velut perpetuis sedibus [...]. Waitz, $A B, 29$. The encampment at Jeufosse is mentioned between 852 and 856 (Pertz, "AFont," 304; Waitz, AB, 46-47.). MazetHarhoff has stated that it may have been in use until well into the early tenth century, although his rationale for this assumption is unclear. See Laurent MazetHarhoff, "Sur la trace des Vikings en Haute-Normandie: problématique," in La progression des Vikings, des raids à la colonisation, ed. Anne-Marie Flambard Héricher (Rouen: Université de Rouen, 2003), 129. For the camp at Oissel, see Pertz, "AFont," 304; Waitz, $A B, 55$.

212 Ibid., 74, 79, 91, 116.

213 Besteman, "Wieringen: Westerklief II," 73.

214 Having been routed at Saucourt-en-Vimeu in 881, the survivors of a large viking army reported the outcome of the battle to their camp (presumably at Courtrai), which would have retained a local skeleton garrison. Pertz, "AV," 199. Outposts occupied by successive groups include Jeufosse $(852,856)$ and Louvain $(884,891)$.

215 Boretius and Krause, "EP," 321-322.

216 Alfred Boretius and Victor Krause, eds., "Edictum Compendiense de tributo Nordmannico," in MGH Capit. II (Hannover: Hahn, 1897), 354; Boretius and Krause, eds., "Capitulare Carisiacense," in MGH Capit. II, 361.

217 Inter cetera retulit [...] narrando quam bonam quamque fertilem ac omnibus repletam copiis invenisset terram, et quod nullam ei similem unquam reperisset, sed populum ipsam incolentem, plus omnibus aliis ad dimicandum trementem ac pavidum. "TSG," 92.

$218[\ldots]$ illorum discordia addit vires extraneis; [...] torpentes atque invicem dissidentes, quod defendere debuerant armis, tributis redimunt, ac Christianorum pessumdatur regnum. Ermentar, "MSF," 60-62.

219 [...] terram quidem vastavit, sed nullius utilitatis effectum ex Nortmannis, ad quos resistendum missa fuerat [...]. Waitz, AB, 97. Translation from Nelson, Annals of St. Bertin, 152.

$220[\ldots]$ sed nihil dignum memoriae [...] actum est. Kurze, RP, 122. Translation from MacLean, Chronicle of Regino, 191.

221 Observations of inefficacy are, for example, also found in Pertz, "AV," 196, 197, 200, $201,205$.

$222[\ldots]$ silvis se occuluerent [...]. Pertz, "AFont," 303.

$223[. .$.$] possint advolare, nulla munitione, nulla hominum obstante frequentia et vicinia saltuum recepti$ sic diversi diffugere, ut ipsi pecunia securi potiantur, inanem laborem inquirentibus derelinquant. Lupus Servatus, “Epistolae,” 95. Translation from Regenos, Letters of Lupus, 110. 
$224[\ldots]$ in silvis et paludibus Aquis palatio contiguis disperguntur, [...]. Kurze, RP, 136. Translation from MacLean, Chronicle of Regino, 210. See also Halsall, Warfare and Society, 151.

$225[\ldots]$ per invia loca parant redire ad castra. Pertz, "AV," 205.

226 Several unsuccessful Carolingian attempts to use naval force against vikings are listed by Coupland,"Carolingian Army," 63-64.A singular success story is disclosed by the $A F$ for 885 , when Frisian mariners - using small vessels - assisted in subduing a Scandinavian fleet. Kurze, $A F, 102-103$.

227 Kurze, $R P, 106$; Kurze, $A F, 96$.

228 Ibid., 120.

229 [...] Danorum [...] numquam antea in aliqua munitione vel capta vel superata auditur. Ibid. Translation from Reuter, Annals of Fulda, 122. Prior viking defeats had, for example, taken place at encampments on the Rhine (863) and in the Hesbaye (885). Pertz, “AX,” 231; Kurze, AF, 102.

230 [...] adeo profligati sunt, ut ultra trecentos pauci evaserint. Waitz, AB, 46. [...] amplius quam quingentos sine dampno suorum occidens [...]. Ibid., 79.Translations from Nelson, Annals of St. Bertin, 81, 127.

231 Kurze, $A F$, 94; Pertz, “AV,” 199; Abbo, BPU, 90. For a more comprehensive survey, see Coupland, "Carolingian Army," 66-67.

232 See, for example, Abbo, BPU, 64; Kurze, AF, 103.

233 McKitterick, Frankish Kingdoms, 235.

$234[\ldots]$ cum incautius dimicaret et inimicos ultro insequeretur [...]. Kurze, RP, 92. Translation from MacLean, Chronicle of Regino, 154.

$235[\ldots]$ incaute cum paucis occurrens occisus est. Kurze, AF, 98. Translation from Reuter, Annals of Fulda, 91.

$236[\ldots]$ quia nihil utilitatis contra Nortmannos egerant $[\ldots]$. Waitz, AB, 80. Translation from Nelson, Annals of St. Bertin, 129.

237 Vulgus promiscuum [...] inter se coniurans, adversus Danos in Sequana consistentes fortiter resistit. Waitz, $A B, 51$. [...] resistentibus sibi pagensibus [...]. Ibid., 72. Translations from Nelson, Annals of St. Bertin, 89, 118.

238 Waitz, $A B$, 87; Kurze, $R P, 118,133$, 134-135. See also McKitterick, Frankish Kingdoms, 232.

239 A potential reference to the establishment of coastal garrisons (884) is found in Kurze, $A F, 101$.

$240[\ldots]$ deseritur custodia litorum maris Oceani; [...] augescit numerus navium, crescit innumerabilis multitudo Nortmannorum, [...]. Ermentar, "MSF," 60.

241 Vercauteren, "Comment s'est-on défendu," 118-120.

242 Karolus [...] civitates [...] firmari rogavit [...] ut praesidio contra Nortmannos populis esse possent [...]. Waitz, AB, 107. Translation from Nelson, Annals of St. Bertin, 164.

$243[\ldots]$ muri eius cum portis et vectibus et seris instaurati. Kurze, $A F, 100$. Translation from Reuter, Annals of Fulda, 95. The refurbishment of Paris' defences is referenced in Pertz, “AV," 201.

$244[\ldots]$ iam monasterio muris circumsepto, turribus offirmato, vallorum ambitu circumdato [...]. O. Holder-Egger, ed., "Sermo de relatione corporis beati Vedasti," in MGH SS XV-I (Hannover: Hahn, 1887), 402. For St. Denis, see Waitz, AB, 98. Excavations at St. Denis have confirmed the presence of a ninth-century fortification, consisting of a rampart and encircling moat. Michaël Wyss, "Un établissement carolingien mis au jour à proximité de l'abbaye de Saint-Denis: la question du palais de Charlemagne," in "Aux marches du Palais". Qu'est-ce qu'un palais médiéval?, ed. Annie Renoux (Caen: Société d’Archéologie Médiévale, 2001), 195-196. 
245 Arnaud Prié, "Paris (Seine). 15, Rue du Temple (III Arr.)," Archéologie médiévale 28 (1999): 283-284.

246 Annie Renoux, "Karolingische Pfalzen in Nordfrankreich (751-987)," in 799 Kunst und Kultur der Karolingerzeit, ed. Christoph Stiegemann and Matthias Wemhoff, vol. III (Mainz: von Zabern, 1999), 135-136.

247 F. Blary and V. Blary, "Château-Thierry (Aisne): 'le vieux château," Archéologie médiévale 23 (1993): 418; Michiel Bartels, De Deventer wal tegen de Vikingen (Deventer: Gemeente Deventer, 2006), 62-65; Michel Groothedde, “The Vikings in Zutphen (Netherlands)," in Vikings on the Rhine: Recent Research on Early Medieval Relations between the Rhinelands and Scandinavia, ed. Rudolf Simek and Ulrike Engel (Vienna: Fassbaender, 2004), 121-126. In nearby Tiel, the vestiges of a late ninth- to early tenth-century circular embankment have likewise been associated with regional viking endeavour. J.W.M. Oudhof, A.A.A. Verhoeven, and I. Schuuring, Tiel rond 1000: analyse van vier opgravingen in de Tielse binnenstad (Amsterdam: Amsterdam University Press, 2013), 25-26.

248 Günther Binding, "Spätkarolingisch-Ottonische Pfalzen und Burgen am Niederrhein," Château Gaillard: études de castellologie médiévaleV (1972): 25-30.

249 Philippe Racinet, "Une résidence carolingienne sur 'motte' (avant le dernier quart du $\mathrm{X}^{\mathrm{e}}$ siècle): phases $2 \mathrm{~A}$ et $2 \mathrm{~B}$," in Le site castral et prioral de Boves $d u X^{e}$ au XVII siècle, Revue Archéologique de Picardie, Numéro Spécial 20 (Senlis, 2002), 42; Benjamin Saint-Jean Vitus, "Tournus du castrum antique au bourg médiéval: paysage monastique et développement urbain," in Saint-Philibert de Tournus: histoire, archéologie, art, ed. Jacques Thirion (Tournus: Centre International d'Etudes Romanes, 1995), 387, 395n13.

$250[\ldots]$ quicumque istis temporibus castella et firmitates et haias sine nostro verbo fecerint, [...] omnes tales firmitates disfactas habeant, [...]. Boretius and Krause, "EP," 328. Whereas the use of castellum and firmitas pertains to fortifications in general, haia (or haga) signifies palisades in particular.

251 Nelson, "Frankish Empire," 44; Charles Coulson, "Fortresses and Social Responsibility in Late Carolingian France," Zeitschrift für Archäologie des Mittelalters 4 (1976): 32.

252 Vercauteren, "Comment s'est-on défendu," 131-132; Michel Rouche, "The Vikings versus the Towns of Northern Gaul: Challenge and Response," in Medieval Archaeology, ed. Charles Redman (Binghamton: Center for Medieval and Early Renaissance Studies, 1989), 50.

253 See, for example, Abbo, BPU, 32, 62.

254 Holder-Egger, "MSBr," 512-514.

255 Angers Miscellany, MS 817, Municipal Library, Angers, fol. 135v; Pertz, “AV,” 201. For the ninth-century fortification of Rouen, see Le Maho, "Cathédrale de Rouen," 26; Mazet-Harhoff, "Incursion of the Vikings," 112-113.

256 Waitz, AB, 153; Pertz, “AV,” 198; Kurze, RP, 133; Päffgen, "Urban Settlements,” 88.

257 Civitates vero quaedam turribus firmae non potuerunt episcoporum suorum servare vitam. Hildegar, "VF," 200.

$258[. .$.$] pontem ad insulam secus Treiectum reficit et Normannis descendendi aditum intercludit$ [...]. Waitz, AB, 57. Translation from Nelson, Annals of St. Bertin, 98.

$259[\ldots]$ in Sequana munitiones construens, ascendendi vel descendendi navibus propter Nortmannos aditum intercludit. Waitz, AB, 58. Translation from Nelson, Annals of St. Bertin, 100 . 
260 Waitz, AB, 79. [...] ex ligno et lapide [...]. Ibid., 98. Simon Coupland, “The Fortified Bridges of Charles the Bald,” Journal of Medieval History 17 (1991): 4-9.

261 Brian Dearden and Anthony Clark, "Pont-de-l'Arche or Pîtres? A Location and Archaeomagnetic Dating for Charles the Bald's Fortifications on the Seine," Antiquity 64, no. 244 (1990): 569-570. The bridgehead design may have inspired similar riverine defences on the Thames during the tenth century (Loveluck, Northwest Europe, 219.). The design of the bridge is briefly discussed by Halsall, Warfare and Society, 219-220.

262 [...] lapidumque salire struem super altam / Flammivomas puppes, pontem ne lederet ulla, / Ipse coegisti; pontem sustentat is agger. Text and translation from Abbo, BPU, 50-51. An earlier diploma of Charles, alluding to the fortification of the bridge during the early 860 s, is considered to be a forgery. See Georges Tessier, ed., Recueil des actes de Charles II le Chauve, roi de France, vol. II (Paris: Imprimerie Nationale, 1952), 612; Coupland, "Fortified Bridges," 11n4.

263 Boretius and Krause, "CC," 361.

264 Boretius and Krause, "EP," 321-322.

265 Coupland, "Fortified Bridges," 7, 10.

266 Waitz, AB, 132, 134, 150; Pertz, “AV,” 201-202. Evidence of burning at Pont-del'Arche suggest that its bridgeheads were attacked sometime after its construction. See Dearden and Clark, "Pont-de-l'Arche or Pîtres?," 569.

267 See, for example, Kurze, $R P, 130,135$.

268 Sharing the Germanic appellative -burg, 'fortified place', most of these toponyms are first attested in various high-medieval sources. Maurits Gysseling, Toponymisch woordenboek van België, Nederland, Luxemburg, Noord-Frankrijk en West-Duitsland (vóór 1226) (Brussels: BIUCN, 1960), 206-207, 277, 696, 765; H.J. Moerman, Nederlandse plaatsnamen: een overzicht (Leiden: Brill, 1956), 45-46. Oostburg, however, already appears as castrum Osborch in a tenth-century charter. Maurits Gysseling and A.C.F. Koch, eds., Diplomata Belgica ante annum millesimum centesimum scripta (Brussels: BIUCN, 1950), 145.

269 Letty ten Harkel, "A Viking Age Landscape of Defence in the Low Countries? The Ringwalburgen in the Dutch Province of Zeeland," in Landscapes of Defence in Early Medieval Europe, ed. John Baker, Stuart Brookes, and Andrew Reynolds (Turnhout: Brepols, 2013), 228, 237, 240.

270 R.M. van Dierendonck, "The Early Medieval Circular Fortresses in the Province of Zeeland, The Netherlands: Ten Years After," in Ringwälle und verwandte Strukturen des ersten Jahrtausends $n$. Chr. an Nord- und Ostsee, ed. Martin Segschneider (Neumünster: Wachholtz, 2009), 252. As this external threat subsided, the ringwalburgen seem to have been repurposed for permanent occupation. Ibid., 257-258.

271 M.F.P. Dijkstra and Tim de Ridder, "Circular Fortresses in the Provinces of North and South Holland (West Frisia)," in Ringwälle und verwandte Strukturen des ersten Jahrtausends n. Chr. an Nord- und Ostsee, ed. Martin Segschneider (Neumünster: Wachholtz, 2009), 203, 206.

$272[\ldots]$ castella ibi recens facta [...]. Holder-Egger, "MSBr," 512. See also J. de Meulenmeester, "Castrale motten in België," Archaeologia Belgica 255 (1983): 201203; "Karolingische castra en stadsontwikkeling: enkele archaeo-topografische suggesties," in Ontstaan en vroegste geschiedenis van de middeleeuwse steden in de Zuidelijke Nederlanden (Brussels: Gemeentekrediet, 1990), 118-141. 
273 John Baker and Stuart Brookes, Beyond the Burghal Hidage: Anglo-Saxon Civil Defence in the Viking Age (Leiden: Brill, 2013), 386-391;Yorke, Kings and Kingdoms, 152.

274 Dries Tys, Pieterjan Deckers, and Barbora Wouters, "Circular, D-Shaped and Other Fortifications in 9th- and 10th-Century Flanders and Zeeland as Markers of the Territorialisation of Power(s)," in Fortified Settlements in Early Medieval Europe: Defended Communities of the 8th-10th Centuries, ed. Neil Christie and Hajnalka Herold (Oxford: Oxbow, 2016), 187-188; J.M. Hassall and David Hill, "Pont de l'Arche: Frankish Influence on the West Saxon Burh?," Archaeological Journal 127 (1970): 191-194. Jaques le Maho believes a network of fortified refuges to have been in place around the Seine during the end of the ninth century. Jacques le Maho, "La Seine et les Normands avant 911," in Naissance de la Normandie - 911: le traité de Saint-Clair-sur-Epte, ed. Michel Pierre (Paris: SPM, 2013), 27.

275 Throughout the later ninth and early tenth centuries, various royal land grants were issued for the explicit purpose of providing refuge for these embattled communities. See Coulson, "Fortresses," 31n19.

276 “TSG," 75, 85.

277 Pertz, "AX," 230-231; Daniel DeSelm, "Unwilling Pilgrimage: Vikings, Relics, and the Politics of Exile during the Carolingian Era (c. 830-940)" (PhD Diss., University of Michigan, 2009), 230-235.

278 Muller and Bouman, Oorkondenboek van het Sticht Utrecht tot 1301, 1:78. Hincmarus episcopus $[. .$.$] vix noctu [. .$.$] deportatus [. .$.$] . Waitz, AB, 154.Translation from Nelson,$ Annals of St. Bertin, 226.

279 Whenever their caretakers were forced to leave relics behind - constrained by urgency or carrying capacity - efforts may have been made to disguise or hide these objects. See Päffgen, "Urban Settlements," 105-106.

280 Waitz, $A B, 43,52$. For a more comprehensive overview of forced translations in Carolingian Neustria and Aquitaine, see DeSelm, "Unwilling Pilgrimage," 144190, 237-248.

281 [...] omnes intra Scaldum et Somnam atque trans Scaldum monachi, canonici, sanctimoniales, cum corporibus sanctorum, et omnis aetas et conditio fugam ineunt. Pertz, "AV," 198. Evacuations in the Rhineland are referenced in Kurze, $A F, 97$.

282 Le Maho, "Fate of the Ports," 236. Lay lamentation due to relic removal is noted, for example, around the Seine in 845. See "TSG," 75.

283 Ibid., 80; Kurze, RP, 106.

284 Anne Bocquet, Kristell Chuniaud, and Chuniaud Naveau, "Le quartier antique de la Grande-Boissière à Jublains (Mayenne)," Revue archéologique de l'Ouest 21 (2004): 171-172; Jean-François Martin, “Sissonne (Aisne). Jeoffrécourt," Archéologie médiévale 27 (1997): 265.

285 Simon Armstrong, "Carolingian Coin Hoards and the Impact of the Viking Raids in the Ninth Century," Numismatic Chronicle 158 (1998): 140-148, 157.The deposition of hoards as a result of internecine Carolingian conflict or owners leaving on campaign should not be discounted, however. See Ibid., 148-150.

286 Boretius and Krause, "EP," 323-324. This provision harkens back to a prior capitulary of Charles - formulated at Servais in 853 - which likewise legislated for the protection and repatriation of those displaced by viking and Breton incursions. See Alfred Boretius and Victor Krause, eds., "Capitulare missorum Silvacense," in MGH Capit. II (Hannover: Hahn, 1897), 273. 
287 [...] regni nostri maximum fit detrimentum [...] quicumque [...] Nortmannis quocumque ingenio vel pro redemptione vel pro aliquo pretio bruniam vel quaecumque arma aut caballum donaverit, sicut proditor patriae et expositor christianitatis ad perditionem gentilitati sine ulla retractione vel redemptione de vita componat. Boretius and Krause, "EP," 321.

288 Gillmor, "War on the Rivers," 104.

$289[\ldots]$ septem milium librarum eis exhibito, a progrediendo compescuit ac redire persuasit. Waitz, AB, 32. Translation from Nelson, Annals of St. Bertin, 60.

$290[\ldots]$ multa milia ponderum auri et argenti $[\ldots]$. Pertz, "AX," 228.

$291[. .$.$] regno suo, ne depraedaretur [...]. Waitz, AB, 55. Translation from Nelson, Annals$ of St. Bertin, 95. For the 866 payment, see Waitz, $A B, 81$.

292 As the use of the term Danegeld to identify Carolingian tribute payments remains contentious, it will here be avoided altogether. See Simon Coupland, "The Frankish Tribute Payments to the Vikings and Their Consequences," Francia 26 (1999): 57n5. Guy Halsall has suggested that, like fleet and army size, payment amounts may have been inflated by contemporary authors for rhetorical effect. Halsall, Warfare and Society, 123.

293 Reuter, "Plunder and Tribute," 75-76.

294 See, for example, Waitz, AB, 32; Kurze, AF, 108-109; Pertz, “AV,” 205.

295 [...] exactionem de thesauris ecclesiarum et omnibus mansis ac negociatoribus etiam paupertinis [...]. Waitz, AB, 53. Translation from Nelson, Annals of St. Bertin, 92.

$296[\ldots]$ de omni regno suo quattuor denarios ex omni manso colligens [...]. Waitz, $A B, 67$. Translation from Nelson, Annals of St. Bertin, 112.

297 Waitz, $A B$, 81, 135; Boretius and Krause, “ECT," 354. See also Coupland, “Tribute Payments," 62-67.

298 See, for example, Hildegar, "VF," 200; Pertz, “AX," 228; Kurze, AF, 99.

$299[\ldots]$ regnum, quod contra eos redimitur, a tributo indebito eripiatur. Alfred Boretius and Victor Krause, eds., "Epistola synodi Carisiacensis ad Hludowicum regem Germaniae dicta," in MGH Capit. II (Hannover: Hahn, 1897), 431 (= ESC). Nam thesauros acclaesiarum, qui propter metum hostium absconditi fuerant, abstulit [...]. Kurze, AF, 99. Translation from Reuter, Annals of Fulda, 93. The AB names the treasury of St. Stephen in Metz as being particularly affected by the 882 levy. Waitz, $A B, 153$.

300 [...] spoliantur aeclesiae et aeclesiastica mancipia [...]. Pertz, "AV," 201. See also Coupland, "Tribute Payments," 71.

301 Waitz, $A B, 28$.

302 Ibid., 66, 91.

303 Pertz, "AFont," 301.

304 [...] Sex libras nitidi nobis causa redeundi [...]. Text and translation from Abbo, $B P U, 66-67$.

305 Waitz, AB, 33; J.F. Niermeyer and C. van de Kieft, Mediae Latinitatis lexicon minus (Leiden: Brill, 1976), 167.

$306[\ldots]$ acceptisque multis prout ipsi statuerunt [...]. Waitz, AB, 41. Translation from Nelson, Annals of St. Bertin, 74.

307 Waitz, $A B, 124$; Kurze, $A F, 80$; Pertz, “AX,” 235.

308 Williams, "Raiding and Warfare," 198.

309 Nelson, Charles the Bald, 28.

310 Coupland, "Tribute Payments," 72-75.

311 Ibid., 69. 
312 Ibid.

$313[. .$.$] multam summam argenti, frumenti quoque et vini ac animalium [...] quaesierunt,$ ut cum eis pacem facerent. Waitz, AB, 107. Translation from Nelson, Annals of St. Bertin, 164.

$314[\ldots]$ missique nuntiis praecepit habitatores loci illius tributa sibi pendere. Kurze, AF, 80. Translation from Reuter, Annals of Fulda, 72.

315 Pertz, “AV,” 200.

$316[\ldots]$ cuncta maris loca finitima diripiunt $[\ldots]$. Waitz, $A B$, 33. Translation from Nelson, Annals of St. Bertin, 61.

317 Pertz, “AV," 203.

318 In classifying these individuals, Frankish authors seem to have applied a familiar nomenclature to an unfamiliar political hierarchy, interchangeably using $d u x$, princeps, and even rex to simply signify 'leader'. For example, the second and third manuscript groups of the $A F$, in describing the Frankish siege at Asselt (882), identify the hydrarch Godfrid as $d u x$ and rex, respectively. Kurze, $A F, 98,108$. Tellingly, Abbo characterised the hydrarch Sigfrid as solo rex verbo, 'king in name only'. See Abbo, BPU, 30-31.

319 Pertz, "AV," 196, 205. These diplomats do not seem to have been invested with plenipotentiary powers.

320 [...] Ansleicus de propagine Danorum progenitus [...]. O. Holder-Egger, ed., "Miracula sancti Richarii," in MGH SS XV-II (Hannover: Hahn, 1888), 918.

321 [...] Sigefridum Danum, christianum regique fidelem [...]. Pertz, "AV," 200.

322 See also Coupland, "Poachers to Gamekeepers," 105-106.

323 Kurze, $R P, 108$; Kurze, $A F, 80$.

324 Kurze, $R P, 123$; Pertz, “AV,” 203.

$325[\ldots]$ sacramenta $[\ldots]$ statim praebuit. Waitz, $A B, 57 .[\ldots]$ iuramentis constrictus $[\ldots]$. Pertz, “AX," 235.

326 Rorik was under suspicion of having encouraged a viking fleet to move upstream along the Rhine in 863. See Ernst Perels, ed., Hincmari archiepiscopi Remensis epistolae, MGH Epp.VIII, i (Berlin: Weidmann, 1939), 120; Waitz, AB, 61. Weland was accused of breaking his oath during the same year. Ibid., 66.

$327[\ldots]$ iuramento contestatus est $[. .$.$] numquam in suum regnum hostili praedatione iturus.$ Kurze, $A F, 108$. Translation from Reuter, Annals of Fulda, 105. The 885 reference is found in Kurze, $A F, 102$.

328 Sed quia conflictus talis superare nequibat, / Militibus clamare: 'Fidem,' cepit, sed inanem, / 'Ad nostram properare, viri, nolite timere.' / Pro dolor. Alloquiis sese credunt male finctis, / [...] nudi gladium subeunt gentis truculentae, / Et caelo mittunt animas livore fluente; [...]. Text and translation from Abbo, BPU, 56-59. The notion of twelve pious martyrs has distinct apostolic connotations.

329 Adam Kosto, "Hostages in the Carolingian World (714-840)," Early Medieval Europe 11, no. 2 (2002): 128.

330 Waitz, $A B, 53,57$.

331 Ibid., 58; Pertz, “AV,” 201.

332 Adam Kosto, Hostages in the Middle Ages (Oxford: Oxford University Press, 2012), 56-57.

333 Pertz, “AV," 204.

334 Kurze, $A F, 102$.

335 Abbo, BPU, 86-87.

336 Waitz, $A B, 32$, 48; Kurze, $A F, 105$. 
337 Ibid., 99; Pertz, “AV,” 203.

338 Kurze, $A F, 80-81$.

339 Waitz, $A B, 124$; Kurze, RP, 106.

340 [...] quocumque modo possent, foedus cum eis paciscerentur [...]. Waitz, AB, 134. Translation from Nelson, Annals of St. Bertin, 198.

341 The term used is securitas (Flodoard,"AFL," 374.), which may likewise be translated as a 'promise not to take any violent action'. Niermeyer and van de Kieft, Latinitatis lexicon, 951.

342 Pippinus Danorum pyratis sociatur, Pictavorum civitatem devastat et multa alia Aquitaniae loca depopulat. Waitz, $A B, 47$. [...] se Normannis coniungit et ritum eorum servat. Ibid., 67. Translations from Nelson, Annals of St. Bertin, 84, 111.

$343[\ldots]$ auxiliorum validam manum undique contraheret et $[\ldots]$ opem ferret $[\ldots]$. Kurze, $R P$, 123. Translation from MacLean, Chronicle of Regino, 191.

344 Brett, "GSR," 215. Nortmanni commixti Brittonibus [...]. Waitz, AB, 84.

345 Nihil enim distat, utrum quis se paganis societ, an, abnegato Deo, idola adoret. Flodoard, "HRE," 565.

$346[\ldots]$ via sine impedimento attributa, ut Burgundiam hyeme depraedarent [...]. Pertz, "AV," 203.

347 Koziol, "Charles the Simple," 365n25. Regino of Prüm confirms that the decision had arisen from Burgundian disobedience. Kurze, RP, 127.

348 [...] adversus eos Danos qui in Sequana versabantur [...] eosque inde aut expulsuros aut interfecturos. Waitz, AB, 53. Translation from Nelson, Annals of St. Bertin, 92. For the 861 payment, see Waitz, $A B, 55$. Although both transactions are thought to have involved the same viking host, this cannot be stated with absolute certainty.

$349[\ldots]$ locario iure [...]. Ibid., 58.

350 Ibid., 67. [...] Nortmannorum tamen auxilia pecunia conducit [...]. Kurze, RP, 107. Translation from MacLean, Chronicle of Regino, 170.

351 See, for example, Coupland, "Vikings in Francia and Anglo-Saxon England," 197; Charles Doherty, “The Viking Impact upon Ireland," in The Vikings in Ireland, ed. Anne-Christine Larsen (Roskilde: Viking Ship Museum, 2001), 35.

$352[\ldots]$ ad patris iniuriam [...]. Waitz, AB, 26. Translation from Nelson, Annals of St. Bertin, 51.

353 Kurze, $A F, 39$.

354 [...] in fidem receptus est [...]. Ibid. Translation from Reuter, Annals of Fulda, 30.

355 Kurze, $A F$, 40; Waitz, $A B, 49$, 57, 108; Pertz, “AX,” 235.

356 Waitz, $A B, 153$; Pertz, "AV," 208. Louis III is also noted to have brought Hasting 'into his friendship' in 882 , although it is unclear whether this entailed commendation. Ibid., 199.

357 Philippe Lauer, ed., Recueil des actes de Charles III le Simple, roi de France (893-923) (Paris: Imprimerie Nationale, 1949), 211 (= C14). References to Rollo having ruled Normandy since 876 - found in $A S C(E-F)$ - draw on suspect eleventhcentury Norman histories, and are thus excluded here. See Irvine, ASC (E), lxxxviii-xc, 50; Baker, ASC (F), 1-liii, 71. Although vikings on the Loire may have commended themselves in 921, Rognvald would not be identified as a local leader for another two years. Flodoard, "AFL," 369, 372.

358 Coupland, "Poachers to Gamekeepers," 113-114. It should be emphasised that obtaining a Carolingian benefice did not automatically make the recipient a 'vassal', and that vassalage itself not necessarily entailed the granting of benefices. 


\section{Notes}

As such, the term will be avoided here. See Costambeys, Innes, and MacLean, Carolingian World, 319.

$359[. .$.$] ea condicione, ut tributus ceterisque negotiis ad regis aerarium pertinentibus fideliter$ inserviret et piraticis Danorum incursionibus obviando resisteret. Kurze, $A F, 39$. Translation from Reuter, Annals of Fulda, 30.

$360[. .$.$] finesque [...] ab incursione propriae gentis defensaret. Kurze, R P, 123$. Translation from MacLean, Chronicle of Regino, 192. [...] pro tutela regni. Lauer, Actes de Charles III, 211 (= C14).

361 Nissen-Jaubert, "Aspects of Viking Research," 163; Cooijmans, "Controlled Decline," 37.

362 Coupland, "Poachers to Gamekeepers," 113.

363 Waitz, AB, 58. [...] baptizati essent [...] et christianitatem de cetero veraciter tenere vellent [...]. Ibid., 124. Translation from Nelson, Annals of St. Bertin, 185.

$364[\ldots]$ de fonte baptismatis levavit [...]. Kurze, AF, 99. Translation from Reuter, Annals of Fulda, 93. See also Pertz, "AV," 208.

$365[\ldots]$ demonum cultoribus christiani populi deservirent! Waitz, AB, 26.

366 [...] Roricum Normannum nuper ad fidem Christi conversum [...]. Perels, Hincmari archiepiscopi Remensis epistolae, 120.

367 [...] quamvis baptizatus esset, caninam vitam digna morte finivit. Pertz, "AX," 235.

$368[. .$.$] fidem mentitus [...] et plurima loca suae dicioni subingare disposuit [...]. Kurze, A F$, 102. Translation from Reuter, Annals of Fulda, 97.

369 Pertz, "AV," 199. The $A F$ proclaim the marriage to have taken place in 883. Kurze, $A F, 100$.

370 Coupland, "Poachers to Gamekeepers," 113.

371 Smith, Province and Empire, 87.

372 Susan Reynolds, Fiefs and Vassals: The Medieval Evidence Reinterpreted (Oxford: Oxford University Press, 1994), 49, 92-93, 98-101; Halsall, Warfare and Society, 71.

373 [...] Gualacras aliaque vicina loca [...]. Waitz, AB, 26. According to the Vita Anskari, an individual named Ragnar was also granted the monastery at Torhout during the early 840s. There is no indication, however, that this transaction involved a benefice or that this Ragnar was Scandinavian. See Rimbert, VA, 46; Coupland, "Poachers to Gamekeepers," 107-108.

374 Ibid., 88.

375 Ibid., $91 \mathrm{n} 34$.

376 Kurze, $A F, 39$.

$377[\ldots]$ Dorestadum et alios comitatus largitur. Waitz, $A B, 38$.

378 [...] ex beneficio Hrorici in villa Gannita [...]. Schieffer, MGH DD Kar. III, 405 $(=C 2)$. Not to be confused with Ghent in Flanders.

379 [...] comitatus et beneficia, quae Rorich Nordmannus [...] in Kinnin tenuerat [...]. Kurze, $A F$, 99. Translation from Reuter, Annals of Fulda, 93.

380 Waitz, $A B, 39$.

381 Cooijmans, "Controlled Decline," 34-41.

382 In the early 870s, Rorik seems to have owed loyalties to both Charles the Bald and Louis the German, suggesting their recent partition of Lotharingia to have likewise divided his benefice. See Kurze, AF, 78; Waitz, AB, 121; Winroth, Age of the Vikings, 48.

383 [...] Frisiam aliosque honores quos Roricus habuerat [...]. Waitz, AB, 153. Translation from Nelson, Annals of St. Bertin, 225. Accounts of the meeting in 885 may be found in Kurze, $A F, 102,114$; Pertz, “AV,” 201; Kurze, RP, 124. 
$384[\ldots]$ terram eis ad inhabitandum delegavit. Kurze, $A F$, 40. Translation from Reuter, Annals of Fulda, 30.

385 [...] deputatam sibi hiemem exegerunt in loco qui vocatur Ghivoldi fossa [...]. Pertz, "AFont," 304.

386 Quid etiam Nortmannis per nostram commendationem [...] datum sit [...]. Alfred Boretius and Victor Krause, eds., "Capitulare missorum Suessionense," in MGH Capit. II (Hannover: Hahn, 1897), 267 (=CMS). The same passage also alludes to unspecified contributions made to vikings without this commendation.

387 Waitz, $A B, 46-47$.

388 [...] praeter partem [...] quam annuimus Normannis Sequanensibus, videlicet Rolloni suisque comitibus [...]. Lauer, Actes de Charles III, 211 (= C14). Translation from Abrams, "Early Normandy," 45n3.

389 Dudo's much-disputed account of these proceedings is found in Dudo, Normannice Ducum, 168-171.

390 [...] dono regis et principum inhabitabilem regni partem eorum, antea alligurriente uesania desolatam, sibi dispertitam incolerent. Sot, Lobrichon, and Goullet, Les Gestes des évêques d'Auxerre, I:197.

$391[\ldots]$ concessis sibi maritimis quibusdam pagis cum Rothomagensi [...] urbe et isdem subiectis. Flodoard, "HRE," 557.

392 Flodoard, "AFL," 374. [...] terram Brittonum in ora maritima sitam. Ibid., 381. Translation from Fanning and Bachrach, Annals of Flodoard, 23.

393 [...] Brittanniam [...] cum Namnetico pago concessit [...]. Flodoard, "AFL," 369. Translation from Fanning and Bachrach, Annals of Flodoard, 5.

394 Flodoard, "AFL," 377. Rognvald, a viking princeps active along the Loire, also laid waste to Neustrian lands in 924, expecting to receive possessions in the region. Ibid., 374.

395 Ibid., 384.

396 McKitterick, Frankish Kingdoms, 236-238.

397 Flodoard, “AFL,” 371.

398 Le Maho, "Fate of the Ports," 241-247; René Lepelley, “Traces des Vikings dans la toponymie actuelle de la Normandie," Annales de Normandie 52, no. 3 (2002): 199 203. Caudebec (first recorded as Caldebec) is seemingly compounded from ON kaldr ('cold') + bekkr ('stream'), and Ecquetot (Eschetot) from ON eski ('ash tree') + topt ('homestead'). See Jean Renaud, Vikings et noms de lieux de Normandie: dictionnaire des toponymes d'origine scandinave en Normandie (Cully: OREP, 2009), 41, 95.

399 Fellows-Jensen, "Place-Names and Settlement," 120-129.

400 Abrams, "Early Normandy," 54.

401 Ibid., 52; Åse Kari H. Wagner, "Les noms de lieux issus de l'implantation scandinave en Normandie: le cas des noms en -tuit," in Les fondations scandinaves en Occident et les débuts du duché de Normandie, ed. Pierre Bauduin (Caen: CRAHM, 2005), 249-250.

402 Jean Renaud, "La toponymie normanique: reflet d'une colonisation," in La progression des Vikings, des raids à la colonisation, ed. Anne-Marie Flambard Héricher (Rouen: Université de Rouen, 2003), 198-200; Ridel, "From Scotland to Normandy," 81-84.

403 Thibault Cardon et al., "Le premier trésor monétaire de type viking en France. Denier inédit d'Eudes pour Beauvais," Revue numismatique 6, no. 164 (2008): 2129; Le Maho, "La Seine et les Normands," 30.

404 François de Beaurepaire, "La diffusion de la toponymie scandinave dans la Normandie ducale," Tabularia "Etudes" 2 (2002): 49. 
405 See likewise Section I.3, as well as Roesdahl, "What May We Expect?," 207-208.

406 David Bates, Normandy before 1066 (Harlow: Longman, 1982), 20-21.

407 [...] fuerint baptizati \& rebaptizati, \& post baptismum gentiliter vixerint, atque Paganorum more Christianos interfecerint, sacerdotes trucidaverint, atque simulacris immolantes [...]. Philippe Labbé and Gabriel Cossart, eds., "Vita et epistolae Ioannis papae IX," in Sacrosancta concilia ad regiam editionem exacta, vol. IX (Paris: Societas Typographica Librorum Ecclesiasticorum, 1671), col. 483. Hervé's letter to Wito compares this relapse into paganism to 'pigs returning to their wallowing-place, and dogs to their vomit' (sues suum reversi ad volutabrum, \& canes ad vomitum). Ibid., col. 484. See also Christine Walsh, "Baptized but not Converted: The Vikings in Tenth-Century Francia," Studies in Church History 51 (2015): 73.

408 Bates, Normandy before 1066, 21-23.

409 [...] paganis illis, qui in eadem civitate habitant [...]. Hincmar, "Epistolae," in PL CXXVI, ed. Jacques-Paul Migne (Montrouge: Migne, 1852), col. 225. See also Price, The Vikings in Brittany, 51.

$410[\ldots]$ suisque hominibus ad inhabitandum [...]. Kurze, AF, 99.

411 Waitz, $A B, 46$; Kurze, $A F, 47$.

412 Van Es, "Dorestad Centred," 162.

413 W.A. van Es and W.J.H. Verwers, Excavations at Dorestad III: Hoogstraat 0, II-IV (Amersfoort: RACM, 2009), 36-38, 244-247; Annemarieke Willemsen, "Dorestad as a Fluviatile Society," in Maritime Societies of the Viking and Medieval World, ed. James H. Barrett and Sarah Jane Gibbon (Leeds: Maney, 2016), 116-118; Karel Vlierman, "Scheeps- en stadsarcheologie: de betekenis van scheeps(hout)vondsten in Nederlandse middeleeuwse steden," in Middeleeuwse toestanden: archeologie, geschiedenis en monumentenzorg, ed. P.J. Woltering, W.J.H. Verwers, and G.H. Scheepstra (Hilversum: Verloren, 2002), 135, 141.

414 Ibid., 141. Fragments of another Scandinavian-type clinker-built ship - presumably constructed around London during the late tenth or early eleventh century have likewise been uncovered in Tiel. Juke Dijkstra et al., Archeologisch onderzoek in de binnenstad van Tiel - juni t/m september 1996: Lokaties Koornmarkt en Tol-Zuid (Amersfoort: ROB, 1998), 45-47, 56-58.

415 Pilø, "Pottery," 291, 302; Janssen, Importkeramik, 70-73.

416 Heiko Steuer, "Der Handel der Wikingerzeit zwischen Nord- und Westeuropa aufgrund archäologischer Zeugnisse," in Untersuchungen zu Handel und Verkehr der vor- und frühgeschichtlichen Zeit in Mittel- und Nordeuropa, ed. Klaus Düwel (Göttingen: Vandenhoeck \& Ruprecht, 1987), 134.

417 Bjarne Gaut, "Vessel Glass from Kaupang: A Contextual and Social Analysis," Norwegian Archaeological Review 40, no. 1 (2007): 29-36; Steuer, "Handel Der Wikingerzeit," 146, 158; Neeke Fraenkel-Schoorl, "Carolingian Jewellery with Plant Ornament," Berichten van de Rijksdienst voor het Oudheidkundig Bodemonderzoek 28 (1978): 345-391.

418 Dagfinn Skre, "The Inhabitants: Origins and Trading Connexions," in Things from the Town: Artefacts and Inhabitants in Viking-Age Kaupang, ed. Dagfinn Skre (Aarhus: Aarhus University Press, 2011), 426; Feveile, Viking Ribe, 35.

419 Ahmad ibn Fadlan, Mission to the Volga, trans. J. Montgomery (New York: NYU Press, 2017), 32.

420 In Scandinavia alone, over five dozen Ulfberht-swords have been identified. See Stalsberg,"Vlfberht-Schwertklingen," 91-95. Counterfeit swords of varying quality likewise seem to have circulated. See Alan Williams, The Sword and the Crucible: A 
History of the Metallurgy of European Swords up to the 16th Century (Leiden: Brill, 2012), 122.

421 McCormick, European Economy, 732.

422 Jan Besteman, "Scandinavisch gewichtsgeld in Nederland in de Vikingperiode," in Van Solidus tot Euro: Geld in Nederland in economisch-historisch en politiek perspectief, ed. E.H.P. Cordfunke and Herbert Sarfatij (Hilversum: Verloren, 2004), 30-34; McCormick, European Economy, 821.

423 Jean Soulat, "Le port de Taillebourg - Port d'Envaux et les contacts avec le Nord-Ouest de l'Europe," in Archéologie et histoire du fleuve Charente: TaillebourgPort d'Envaux, ed. Annie Dumont and Jean-François Mariotti (Dijon: Éditions Universitaires, 2013), 254-256.

$424[. .$.$] speciem praeferens multitudinis negotium exercentis. Bruno Krusch, ed., "Miracula$ Martini abbatis Vertavensis," in MGH SRM III (Hannover: Hahn, 1896), 573.

$425[\ldots]$ negotiatores [...] mercimonia deferentes emerent et venderent [...]. Kurze, AF, 78.

426 See, for example, Verhulst, Carolingian Economy, 134-135. The emporium of Quentovic, however, seems to have survived and thrived well into the tenth century. Coupland, "Trading Places: Quentovic and Dorestad Reassessed," 227.

427 Cooijmans, "Controlled Decline," 38-40;Verhulst, Carolingian Economy, 134.

428 Costambeys, Innes, and MacLean, Carolingian World, 351.

429 Waitz, $A B, 81$.

430 [...] Nortmannis sibi notis [...]. Pertz, “AV," 204.

431 D.M. Metcalf, "Viking-Age Numismatics 2: Coinage in the Northern Lands in Merovingian and Carolingian Times," Numismatic Chronicle 156 (1996): 422-423; Nelson, "Frankish Empire," 37.

432 Nelson, Charles the Bald, 33.

1 Despite occurring in the same sequence, the rate at which these events unfolded seems to have differed between respective Frankish regions. As such, demarcating the individual phases of the conceptual model by exact years - rather than a more approximate timeline - would be a counterproductive exercise.

2 Verhulst, Carolingian Economy, 122-123.

3 A.A.A. Verhoeven, "Verspreidingsgebieden van aardewerk in de vroege en volle middeleeuwen," in Rotterdam Papers, ed. A. Carmiggelt, vol. 7 (Rotterdam: ROB, 1992), 77-80; Verhulst, Rise of Cities, 50-51;Verhulst, "Economic Organisation," 500-501, 508. See also Sections III.2.1 and III.2.2.

4 Päffgen, "Urban Settlements," 91; Verhulst, Rise of Cities, 47-48, 54-56.

5 A map of principal ninth-century monasteries across Francia is found in McKitterick, Frankish Kingdoms, 377. For regional royal residences, see, for example, Karl Bosl, "Pfalzen und Forsten," in Deutsche Königspfalzen, ed. Hermann Heimpel, vol. I (Göttingen: Vandenhoeck \& Ruprecht, 1963), 20.

6 McKitterick, Frankish Kingdoms, 372-373.

7 Sindbæk, "Emergence of Towns," 121-124. See Section IV.1 for further details.

8 Näsman,"Exchange and Politics," 40-41;Ljungkvist,"Continental Imports," 37-39.

9 Claus Feveile, "Mayen Lava Quern Stones from the Ribe Excavations 1970-76," in Ribe Excavations 1970-76, ed. Mogens Bencard and Helge Brinch Madsen, vol. 6 (Aarhus: Jutland Archaeological Society, 2010), 142-145.

10 Lebecq, "Long Distance Merchants," 235-236.

11 RudolfSimek, "The Emergence of theViking Age: Reasons and Triggers," in Vikings on the Rhine: Recent Research on Early Medieval Relations between the Rhinelands and Scandinavia, ed. Rudolf Simek and Ulrike Engel (Vienna: Fassbaender, 2004), 13. 
12 As noted in Section V.1.2, a prior attack on Frisia, dated to 810, is thought to have been monarchic (rather than hydrarchic) in character.

$13[\ldots]$ ceperunt $[\ldots]$ praedam magnam. Pertz, "CM," 311.

14 Kurze, $A R F$, 153; Waitz, $A B$, 9-13; Kurze, $A F$, 27-28; Pertz, “AX,” 226. See also Section V.1.2.

15 For a discussion on these particular land grants, see Section V.1.3.

16 See, for example, Kurze, $A R F$, 110; Waitz, $A B, 13$; Kurze, $A F$, 27; Einhard, $V K M, 21$, as well as Sections V.1.3 and V.3.

17 Waitz, $A B, 41$; Pertz, “AX,” 230-231; Kurze, AF, 96; Kurze, RP, 118.

18 Waitz, $A B$, 153; Kurze, $A F$, 96-97; Pertz, “AV,” 199; Kurze, RP, 118.

19 Coastal incursions on Frisia are recorded in Waitz, $A B, 41-42$; Pertz, "AX," 228229, 233. For the various Dorestad attacks, see Waitz, $A B$, 35, 48, 61; Kurze, $A F$, 36, 39; Pertz, "AX," 228-229.

20 [...] habitaverunt ad tempus [...]. Ibid., 231. See also Waitz, $A B, 61$; Kurze, $A F$, 96; Kurze, $R P, 122$.

21 See, for example, Pertz, “AV,” 197-199, 201, 205. See also Table VI.3.

22 Besteman, "Viking Silver on Wieringen," 253-265; Besteman, "Wieringen: Westerklief II," 65-73. See also Section VI.2.1.2.

23 Waitz, AB, 33, 124; Kurze, AF, 35, 80, 86; Pertz, “AX,” 228, 235; Pertz, “AV," 203. The two hydrarchs in question were Rodulf ( $†$ 873) and Sigfrid ( $†$ 887).

24 See, for example, Kurze, AF, 94, 98, 101-102, 119-120; Pertz, “AV,” 198-199, 201.

25 See Section VI.3.1.2, esp. Table VI.4

26 Waitz, $A B, 33,41$. [...] plura milia argenti et auri [...]. Ibid., 153. For more details, see Section VI.3.3.1, esp. Table VI.5.

27 Waitz, $A B, 26$.

28 [...] Dorestado se continent [...]. Ibid., 46. See also Section VI.4.2.1.

29 See Sections VI.4.2.1 and VI.4.2.2.

30 Skre, "Inhabitants," 426-427; Unn Pedersen, "Urban Craftspeople at Viking-Age Kaupang," in Everyday Products in the Middle Ages: Crafts, Consumption and the Individual in Northern Europe c. AD 800-1600, ed. Gitte Hansen, Steven Ashby, and Irene Baug (Oxford: Oxbow, 2015), 59-60; Claus Feveile and Stig Jensen, "Ribe in the 8th and 9th Century: A Contribution to the Archaeological Chronology of North Western Europe," Acta Archaeologica 71 (2000): 13.

31 Stalsberg, "Vlfberht-Schwertklingen," 89-97. See also Section VI.5.

32 Egon Wamers, "Continental and Insular Metalwork," in Things from the Town: Artefacts and Inhabitants in Viking-Age Kaupang, ed. Dagfinn Skre (Aarhus: Aarhus University Press, 2011), 72, 90-92; Skre, "Inhabitants," 411-412, 433-434.

33 Van Es and Verwers, Excavations at Dorestad IV,318. The local distribution of amber fragments suggests their import to have continued well into the second half of the ninth century.

34 A brief consideration of these latter-day campaigns may be found in Jesch, Ships and Men, 82.

35 [...] Godefridus moritur omnesque Nortmanni, qui in Batua reperti sunt, trucidantur. Kurze, RP, 124. Translation from MacLean, Chronicle of Regino, 193.

36 For regional cereal and wine production, see, for example, Konrad Elmshäuser and Andreas Hedwig, Studien zum Polyptychon von Saint-Germain-des-Prés (Cologne: Böhlau, 1993), 339-399.

37 McCormick, European Economy, 702; Isabelle Daveau and Vincent Goustard, "Un complexe métallurgique et minier du Haut Moyen Age: le site des fourneaux à 
Vert-Saint-Denis (Seine-et-Marne)," Gallia 57 (2000): 80-83; Elmshäuser and Hedwig, Studien zum Polyptychon von Saint-Germain-des-Prés, 196-201; Verhulst, Carolingian Economy, 77-79.

38 See, for example, Richard Hodges, "The 8th-Century Pottery Industry at La Londe, near Rouen, and its Implications for Cross-Channel Trade with Hamwic, AngloSaxon Southampton," Antiquity 65 (1991): 883-886; Pierre Riché, Daily Life in the World of Charlemagne (Liverpool: Liverpool University Press, 1973), 160-161.

39 Verhulst, Carolingian Economy, 60, 101-102.

40 McCormick, European Economy, 644, 647-652.

41 Within the boundaries of this case study, Noyon, Laon, Soissons, Beauvais, Senlis, and Châlons adhered to the province of Rheims, whilst Évreux and Lisieux were suffragan to Rouen, and Paris, Meaux, Troyes, Auxerre, and Chartres were presided over by Sens. See McKitterick, Frankish Kingdoms, 372-373.

42 Stuart Airlie, "The Palace of Memory: The Carolingian Court as Political Centre," in Courts and Regions in Medieval Europe, ed. Sarah Rees Jones, Richard Marks, and A.J. Minnis (York: York Medieval Press, 2000), 14; Loveluck, Northwest Europe, 114-119.

43 Mühlbacher, MGH DD Kar. I, 9.

44 Steuer, "Handel der Wikingerzeit," 125.

45 Édouard Salin, "Les tombes gallo-romaines et mérovingiennes de la basilique de Saint-Denis (Fouilles de Janvier-Février 1957)," Mémoires de l'institut national de France 44, no. 1 (1960): 226, 250, 261; J.B.D. Cochet, "Une fouille en Normandie ou notice sur des sépultures chrétiennes: trouvées en mars 1871, a Saint-Ouen de Rouen," Revue archéologique 25 (1873): 89-92; J.-M. Desbordes, "Informations archéologiques: circonscription de Picardie," Gallia 33, no. 2 (1975): 303.

46 Pilø, "Pottery," 294-295. See also note 38.

47 Bjarne Gaut,"Vessel Glass and Evidence of Glassworking," in Things from the Town: Artefacts and Inhabitants in Viking-Age Kaupang, ed. Dagfinn Skre (Aarhus: Aarhus University Press, 2011), 189, 249;Vera Evison, "Le verre carolingien," in À travers le verre: du Moyen Age à la Renaissance, ed. Danièle Foy and Geneviève Sennequier (Rouen: Musées et Monuments departémentaux de la Seine-Maritime, 1989), 140, 145.

48 Einhard, VKM, 21. Clare Downham's recent reconsideration of early textual evidence from southern England suggests its coasts to have been subject to similar viking antagonism at this same time. See Downham, "Earliest Viking Activity."

49 In ostia Sequanae [...] temptantes resistentibus sibi litoris custodibus, quinque suorum interfectis inritae recesserunt. Kurze, ARF, 153-154. Translation from Scholz, Carolingian Chronicles, 108.

50 These defensive measures are discussed in Section V.3.

51 Disposuit et marchas suas undique, nam et praesidia posuit in litore maris, ubi necesse fuit; [...]. Pertz, "CM," 311.

$52[\ldots]$ contra paganos expeditione $[m]$ atq $[u e]$ arcis munitione $[m]$ distructionemue. John Earle, ed., A Hand-Book to the Land-Charters, and Other Saxonic Documents (Oxford: Clarendon, 1888), 88. Translation from Downham, "Earliest Viking Activity," 8. See also Frank Stenton, Anglo-Saxon England, 3rd ed. (Oxford: Oxford University Press, 1971), 292.

53 Waitz, $A B$, 25; Pertz, "AFont," 301. Whether watchmen were still stationed along the river mouth at this time is unclear.

54 Waitz, $A B, 32$; Kurze, $A F, 35$; Pertz, “AFont," 302; “TSG,” 80.

55 Waitz, $A B$, 52, 57; Pertz, “AV,” 203; Kurze, RP, 133; Flodoard, “AFL,” 375. 
56 Waitz, AB, 49, 80; Pertz, “AFont,” 303; “TSG,” 80-81; Abbo, BPU, 52, 66.

$57[\ldots]$ cuncta maris loca finitima diripiunt [...]. Waitz, $A B$, 33. Translation from Nelson, Annals of St. Bertin, 61.

$58[\ldots]$ stationique munitissimum [...]. Waitz, $A B$, 47. See also Section VI.2.2.1, esp. note 211 .

59 Waitz, AB, 57, 81; Pertz, “AV,” 203, 208-209; Pertz, “AFont,” 304; Kurze, RP, 130131; Bately, $A S C(A), 53$. See also Table VI.3.

60 See, for example, Waitz, $A B, 50$; Pertz, “AV,” 204. The fortified bridges are discussed in Section VI.3.1.2.

61 Boretius and Krause, "CC," 360; P. Kehr, ed., Karoli III. diplomata (Berlin: Weidmann, 1937), 245-246 (= C3); Waitz, AB, 52; “TSG,” 75. See also Sections VI.3.1.2 and VI.3.2.1.

62 These tributes are discussed in Section VI.3.3.1.

$63[\ldots]$ in societatem regni suscepit [...]. Kurze, AF, 40. Translation from Reuter, Annals of Fulda, 30 .

64 Waitz, $A B, 49 .[\ldots]$ se commendavit [...]. Ibid., 57.

65 See Section VI.4.2.1, as well as Le Maho, "Fate of the Ports," 244-247.

66 [...] ad Rothomo porto et Wicus porto, qui veniunt de ultra mare pro vina et melle vel garantia emendum; [...].Georg Heinrich Pertz, ed., MGH Diplomatum Imperii I (Hannover: Hahn, 1872), 140-141. A brief discussion on the merits of the document may be found in Stéphane Lebecq, Marchands et navigateurs frisons du haut Moyen Age, vol. II (Lille: Presses Universitaires de Lille, 1983), 400-401, 404.

67 Wamers, "Continental and Insular Metalwork," 77-79, 90-92. Whilst being typologically dated to c. 750-900, the items are stratigraphically associated with a local merchant's house of Frankish or Frisian character, which remained in use until the mid-ninth century. See Skre, "Inhabitants," 431.

68 Waitz, $A B, 81$. See also Section VI.5.

69 The death of William, Rollo's son, caused regional viking activity to briefly flare up during the early 940s. Sawyer, Kings and Vikings, 92.

70 Bates, Normandy before 1066, 6-7; Fellows-Jensen, "Place-Names and Settlement," 133-134. See also Section VI.4.2.2.

71 See, for example, Bates, Normandy before 1066, 242-248. The political relationship between the early Norman rulers and the Frankish kings is discussed in Mark Hagger, Norman Rule in Normandy: 911-1144 (Woodbridge: Boydell, 2017), 250-265.

72 Verhulst, Carolingian Economy, 80-81, 113.

73 Bruand, "Sel de l'Atlantique," 17-20; McCormick, European Economy, 646.

74 Verhulst, Carolingian Economy, 81, 94; François-Louis Ganshof, “À propos du tonlieu à l'époque carolingienne," in La città nell'alto medioevo, ed. Centro italiano di studi sull'alto medioevo (Spoleto: Presso la Sede del Centro, 1959), 487-489.

75 Loveluck, Northwest Europe, 168; McCormick, European Economy, 643-644;Verhulst, Carolingian Economy, 81.

76 McKitterick, Frankish Kingdoms, 372-373. The case study also encompasses parts of the ecclesiastical provinces of Bordeaux and Lyons.

77 Ibid., 377.

78 Ermentar, "Vita sancti Filiberti," in Monuments de l'histoire des abbayes de SaintPhilibert, ed. René Poupardin (Paris: Picard, 1905), 17; Bruno Krusch, ed., "Vita Columbani abbatis discipulorumque eius," in MGH SRM IV (Hannover: Hahn, 1902), 205-206. See also Bruand, "Sel de l'Atlantique," 18. 
79 Bendixen, "Sceattas and Other Coin Finds," 73-74.

80 Soulat, "Port de Taillebourg," 255-256; Annie Dumont, Jean-François Mariotti, and Jean Soulat, "Taillebourg, une base viking sur la Charente? Le témoignage de l'archéologie," in Les Vikings dans l'empire franc, ed. Élisabeth Ridel (Bayeux: OREP, 2014), 44-48.

81 Bouquet, "Diplomata Ludovici," 516-517.

82 Kurze, $A R F, 154$; Bouquet, "Diplomata Ludovici," 564.

83 Astronomus, "Vita Hludowici," 324; Ermentar, "MSF," 25; Bouquet, "Diplomata Ludovici," 564. See also Section V.3.

84 Pertz, "AEng," 485.

85 Ermentar, “MSF," 23, 59. See also Cédric Jeanneau, "Les moines de Saint-Philibert de Noirmoutier et les invasions scandinaves," in Landévennec: les Vikings et la Bretagne, ed. Magali Coumert and Yvon Tranvouez (Brest: Université de Bretagne Occidentale, 2015), 114-116.

86 See, for example, Waitz, AB, 29; Pertz, “AEng," 486; Pertz, “AFont," 302. See also Section VI.1.3, esp. note 112 .

87 See, for example, Waitz, $A B, 42-43,45-46,67,75,80$.

88 Dani Aquitaniae maritima inpetunt et praedantur [...]. Ibid., 35. Translation from Nelson, Annals of St. Bertin, 65.

89 Brett, "GSR," 215; Adrevald, "MSB," 494. See also Section VI.2.2, esp. Table VI.3.

$90[\ldots]$ diuturno tempore residebant [...]. Waitz, $A B, 123$.

91 Ibid., 46, 84, 97, 107.

92 References to the fortifications may be found in Table VI.4.

93 Boretius and Krause, "CC," 361. See also Section VI.3.1.2.

94 Waitz, AB, 43; Kurze, RP, 106; DeSelm, "Unwilling Pilgrimage," 269-288. For a list of regional tribute payments, see Table VI.5.

95 Brett, “GSR," 215; Waitz, $A B, 84$.

96 Ibid., 47. See also Nelson, Charles the Bald, 173.

97 Pertz, “AV," 199. For further references to Hasting, see Table VI.6.

98 Flodoard, “AFL," 369. See also Section VI.4.2.1.

99 Flodoard, “AFL," 377.

100 These objects, thought to have been used for the smoothing of textiles, have likewise been found on the British-Irish Isles and in Novgorod. See Gaut, "Vessel Glass," 230-231; Peter Steppuhn, Die Glasfunde von Haithabu (Neumünster: Wachholtz, 1998), 74-76. The evidence from Scandinavia has been dated stratigrafically.

101 Bernard Gratuze et al., "Les 'lissoirs' carolingiens en verre au plomb: mise en évidence de la valorisation des scories issues du traitement des galènes argentiferes de Melle (Deux-Sèvres)," in Echanges et commerce du verre dans le monde antique, ed. Danièle Foy and Marie-Dominique Nenna (Drémil-Lafage: Mergoil, 2003), 103105; Gaut, "Vessel Glass," 230.

102 Florian Tereygeol, "Production and Circulation of Silver and Secondary Products (Lead and Glass) from Frankish Royal Silver Mines at Melle (Eighth to Tenth Century)," in Post-Roman Towns, Trade and Settlement in Europe and Byzantium: The Heirs of the Roman West, ed. Joachim Henning (Berlin: de Gruyter, 2007), 133.

103 Zuyderwijk 84-86, 135; Loveluck, Northwest Europe, 203.

104 Jean Duplessy, Les trésors monétaires médiévaux et modernes découverts en France, vol. I (Paris: Bibliothèque nationale, 1985), 112; Loveluck, Northwest Europe, 194; Lewis, "Salt and the Earliest Scandinavian Raids," 121-122. 
70 Notes

105 Flodoard, "AFL," 384. Although considered mostly unreliable, the eleventhcentury Chronicon Namnetense states that a force led by Alan II drove all vikings from Brittany and the River Loire in 937. See Merlet, CN, 87-88.

106 See Table VI.3 and Figure VI.6 for a list and map of recorded Scandinavian encampments (840-940).

107 See Section VI.2.1.2 for a more extensive consideration of local encampment.

108 The institution of commendation is discussed in further detail in Section VI.4.2.

1 Hic populi porro veteri cognomine Deni / Ante vocabantur et vocitantur adhuc; / Nortquoque Francisco dicuntur nomine - manni, / Veloces, agiles, armigerique nimis. / Ipse quidem populus late pernotus habetur, / Lintre dapes quaerit, incolitatque mare; [...]. Ermold, "In honorem Hludowici Caesaris Augusti libri IIII," in MGH SS II, ed. Georg Heinrich Pertz (Hannover: Hahn, 1829), 501.

2 Examples of such hydrarchic dissonance are provided in Section VI.1.1.1.

3 The organisational pliancy of hydrarchic hosts is discussed in Sections II.1.3 and VI.1.1.1.

4 This complementary balance between commerce and coercion is discussed in Sections VI.2.1.3 and VI.5. 


\section{Bibliography}

\section{Archival sources}

Angers Miscellany. MS 817 (733). Municipal Library, Angers, France.

Calendarium. MS Thott $2392^{\circ}$. Royal Library, Copenhagen, Denmark.

Institutio et Regula canonicorum in concilio Aquisgranensi (816) editae. MS 789 (G. 599).

Municipal Library, Rheims, France.

Tours Miscellany. MS 106. Municipal Library, Tours, France

\section{Charter evidence}

C1 - Charter of the abbey of Redon (8 July 857).

Courson, Cartulaire de l'abbaye de Redon en Bretagne, 21-22.

C2 - Diploma of King Lothar II to the abbey of Lorsch (13 September 860).

Schieffer, MGH DD Kar. III, 404-405.

C3 - Diploma of King Charles the Fat to Bishop Geilo of Langres (15 January 887).

Kehr, MGH Karoli III. diplomata, 244-246.

C4 - Diploma of King Odo to the abbey of Vézelay (10 July 889).

Bautier, Recueil des actes d'Eudes, 41-45.

C5 - Diploma of King Odo to the abbey of St. Philibert, Tournus (16 July 889).

Bautier, Recueil des actes d'Eudes, 63-65.

C6 - Diploma of King Odo to the abbey of St.Vaast, Arras (21 May 890).

Bautier, Recueil des actes d'Eudes, 85-98.

C7 - Diploma of King Charles the Simple to Bishop Heidilo of Tournai (n.d.)

Lauer, Recueil des actes de Charles III le Simple, 1-4.

C8 - Diploma of King Charles the Simple to the abbey of St. Denis (8 February 898). Lauer, Recueil des actes de Charles III le Simple, 15-17.

C9 - Diploma of King Charles the Simple to Fleury Abbey, St. Benoît-sur-Loire (30 October 900).

Lauer, Recueil des actes de Charles III le Simple, 71-74.

C10 - Diploma of King Charles the Simple to the abbey of Corbie (9 November 901). Lauer, Recueil des actes de Charles III le Simple, 87-90.

C11 - Bull of Pope Christopher to the abbey of Corbie (26 December 903).

Migne, PL CXXXI, cols. 45-48.

C12 - Diploma of King Charles the Simple to Bishop Stephen of Cambrai (20 December 911).

Lauer, Recueil des actes de Charles III le Simple, 150-152. 
C13 - Diploma of King Charles the Simple to the abbey of St. Cornelius, Compiègne (26 July 917). Lauer, Recueil des actes de Charles III le Simple, 202-206.

C14 - Diploma of King Charles the Simple to the abbey of St. Germain-des-Prés (14 March 918).

Lauer, Recueil des actes de Charles III le Simple, 209-212.

C15 - Diploma of King Charles the Simple to the abbey of St. Martin, Tours (1 December 918).

Lauer, Recueil des actes de Charles III le Simple, 225-227.

C16 - Diploma of King Charles the Simple to the abbey of St. Martin, Tours (27 June 919).

Lauer, Recueil des actes de Charles III le Simple, 231-240.

C17 - Charter of the abbey of St. Maximin, Trier (926).

Martène and Durand, Veterum scriptorum, I: cols. 280-281.

C18 - Charter of the abbey of St. Maximin, Trier (926).

Martène and Durand, Veterum scriptorum, I: col. 282.

C19 - Diploma of King Rudolf to the abbey of St. Martin, Tours (24 March 931).

Dufour, Recueil des actes de Robert I ${ }^{\text {er }}$ et de Raoul, 60-70.

C20 - Diploma of King Louis IV to the abbey of Vézelay (26 July 936).

Lauer, Recueil des actes de Louis IV,3-5.

C21 - Diploma of King Louis IV to the abbey of St. Martin, Tours (28 October 938). Lauer, Recueil des actes de Louis IV, 25-29.

C22 - Diploma of King Louis IV to the abbey of St. Remi, Rheims (940). Lauer, Recueil des actes de Louis IV, 38.

C23 - Diploma of King Louis IV to the abbey of St. Hilary, Poitiers (5 January 942). Lauer, Recueil des actes de Louis IV, 45-47.

C24 - Diploma of King Otto I to the episcopal church of Cambrai (13 June 958).

Societas Aperiendis Fontibus, MGH Diplomatum regum et imperatorum Germaniae, I: $275-276$.

\section{Other primary sources}

Abbo. Viking Attacks on Paris: The Bella Parisiacae Urbis of Abbo of Saint-Germain-des-Prés. Edited by Nirmal Dass. Paris: Peeters, 2007.

Adalelm. "Epistola Adelermi." Edited by Ferdinand Lot. Revue belge de philologie et d'histoire 18, nos. 2-3 (1939): 503-504.

Adam. "Gesta Hammenburgensis ecclesiae pontificum." In MGH SS VII, edited by Georg Heinrich Pertz, 267-389. Hannover: Hahn, 1846.

Ado. "Ex Adonis archiepiscopi Viennensis chronico." In MGH SS II, edited by Georg Heinrich Pertz, 315-326. Hannover: Hahn, 1829.

Adrevald. "Miraculis sancti Benedicti." In MGH SS XV-I, edited by O. Holder-Egger, 474-497. Hannover: Hahn, 1887.

Aimoin. "De miraculis sancti Germani." In PL CXXVI, edited by Jacques-Paul Migne, cols. 1027-1056. Montrouge: Migne, 1852.

Alcuin. "Epistolae." In MGH Epp. IV, edited by Ernst Dümmler, 1-493. Berlin: Weidmann, 1895.

—. "Vita Willibrordi archiepiscopi Traiectensis." In MGH SRM VII, edited by Bruno Krusch and W. Levison, 81-141. Hannover: Hahn, 1920.

Allott, Stephen, trans. Alcuin of York: His Life and Letters.York: Ebor Press, 1974. 
Altfrid. "Vita sancti Liudgeri.” In MGH SS II, edited by Georg Heinrich Pertz, 403-425. Hannover: Hahn, 1888.

Asser. "Ex Asserii Gestis Aelfredi." In MGH SS XIII, edited by R. Pauli, 120-122. Hannover: Hahn, 1881.

Astronomus. "Vita Hludowici imperatoris." In MGH SRG LXIV, edited by Ernst Tremp, 279-555. Hannover: Hahn, 1995.

Audrad. "Die Fragmente des Liber revelationum." In O Roma nobilis: Philologische Untersuchungen aus dem Mittelalter, edited by Ludwig Traube, 82-93. Munich: Königliche Akademie, 1891.

Baker, Peter S., ed. The Anglo-Saxon Chronicle: A Collaborative Edition - MS F. Cambridge: Brewer, 2000.

Bately, Janet, ed. The Anglo-Saxon Chronicle: A Collaborative Edition - MS A. Cambridge: Brewer, 1986. , ed. The Old English Orosius. Oxford: Oxford University Press, 1980.

Bautier, M. Robert-Henri, ed. Recueil des actes d'Eudes, roi de France (888-898). Paris: Imprimerie Nationale, 1967.

Bede. Ecclesiastical History of the English People. Edited by Bertram Colgrave and R. Mynors. Oxford: Clarendon, 1969.

Bischoff, Bernhard, ed. Mittelalterliche Schatzverzeichnisse.Vol. I. Munich: Prestel, 1967.

Boretius, Alfred, ed. "Capitula cum primis conferenda." In MGH Capit. I, 138-139. Hannover: Hahn, 1883.

— , ed. "Capitula missorum Hludovici." In MGH Capit. I, 300-301. Hannover: Hahn, 1883.

— ed. "Capitulare Bononiense.” In MGH Capit. I, 166-167. Hannover: Hahn, 1883.

— ed. “Capitulare Haristallense.” In MGH Capit. I, 46-51. Hannover: Hahn, 1883. ,ed.“Capitulare Mantuanum.” In MGH Capit. I,190-191.Hannover: Hahn, 1883.

—_ ed. “Capitulare missorum.” In MGH Capit. I, 114-116. Hannover: Hahn, 1883. , ed. "Capitulare missorum in Theodonis villa datum secundum." In MGH Capit. I, 122-126. Hannover: Hahn, 1883.

— ed. "Capitularia missorum specialia." In MGH Capit. I, 99-102. Hannover: Hahn, 1883.

Boretius, Alfred, andVictor Krause, eds. “Capitula Pistensia.” In MGH Capit. II, 302-310. Hannover: Hahn, 1897. 1897. , eds. "Capitulare Carisiacense." In MGH Capit. II, 355-361. Hannover: Hahn,

— , eds. “Capitulare missorum Silvacense.” In MGH Capit. II, 270-276. Hannover: Hahn, 1897.

—, eds. "Capitulare missorum Suessionense." In MGH Capit. II, 266-270. Hannover: Hahn, 1897.

— eds. "Edictum Compendiense de tributo Nordmannico." In MGH Capit. II, 353-354. Hannover: Hahn, 1897.

— eds. “Edictum Pistense.” In MGH Capit. II, 310-328. Hannover: Hahn, 1897. , eds. "Epistola synodi Carisiacensis ad Hludowicum regem Germaniae directa." In MGH Capit. II, 427-441. Hannover: Hahn, 1897.

— eds. "Hlotharii, Hludowici et Karoli conventus apud Marsnam primus." In MGH Capit. II, 68-71. Hannover: Hahn, 1897.

- eds. "Libellus proclamationis adversus Wenilonem.” In MGH Capit. II, 450-453.

Hannover: Hahn, 1897. 


\section{Bibliography}

Bouquet, Martin, ed. "Diplomata Ludovici Pii imperatoris." In Recueil des historiens des Gaules et de la France, VI:455-632. Paris: Libraires associés, 1749.

Braithwaite, Richard. Whimzies: or, a New Cast of Characters.London: Felix Kingston, 1631. Brett, Caroline, ed. “Gesta sanctorum Rotonensium.” In The Monks of Redon, 103-219. Woodbridge: Boydell, 1989.

Christiansen, Eric, trans. History of the Normans. Woodbridge: Boydell, 1998.

Cubbin, G.P., ed. The Anglo-Saxon Chronicle: A Collaborative Edition - MS D. Cambridge: Brewer, 1996.

de Courson, Aurélien, ed. Cartulaire de l'abbaye de Redon en Bretagne. Paris: Imprimerie Impériale, 1863.

Dudo. De moribus et actis primorum Normannice ducum. Caen: Blanc-Hardel, 1865.

Dufour, Jean, ed. Recueil des actes de Robert I ${ }^{e r}$ et de Raoul, rois de France (922-936). Paris: Imprimerie Nationale, 1978.

Dümmler, Ernst, ed. "Pauli et Petri diaconorum carmina." In MGH Poetae I, 27-86. Berlin: Weidmann, 1881.

Earle, John, ed. A Hand-Book to the Land-Charters, and Other Saxonic Documents. Oxford: Clarendon, 1888.

Einhard. "Translatio et miracula sanctorum Marcellini et Petri." In MGH SS XV-I, edited by G. Waitz, 238-264. Hannover: Hahn, 1887.

—. Vita Karoli magni. Edited by G. Waitz. MGH SRG XXV. Hannover: Hahn, 1911.

Erhard, Heinrich, ed. Regesta historiae Westfaliae accedit codex diplomaticus.Vol. I. Münster: Regensberg, 1847.

Ermentar. "De translationibus et miraculis sancti Filiberti." In Monuments de l'histoire des abbayes de Saint-Philibert, edited by René Poupardin, 19-70. Paris: Picard, 1905.

_ . "Vita sancti Filiberti." In Monuments de l'histoire des abbayes de Saint-Philibert, edited by René Poupardin, 3-18. Paris: Picard, 1905.

Ermold. "In honorem Hludowici Caesaris Augusti libri IIII." In MGH SS II, edited by Georg Heinrich Pertz, 466-516. Hannover: Hahn, 1829.

Fanning, Steven, and Bernard S. Bachrach, trans. The Annals of Flodoard of Reims. Peterborough, ON: Broadview Press, 2004.

Flodoard. "Annales." In MGH SS III, edited by Georg Heinrich Pertz, 363-408. Hannover: Hahn, 1839.

- "Historia Remensis ecclesiae." In MGH SS XIII, edited by J. Heller and G. Waitz, 405-599. Hannover: Hahn, 1881.

Gregory of Tours. "Historiarum libri X." In MGH SRM I-I, edited by Bruno Krusch and Wilhelm Levison, 1-537. Hannover: Hahn, 1951.

Gysseling, Maurits, and A.C.F. Koch, eds. Diplomata Belgica ante annum millesimum centesimum scripta. Brussels: BIUCN, 1950.

Hampe, Karl, ed. "Leonis III. papae epistolae X.” In MGH Epp. V, 85-104. Berlin: Weidmann, 1899.

Hartmann, Wilfried, ed. Die Konzilien der karolingischen Teilreiche (860-874). MGH Conc. IV. Hannover: Hahn, 1998.

Heiric. "Vita sancti Germani episcopi Antissiodorensis." In PL CXXIV, edited by Jacques-Paul Migne, cols. 1131-1208. Montrouge: Migne, 1852.

Herlihy, David, ed. The History of Feudalism. London: Macmillan, 1970.

Hildegar. "Vita Faronis episcopi Meldensis." In MGH SRMV , edited by Bruno Krusch and W. Levison, 171-203. Hannover: Hahn, 1910. 
Hincmar. "Epistolae." In PL CXXVI, edited by Jacques-Paul Migne, cols. 9-280. Montrouge: Migne, 1852.

Holder-Egger, O., ed. "Miracula sancti Bertini Sithiensia.” In MGH SS XV-I, 507-522. Hannover: Hahn, 1887.

—, ed. "Miracula sancti Richarii." In MGH SS XV-II, 915-919. Hannover: Hahn, 1888.

- ed. "Sermo de relatione corporis beati Vedasti." In MGH SS XV-I, 402-404. Hannover: Hahn, 1887.

Ibn Fadlan, Ahmad. Mission to the Volga. Translated by J. Montgomery. New York: NYU Press, 2017.

Irvine, Susan, ed. The Anglo-Saxon Chronicle: A Collaborative Edition-MS E. Cambridge: Brewer, 2004.

Kehr, P., ed. MGH Karoli III. diplomata. Berlin: Weidmann, 1937.

Krusch, Bruno, ed. "Miracula Martini abbatis Vertavensis." In MGH SRM III, 564-575. Hannover: Hahn, 1896.

— ed. "Vita Columbani abbatis discipulorumque eius." In MGH SRM IV , 1-152. Hannover: Hahn, 1902.

Kurze, Friedrich, ed. Annales Fuldenses. MGH SR GVII. Hannover: Hahn, 1891.

- ed. Annales regni francorum et annales qui dicuntur Einhardi. MGH SRG VI. Hannover: Hahn, 1895.

—, ed. Reginonis abbatis Prumiensis chronicon. MGH SR G L. Hannover: Hahn, 1890. Labbé, Philippe, and Gabriel Cossart, eds. "Vita et epistolae Ioannis papae IX." In Sacrosancta concilia ad Regiam editionem exacta, IX: cols. 482-502. Paris: Societas Typographica Librorum Ecclesiasticorum, 1671.

Lauer, Philippe, ed. Recueil des actes de Charles III le Simple, roi de France (893-923). Paris: Imprimerie Nationale, 1949.

— Nationale, 1914.

Lebecq, Stéphane, ed. Marchands et navigateurs frisons du haut Moyen Age. Vol. II. Lille: Presses Universitaires de Lille, 1983.

Lot, Ferdinand, ed. Chronique de l'abbaye de Saint-Riquier. Paris: Picard et Fils, 1894.

Lupus Servatus. "Epistolae." In MGH Epp. VI, edited by Ernst Dümmler, 1-126. Berlin: Weidmann, 1925.

Mac Airt, Seán, and Gearóid Mac Niocaill, trans. The Annals of Ulster. Dublin: Institute for Advanced Studies, 1983.

MacLean, Simon, trans. History and Politics in Late Carolingian and Ottonian Europe: The Chronicle of Regino of Prüm and Adalbert of Magdeburg. Manchester: Manchester University Press, 2009.

Martène, Edmond, and Ursin Durand, eds. Veterum scriptorum et monumentorum historicum dogmaticorum, moralium.Vol. I. Paris: Montalant, 1724.

McKinney, Mary, trans. The Saxon Poet's Life of Charles the Great. New York: Pageant Press, 1956.

Merlet, René, ed. Chronique de Nantes. Paris: Picard et Fils, 1896.

Migne, Jacques-Paul, ed. "Caroli calvi epistolae." In PL CXXIV, cols. 861-896. Montrouge: Migne, 1852.

- ed. "Diploma Christophori." In PL CXXXI, cols. 45-48. Montrouge: Migne, 1853.

, ed. "Nicolai papae I: Epistolæ et decreta." In PL CXIX, cols. 769-1182. Montrouge: Migne, 1852. 
Mühlbacher, Engelbert, ed. MGH DD Kar. I. Hannover: Hahn, 1906.

Müller,Ernest, ed. Nithardi historiarum libri IIII. MGH SR G XLIV.Hannover: Hahn, 1907.

Muller, S., and A.C. Bouman, eds. Oorkondenboek van het Sticht Utrecht tot 1301. Vol. 1. Utrecht: Oosthoek, 1920.

Nelson, Janet, trans. The Annals of St. Bertin. Manchester: Manchester University Press, 1991.

Noble, Thomas, trans. "The Deeds of Emperor Charles the Great." In Charlemagne and Louis the Pious, 59-118. University Park, PA: Pennsylvania State University Press, 2009.

- trans. "The Life of Charles the Emperor." In Charlemagne and Louis the Pious, 21-50. University Park, PA: Penn State University Press, 2009.

_ 302. University Park, PA: Pennsylvania State University Press, 2009.

Notker. Gesta Karoli magni imperatoris. Edited by Hans Haefele. MGH SRG NS XII. Berlin: Weidmann, 1959.

Paschasius Radbert. Expositio in Lamentationes Hieremiae libri quinque. Edited by Paulus Beda.Turnhout: Brepols, 1988.

Perels, Ernst, ed. Hincmari archiepiscopi Remensis epistolae. MGH Epp. VIII, i. Berlin: Weidmann, 1939.

Pertz, Georg Heinrich, ed. "Annales Engolismenses." In MGH SS XVI, 485-487. Hannover: Hahn, 1859.

— - ed. “Annales Vedastini.” In MGH SS II, 196-209. Hannover: Hahn, 1829.

_ ed. “Annales Xantenses.” In MGH SS II, 217-236. Hannover: Hahn, 1829.

— ed. "Chronicon Moissiacense.” In MGH SS I, 280-313. Hannover: Hahn, 1826.

—, ed. "Fragmentum chronici Fontanellensis." In MGH SS II, 301-304. Hannover: Hahn, 1829.

— ed. MGH Diplomatum Imperii I. Hannover: Hahn, 1872.

— ed. "Vita sancti Rimberti archiepiscopi Hammaburgensis." In MGH SS II, 764775. Hannover: Hahn, 1829.

Poeta Saxo. "Annalium de gestis Caroli magni imperatoris." In MGH Poetae IV, edited by Paul von Winterfeld, 1-71. Berlin: Weidmann, 1899.

Poupardin, René, ed. Recueil des chartes de l'abbaye de Saint-Germain-des-Prés. Vol. I. Paris: Champion, 1909.

Regenos, Graydon W., trans. The Letters of Lupus of Ferrières. The Hague: Martinus Nijhoff, 1966.

Reuter, Timothy, trans. The Annals of Fulda. Manchester: Manchester University Press, 1992.

Rimbert. Vita Anskarii. Edited by G. Waitz. MGH SR G LV. Hannover: Hahn, 1884.

Robinson, Charles H., trans. Anskar: The Apostle of the North. London: SPG, 1921.

Ruotger. Vita Brunonis archiepiscopi Coloniensis. MGH SR G NS X. Weimar: Böhlau, 1951.

Samnordisk runtextdatabas. Uppsala University, 2014. www.nordiska.uu.se/forskn/ samnord.htm.

Schieffer, Theodor, ed. MGH DD Kar. III: Lotharii I. et Lotharii II. diplomata. Berlin: Weidmann, 1966.

Scholz, Bernhard Walter, trans. Carolingian Chronicles: Royal Frankish Annals and Nithard's Histories. Ann Arbor: University of Michigan Press, 1972.

Sedulius Scottus. "Item de quodam altari.” In MGH Poetae III, edited by Ludwig Traube, 209-210. Berlin: Weidmann, 1896. 
Societas Aperiendis Fontibus Rerum Germanicarum Medii Aevi, eds. MGH Diplomatum regum et imperatorum Germaniae. Vol. I, Conradi I. Heinrici I. et Ottonis I. diplomata. Hannover: Hahn, 1879-1884.

Sot, Michel, Guy Lobrichon, and Monique Goullet, eds. Les Gestes des évêques d'Auxerre. Vol. I. Paris: Les Belles Lettres, 2002.

Swanton, Michael, trans. The Anglo-Saxon Chronicle. London: J.M. Dent, 1996.

Talbot, C.H., trans. "The Life of Saint Willibrord." In Soldiers of Christ: Saints and Saints' Lives from Late Antiquity and the Early Middle Ages, edited by Thomas Noble and Thomas Head, 189-211. University Park, PA: Pennsylvania State University Press, 1995.

Tangl,Michael,ed.Sancti Bonifatiiet Lulliepistolae.MGHEpp.sel.I.Berlin: Weidmann, 1916. Tessier, Georges, ed. Recueil des actes de Charles II le Chauve, roi de France. Vol. II. Paris: Imprimerie Nationale, 1952.

Thegan. "Vita Hludowici imperatoris." In MGH SS II, edited by Georg Heinrich Pertz, 585-604. Hannover: Hahn, 1829.

“Translatio sancti Germani Parisiensis.” Analecta Bollandiana 2 (1883): 69-98.

Tschan, Francis, trans. History of the Archbishops of Hamburg-Bremen. 2nd ed. New York: Columbia University Press, 2002.

Venantius Fortunatus. Carminum epistularum expositionum. Edited by Friedrich Leo. MGH AA IV-I. Berlin: Weidmann, 1881.

von Simson,Bernhard,ed.Annales Mettenses priores.MGH SR GX. Hannover: Hahn, 1905. Waitz, G., ed. Annales Bertiniani. MGH SRG V. Hannover: Hahn, 1883.

Weiland, Ludwig, ed. "Synodus Ingelheimensis." In MGH Const. I, 8-16. Hannover: Hahn, 1843.

Widukind. Rerum gestarum Saxonicarum. Edited by G. Waitz and K.A. Kehr. MGH SRG LX. Hannover: Hahn, 1935.

\section{Secondary sources}

Abrams, Lesley. "Early Normandy." In Anglo-Norman Studies XXXV: Proceedings of the Battle Conference 2012, edited by David Bates, 45-64. Woodbridge: Boydell, 2013.

Airlie, Stuart. "The Palace of Memory: The Carolingian Court as Political Centre." In Courts and Regions in Medieval Europe, edited by Sarah Rees Jones, Richard Marks, and A.J. Minnis, 1-20. York: York Medieval Press, 2000.

Ambrosiani, Björn. "Birka and Dorestad." In In Discussion with the Past, edited by $\mathrm{H}$. Sarfatij and W.J.H.Verwers, 239-242. Zwolle: SPA, 1999.

_ . "Regalia and Symbols in the Boat-Graves." In Vendel Period Studies: Transactions of the Boat-Grave Symposium in Stockholm, Feb 2-3, 1981, edited by Jan Peder Lamm and H. Nordström, 23-30. Stockholm: Museum of National Antiquities, 1983.

Andersson, Hans. "Urbanisation." In The Cambridge History of Scandinavia, edited by Knut Helle, I:312-342. Cambridge: Cambridge University Press, 2003.

Andersson, Theodore. "The Viking Image in Carolingian Poetry." In Les relations littéraires franco-scandinaves au Moyen Âge, edited by Maurice Gravier Delbouille, 217246. Paris: Les Belles Lettres, 1975.

Andrén, Anders. "State and Towns in the Middle Ages: The Scandinavian Experience." Theory and Society 18, no. 5 (1989): 585-609.

Arbman, Holger, and Nils-Ove Nilsson. "Armes scandinaves de l'époque viking en France." Meddelanden från Lunds universitets historiska museum 1966-1968 (1969): 163-202. 
Armstrong, Simon. "Carolingian Coin Hoards and the Impact of the Viking Raids in the Ninth Century." Numismatic Chronicle 158 (1998): 131-164.

Arrhenius, Birgit. "The Chronology of the Vendel Graves." In Vendel Period Studies: Transactions of the Boat-Grave Symposium in Stockholm, Feb 2-3, 1981, edited by Jan Peder Lamm and H. Nordström, 39-70. Stockholm: Statens Historiska Museum, 1983.

Ashby, Steven. "What Really Caused the Viking Age? The Social Content of Raiding and Exploration." Archaeological Dialogues 22 (2015): 89-106.

Ashby, Steven, Ashley Coutu, and Søren Sindbæk. "Urban Networks and Arctic Outlands: Craft Specialists and Reindeer Antler in Viking Towns." European Journal of Archaeology 18, no. 4 (2015): 679-704.

Axboe, Morten. "Towards the Kingdom of Denmark." Anglo-Saxon Studies in Archaeology and History 10 (1999): 109-118.

Baastrup, Maria. "Continental and Insular Imports in Viking Age Denmark: On Transcultural Competences, Actor Networks and High-Cultural Differentiation." In Northern Worlds: Landscapes, Interactions and Dynamics, edited by Hans Christian Gulløv, 353-367. Copenhagen: National Museum of Denmark, 2014.

Bachrach, Bernard S. "Military Lands in Historical Perspective." Haskins Society Journal 9 (1997): 95-122.

- "Military Organization in Aquitaine under the Early Carolingians." Speculum 49 (1974): 1-33.

Bairoch, Paul, Jean Batou, and Pierre Chèvre. La population des villes européennes: banque de données et analyse sommaire des résultats, 800-1850. Geneva: Droz, 1988.

Baker, John, and Stuart Brookes. Beyond the Burghal Hidage: Anglo-Saxon Civil Defence in the Viking Age. Leiden: Brill, 2013.

Barrett, James H. ed. Contact, Continuity, and Collapse: The Norse Colonization of the North Atlantic. Turnhout: Brepols, 2003.

—. "What Caused the Viking Age?" Antiquity 82 (2008): 671-685.

Bartels, Michiel. De Deventer wal tegen de Vikingen. Deventer: Gemeente Deventer, 2006.

Bartels, Michiel, and Michel Groothedde. "Central Places and Fortifications: The Case Study of Deventer and Zutphen - A Medieval Burgenordnung in the Eastern Netherlands?" In Trade and Communication Networks of the First Millennium AD in the Northern Part of Central Europe, edited by Babette Ludowici, Hauke Jöns, Sunhild Kleingärtner, Jonathan Scheschkewitz, and Matthias Hardt, 238-254. Hannover: Niedersächsisches Landesmuseum, 2010.

Barton, Richard. Lordship in the County of Maine, c. 890-1160. Woodbridge: Boydell, 2004. Bates, David. Normandy before 1066. Harlow: Longman, 1982.

_. "West Francia: The Northern Principalities." In The New Cambridge Medieval History, edited by Timothy Reuter, III:398-419. Cambridge: Cambridge University Press, 2000.

Bazelmans, Jos. By Weapons Made Worthy: Lords, Retainers and their Relationship in Beowulf. Amsterdam: Amsterdam University Press, 1999.

Bauduin, Pierre. Le monde franc et les Vikings: VIII $-X^{e}$ siècle. Paris: Albin Michel, 2009.

- Les Vikings. Paris: Presses Universitaires de France, 2018.

Baug, Irene, Dagfinn Skre, Tom Heldal, and Øystein J. Jansen. "The Beginning of the Viking Age in the West.” Journal of Maritime Archaeology 14 (2019): 43-80.

Behr, Charlotte. "Using Bracteates as Evidence for Long-Distance Contacts." In Incipient Globalisation? Long-Distance Contacts in the Sixth Century, edited by Anthea Harris, 15-25. Oxford: BAR, 2007. 
Bendixen, Kirsten. "Sceattas and Other Coin Finds." In Ribe Excavations 1970-76, edited by Mogens Bencard, 1:63-101. Esbjerg: Sydjysk Universitersforlag, 1981.

Berke, Hubert. "Haustiere, Handwerker und Händler: Vorläufige archäozoologische Ergebnisse der Ausgrabungen am Heumarkt in Köln." Kölner Jahrbuch 30 (1997): 405-413.

Besteman, Jan. "Carolingian Medemblik." Berichten van de Rijksdienst voor het Oudheidkundig Bodemonderzoek 24 (1974): 43-106.

—_. "Nieuwe Vikingvondsten van Wieringen: de zilverschat Westerklief II." In Middeleeuwse toestanden: archeologie, geschiedenis en monumentenzorg, edited by P.J. Woltering, W.J.H.Verwers, and G.H. Scheepstra, 65-75. Hilversum: Verloren, 2002.

__. "Scandinavisch gewichtsgeld in Nederland in de Vikingperiode." In Van Solidus tot Euro: Geld in Nederland in economisch-historisch en politiek perspectief, edited by E.H.P. Cordfunke and Herbert Sarfatij, 21-42. Hilversum: Verloren, 2004.

."Viking Silver on Wieringen." In In Discussion with the Past, edited by Herbert Sarfatij, 253-266. Zwolle: SPA, 1999.

Biddle, Martin, and Birthe Kjølbye-Biddle. "Repton and the Vikings." Antiquity 66 (1992): 36-51.

Biggs, Frederick. "History and Fiction in the Frisian Raid." In The Dating of Beowulf: $A$ Reassessment, 138-156. Woodbridge: Boydell \& Brewer, 2014.

Bill, Jan. "Nails." In Woodstown: A Viking-Age Settlement in Co. Waterford, edited by Ian Russell and Maurice Hurley, 141-155. Dublin: Four Courts, 2014.

Binding, Günther. "Spätkarolingisch-ottonische Pfalzen und Burgen am Niederrhein." Château Gaillard: études de castellologie médiévale V (1972): 23-35.

Black, Iain S. "Analysing Historical and Archival Sources." In Key Methods in Geography, edited by Nicholas Clifford, Shaun French, and Gill Valentine, 466-484. 2nd ed. London: SAGE, 2010.

Blackburn, Mark. "Money and Coinage." In The New Cambridge Medieval History, edited by Rosamond McKitterick, II:538-559. Cambridge: Cambridge University Press, 1995.

Blary, F., andV. Blary. “Château-Thierry (Aisne): 'le vieux château.”' Archéologie médiévale 23 (1993): 417-419.

Bley, Matthias. "Viking Defilement in Early Medieval Francia." In Discourses of Purity in Transcultural Perspective (300-1600), edited by Matthias Bley, Nikolas Jaspert, and Stefan Köck, 203-239. Leiden: Brill, 2015.

Bloch, Marc. La société féodale. Paris: Albin Michel, 1939.

Bocquet, Anne, Kristell Chuniaud, and Chuniaud Naveau. "Le quartier antique de la Grande-Boissière à Jublains (Mayenne)." Revue archéologique de l'Ouest 21 (2004): 131-174.

Borger, Hugo, and Friedrich Oediger. Beiträge zur Frühgeschichte des Xantener Viktorstiftes. Düsseldorf: Rheinland-Verlag, 1969.

Bosl, Karl. "Pfalzen und Forsten." In Deutsche Königspfalzen, edited by Hermann Heimpel, I:1-29. Göttingen: Vandenhoeck \& Ruprecht, 1963.

Bouchard, Constance. "The Carolingian Creation of a Model of Patrilineage." In Paradigms and Methods in Early Medieval Studies, edited by Celia Chazelle and Felice Lifshitz, 135-151. Basingstoke: Palgrave Macmillan, 2007.

- Those of My Blood: Creating Noble Families in Medieval Francia. Philadelphia: University of Pennsylvania Press, 2001.

Brink, Stefan. "Skiringssal, Kaupang, Tjølling: The Toponymic Evidence.” In Kaupang in Skiringssal, edited by Dagfinn Skre, 53-64. Aarhus: Aarhus University Press, 2007. 
"Who Were the Vikings?" In The Viking World, edited by Stefan Brink and Neil Price, 4-7. London: Routledge, 2008.

Brøndsted, Johannes. Die große Zeit der Wikinger. Neumünster: Wachholtz, 1964.

Brooks, N.P. "England in the Ninth Century: The Crucible of Defeat." Transactions of the Royal Historical Society 29 (1979): 1-20.

Bruand, Olivier. "Pénétration et circulation du sel de l'Atlantique en France septentrionale (VIII $-\mathrm{XI}^{\mathrm{e}}$ siècles)." Annales de Bretagne et des pays de l'Ouest 114, no. 3 (2008): 2-23.

Brunet, Roger. Sustainable Geography. Hoboken, NJ: Wiley, 2010.

Bullough, D.A. Carolingian Renewal: Sources and Heritage. Manchester: Manchester University Press, 1991.

Callmer, Johan. "Archaeological Sources for the Presence of Frisian Agents of Trade in Northern Europe ca.AD 700-900." In Studien zur Archäologie des Ostseeraumes: von der Eisenzeit zum Mittelalter, edited by A.Wesse, 469-481. Neumünster: Wachholtz, 1998.

__. "Scandinavia and the Continent in the Viking Age." In The Viking World, edited by Stefan Brink and Neil Price, 439-452. London: Routledge, 2008.

_ . "Urbanisation in Northern and Eastern Europe, ca. AD 700-1100." In PostRoman Towns, Trade and Settlement in Europe and Byzantium: The Heirs of the Roman West, edited by Joachim Henning, 233-270. Berlin: de Gruyter, 2007.

_ . "Urbanization in Scandinavia and the Baltic Region c. AD 700-1100: Trading Places, Centres and Early Urban Sites." In Developments around the Baltic and the North Sea in the Viking Age, edited by Björn Ambrosiani and Helen Clarke, 50-90. Stockholm: Riksantikvarieämbetet, 1994.

Callmer, Johan, and Julian Henderson. "Glassworking at Åhus, S. Sweden (Eighth Century AD)." Laborativ arkeologi 5 (1991): 143-154.

Capelle, Torsten. "Die Wikinger auf dem westeuropäischen Kontinent." Deutsches Schiffahrtsarchiv 29 (2006): 7-58.

Cardon, Thibault, Jens Christian Moesgaard, Richard Prot, and Philippe Schiesser. "Le premier trésor monétaire de type viking en France. Denier inédit d'Eudes pour Beauvais." Revue numismatique 6, no. 164 (2008): 21-40.

Carpentier, Vincent, and Cyril Marcigny. "L'imaginaire archéologique dans les représentations du phénomène viking en Normandie: faux ou usages de faux?”' In Les Vikings dans l'empire franc, edited by Élisabeth Ridel, 97-101. Bayeux: OREP, 2014.

Christiansen, Eric. The Norsemen in the Viking Age. Oxford: Blackwell, 2006.

Christys, Ann. Vikings in the South: Voyages to Iberia and the Mediterranean. London: Bloomsbury, 2015.

Claszen, David, and J.M.J.G. Kats. "Chronicon Moissiacense maius: A Carolingian World Chronicle.” MPhil Diss., Leiden University, 2012.

Coates, Richard. "New Light from Old Wicks: The Progeny of Latin Vicus." Nomina 22 (1999): 75-114.

Cochet, J.B.D. "Note sur des fibules scandinaves - Trouvées à Pîtres, près le Pont-del'Arche, et entrées au musée d'Antiquités de Rouen." In Précis analytique des travaux de l'Académie impériale des sciences, belles-lettres et arts de Rouen, 1869-1870, 408-420. Rouen: Boissel, 1870.

—_. "Une fouille en Normandie ou notice sur des sépultures chrétiennes: trouvées en mars 1871, a Saint-Ouen de Rouen." Revue archéologique 25 (1873): 86-100.

Collins, Roger. Charlemagne. Toronto: University of Toronto Press, 1998.

Cooijmans, Christian. "The Controlled Decline of Viking-Ruled Dorestad." Northern Studies 47 (2015): 32-46. 
Costambeys, Marios, Matthew Innes, and Simon MacLean. The Carolingian World. Cambridge: Cambridge University Press, 2011.

Coulson, Charles. "Fortresses and Social Responsibility in Late Carolingian France." Zeitschrift für Archäologie des Mittelalters 4 (1976): 29-36.

Coupland, Simon. "Carolingian Coinage and Scandinavian Silver." Nordisk numismatisk årsskrift (1986): 11-31.

. "Charlemagne's Coinage: Ideology and Economy." In Charlemagne: Empire and Society, edited by Joanna Story, 211-229. Manchester: Manchester University Press, 2005.

— . "From Poachers to Gamekeepers: Scandinavian Warlords and Carolingian Kings." Early Medieval Europe 7, no. 1 (1998): 85-114.

— . "Holy Ground? The Plundering and Burning of Churches by Vikings and Franks in the Ninth Century." Viator 45 (2014): 73-97.

. "Money and Coinage under Louis the Pious." Francia 17, no. 1 (1990): 23-54.

. "The Carolingian Army and the Struggle against the Vikings." Viator 35 (2004): 49-70.

__."The Coinage of Lothar I (840-855).” Numismatic Chronicle 161 (2001): 157-198.

. "The Fortified Bridges of Charles the Bald." Journal of Medieval History 17 (1991): 1-12.

. "The Frankish Tribute Payments to the Vikings and Their Consequences." Francia 26 (1999): 57-75.

. "The Rod of God's Wrath or the People of God's Wrath? - The Carolingian Theology of the Viking Invasions." Journal of Ecclesiastical History 42 (1991): 535-554.

—. "The Use of Coin in the Carolingian Empire in the Ninth Century." In Early Medieval Monetary History, edited by Rory Naismith, Martin Allen, and Elina Screen, 257-293. Farnham: Ashgate, 2014.

—. "The Vikings in Francia and Anglo-Saxon England to 911." In The New Cambridge Medieval History, edited by Rosamond McKitterick, II:190-201. Cambridge: Cambridge University Press, 1995.

—. "The Vikings on the Continent in Myth and History." History 88, no. 290 (2003): 186-203.

_. "Trading Places: Quentovic and Dorestad Reassessed." Early Medieval Europe 11, no. 3 (2002): 209-232.

Crawford, Barbara. Scandinavian Scotland. Leicester: Leicester University Press, 1987.

d'Haenens, Albert. Les invasions normandes, une catastrophe? Paris: Flammarion, 1970.

__. "Les invasions normandes dans l'empire franc au IX ${ }^{\mathrm{e}}$ siècle." In I Normanni e la loro espansione in Europa nell'alto medioevo, edited by Centro italiano di studi sull'alto medioevo, 233-298. Spoleto: Presso la Sede del Centro, 1969.

- Les invasions normandes en Belgique au IX Siècle. Louvain: Publications Universitaires de Louvain, 1967.

Daveau, Isabelle, andVincent Goustard. "Un complexe métallurgique et minier du haut Moyen Age: le site des Fourneaux à Vert-Saint-Denis (Seine-et-Marne)." Gallia 57 (2000): 77-99.

Davis, Jennifer. Charlemagne's Practice of Empire. Cambridge: Cambridge University Press, 2015.

De Beaurepaire, François. "La diffusion de la toponymie scandinave dans la Normandie ducale." Tabularia "Etudes" 2 (2002): 47-56.

De Boüard, Michel. "Sépultures énigmatiques á Réville (Manche)." Annales de Normandie 14, no. 2 (1964): 258-263. 


\section{Bibliography}

De Jong, Mayke. "Carolingian Monasticism: The Power of Prayer." In The New Cambridge Medieval History, edited by Rosamond McKitterick, II:622-653. Cambridge: Cambridge University Press, 1995.

_ . "Ecclesia and the Early Medieval Polity." In Staat im frühen Mittelalter, edited by Helmut Reimitz and Stuart Airlie, 113-126.Vienna: AASP, 2006.

De Meulenmeester, J. "Castrale motten in België." Archaeologia Belgica 255 (1983): 199-225.

—_. "Karolingische castra en stadsontwikkeling: enkele archaeo-topografische suggesties." In Ontstaan en vroegste geschiedenis van de middeleeuwse steden in de Zuidelijke Nederlanden, 118-156. Brussels: Gemeentekrediet, 1990.

Dearden, Brian, and Anthony Clark. "Pont-de-l'Arche or Pîtres? A Location and Archaeomagnetic Dating for Charles the Bald's Fortifications on the Seine." Antiquity 64, no. 244 (1990): 567-571.

Deckers, Pieterjan. "An Illusory Emporium? - Small Trading Places around the Southern North Sea." In Dorestad in an International Framework, edited by Annemarieke Willemsen and Hanneke Kik, 158-167. Turnhout: Brepols, 2010.

Depreux, Philippe. "A la recherche des défenseurs de la cité à l'époque carolingienne." Les petits cahiers d'Anatole 2 (2001): 2-19.

Desbordes, J.-M. “Informations archéologiques: Circonscription de Picardie." Gallia 33, no. 2 (1975): 291-318.

DeSelm, Daniel. "Unwilling Pilgrimage: Vikings, Relics, and the Politics of Exile during the Carolingian Era (c. 830-940).” PhD Diss., University of Michigan, 2009.

Devroey, Jean-Pierre. Économie rurale et société dans l'Europe franque (VI'-IX siècles): Tome I. Paris: Belin, 2003.

__. "Un monastère dans l'économie d'échanges: les services de transport à l'abbaye Saint-Germain-des-Prés au IX ${ }^{\text {e }}$ siècle." Annales: Histoire, Sciences Sociales 39, no. 3 (1984): 570-589.

Dijkman, Wim. "Artisanal Activities in Merovingian Maastricht." Medieval and Modern Matters 4 (2013): 23-39.

Dijkstra, Juke, Janneke Buurman, O. Goubitz, and KarelVlierman. Archeologisch onderzoek in de binnenstad van Tiel - juni t/m september 1996: Lokaties Koornmarkt en Tol-Zuid. Amersfoort: ROB, 1998.

Dijkstra, M.F.P. Rondom de mondingen van Rijn \& Maas. Leiden: Sidestone, 2011.

Dijkstra, M.F.P., and Tim de Ridder. "Circular Fortresses in the Provinces of North and South Holland (West Frisia)." In Ringwälle und verwandte Strukturen des ersten Jahrtausends n. Chr. an Nord- und Ostsee, edited by Martin Segschneider, 201-218. Neumünster: Wachholtz, 2009.

Dobat, Andres Siegfried. "Danevirke Revisited: An Investigation into Military and Socio-Political Organisation in South Scandinavia (c. AD 700 to 1100)." Medieval Archaeology 52, no. 1 (2008): 27-67.

Doherty, Charles. “The Viking Impact upon Ireland.” In The Vikings in Ireland, edited by Anne-Christine Larsen, 29-35. Roskilde: Viking Ship Museum, 2001.

Downham, Clare. "The Earliest Viking Activity in England?” English Historical Review CXXXII, no. 554 (2017): 1-12.

- "Viking Ethnicities: A Historiographic Overview." History Compass 10 (2012): 1-12.

- Viking Kings of Britain and Ireland: The Dynasty of Ívarr to A.D. 1014. Edinburgh: Dunedin, 2007. 
Duczko, Wladyslaw. Viking Rus': Studies on the Presence of Scandinavians in Eastern Europe. Leiden: Brill, 2004.

Dumont, Annie, Jean-François Mariotti, and Jean Soulat. "Taillebourg, une base viking sur la Charente? Le témoignage de l'archéologie." In Les Vikings dans l'empire franc, edited by Élisabeth Ridel, 42-49. Bayeux: OREP, 2014.

Dumville, David. "Images of the Viking in Eleventh-Century Latin Literature." In Latin Culture in the Eleventh Century, edited by Michael Herren, C.J. McDonough, and Ross Arthur, I:250-263. Turnhout: Brepols, 2002.

_. "Vikings in Insular Chronicling." In The Viking World, edited by Stefan Brink and Neil Price, 350-367. London: Routledge, 2008.

Dunbabin, Jean. France in the Making: 843-1180. 2nd ed. Oxford: Oxford University Press, 2000.

_ . "West Francia: The Kingdom." In The New Cambridge Medieval History, edited by Timothy Reuter, III:372-397. Cambridge: Cambridge University Press, 2000.

Duplessy, Jean. Les trésors monétaires médiévaux et modernes découverts en France. Vol. I. Paris: Bibliothèque nationale, 1985.

Eickhoff, Ekkehard. "Maritime Defence of the Carolingian Empire." In Vikings on the Rhine: Recent Research on Early Medieval Relations between the Rhinelands and Scandinavia, edited by Rudolf Simek and Ulrike Engel, 51-64.Vienna: Fassbaender, 2004.

Elmshäuser, Konrad, and Andreas Hedwig. Studien zum Polyptychon von Saint-Germaindes-Prés. Cologne: Böhlau, 1993.

Endemann, Traute. Markturkunde und Markt in Frankreich und Burgund vom 9. bis 11. Jahrhundert. Konstanz: Thorbecke, 1964.

Evison,Vera. "Le verre carolingien.” In À travers le verre: du Moyen Age à la Renaissance, edited by Danièle Foy and Geneviève Sennequier, 137-144. Rouen: Musées et Monuments departémentaux de la Seine-Maritime, 1989.

Fabech, Charlotte. "Centrality in Sites and Landscapes." In Settlement and Landscape: Proceedings of a Conference in Arhus, Denmark, May 4-7 1998, edited by Charlotte Fabech and Jytte Ringtved, 455-473. Moesgård: Jutland Archaeological Society, 1999.

Fabech, Charlotte, and Jytte Ringtved. "Magtens geografi i Sydskandinavian - Om kulturlanskab, produktion og bebyggelsesmønster." In Produksjon og samfunn: Om erverv, spesialisering og bosetning i Norden i 1. artusen e. Kr, edited by Heid Gjøstein Resi, 11-37. Oslo: Universitet i Oslo, 1995.

Fellows-Jensen, Gillian. "Scandinavian Place-Names and Viking Settlement in Normandy: A Review." Namn och bygd 76 (1988): 113-137.

Feveile, Claus. "Mayen Lava Quern Stones from the Ribe Excavations 1970-76.” In Ribe Excavations 1970-76, edited by Mogens Bencard and Helge Brinch Madsen, 6:133-156. Aarhus: Jutland Archaeological Society, 2010.

_. "Ribe: Emporia and Town in the 8th and 9th Century." In From One Sea to Another: Trading Places in the European and Mediterranean Early Middle Ages, edited by Sauro Gelichi and Richard Hodges, 111-122. Turnhout: Brepols, 2012.

—. "Ribe on the North Side of the River, 8th-12th Century: Overview and Interpretation.” In Det celdste Ribe: udgravninger på nordsiden af Ribe A 1984-2000 Bind 1, edited by Claus Feveile, 65-91. Højbjerg: Jysk Arkæologisk Selskab, 2006. ."'Series X and Coin Circulation in Ribe.”In Studies in Early Medieval Coinage I: Two Decades of Discovery, edited by Tony Abramson, 53-67. Woodbridge: Boydell, 2008. Viking Ribe: Trade, Power and Faith. Ribe: Sydvestjyske Museer, 2013. 


\section{Bibliography}

Feveile, Claus, and Stig Jensen. "Ribe in the 8th and 9th Century: A Contribution to the Archaeological Chronology of North Western Europe." Acta Archaeologica 71 (2000): 9-24.

Forte, Angelo, Richard Oram, and Frederik Pedersen. Viking Empires. Cambridge: Cambridge University Press, 2005.

Fouracre, Paul. "Frankish Gaul to 814." In The New Cambridge Medieval History, edited by Rosamond McKitterick, II:85-109. Cambridge: Cambridge University Press, 1995.

Fox, Yaniv. Power and Religion in Merovingian Gaul: Columbanian Monasticism and the Frankish Elites. Cambridge: Cambridge University Press, 2014.

Fraenkel-Schoorl, Neeke. "Carolingian Jewellery with Plant Ornament." Berichten van de Rijksdienst voor het Oudheidkundig Bodemonderzoek 28 (1978): 345-397.

Franklin, Simon, and Jonathan Shepard. The Emergence of Rus': 750-1200. Harlow: Longman, 1996.

Fried, Johannes. "Gens und Regnum: Wahrnehmungs- und Deutungskategorien politischen Wandels im früheren Mittelalter." In Sozialer Wandel im Mittelalter: Wahrn ehmungsformen, Erklärungsmuster, Regelungsmechanismen, edited by Jürgen Miethke and Klaus Schreiner, 73-104. Sigmaringen: Thorbecke, 1993.

_. "The Frankish Kingdoms, 817-911: The East and Middle Kingdoms." In The New Cambridge Medieval History, edited by Rosamond McKitterick, II:142-168. Cambridge: Cambridge University Press, 1995.

Fuglesang, Signe Horn. “Copying and Creativity in Early Viking Ornament.” In Early Medieval Art and Archaeology in the Northern World, edited by Andrew Reynolds and Leslie Webster, 825-841. Leiden: Brill, 2013.

_ . "Skriftlige kilder for karolingisk våpeneksport til Skandinavia?" Collegium Medievale 13 (2000): 177-184.

Ganshof, François-Louis. “À propos du tonlieu à l'époque carolingienne.” In La città nell'alto medioevo, edited by Centro italiano di studi sull'alto medioevo, 485-508. Spoleto: Presso la Sede del Centro, 1959.

- Frankish Institutions under Charlemagne. Providence: Brown University Press, 1968.

- Het tolwezen in het Frankisch rijk onder de Karolingen. Brussels: Paleis der Academiën, 1959.

- "The Impact of Charlemagne on the Institutions of the Frankish realm." Speculum 40, no. 1 (1965): 47-62.

Ganz, David. "Einhard's Charlemagne: The Characterisation of Greatness." In Charlemagne: Empire and Society, edited by Joanna Story,38-51.Manchester: Manchester University Press, 2005.

Garipzanov, Ildar H. "Frontier Identities: Carolingian Frontier and the Gens Danorum." In Franks, Northmen, and Slavs: Identities and State Formation in Early Medieval Europe, edited by Ildar H. Garipzanov, Patrick Geary, and Przemyslaw Urbanczyk, 113-143. Turnhout: Brepols, 2008.

Gaut, Bjarne. "Vessel Glass and Evidence of Glassworking." In Things from the Town: Artefacts and Inhabitants in Viking-Age Kaupang, edited by Dagfinn Skre, 169279. Aarhus: Aarhus University Press, 2011.

_. "Vessel Glass from Kaupang: A Contextual and Social Analysis." Norwegian Archaeological Review 40, no. 1 (2007): 26-41.

Gilchrist, Roberta. "Medieval Archaeology and Theory: A Disciplinary Leap of Faith." In Reflections: 50 Years of Medieval Archaeology, 19572007, edited by Roberta Gilchrist and Andrew Reynolds, 385-408. London: Maney, 2009. 
Gillmor, Carroll. "War on the Rivers: Viking Numbers and Mobility on the Seine and Loire, 841-886.” Viator 19 (1988): 79-109.

Glenn, Jason. Politics and History in the Tenth Century: The Work and World of Richer of Reims. Cambridge: Cambridge University Press, 2004.

Goldberg, Eric. Struggle for Empire: Kingship and Conflict under Louis the German, 817876. Ithaca: Cornell University Press, 2006.

Graham-Campbell, James, and Colleen Batey. Vikings in Scotland: An Archaeological Survey. Edinburgh: Edinburgh University Press, 1998.

Gratuze, Bernard, Danièle Foy, Joël Lancelot, and Florian Téreygeol. "Les 'lissoirs' carolingiens en verre au plomb: mise en évidence de la valorisation des scories issues du traitement des galènes argentiferes de Melle (Deux-Sèvres)." In Echanges et commerce du verre dans le monde antique, edited by Danièle Foy and Marie-Dominique Nenna, 101-107. Drémil-Lafage: Mergoil, 2003.

Green, Thomas. Trade, Gift-giving and Romanitas: A Comparison of the Use of Roman Imports in Western Britain and Southern Scandinavia. Louth: Lindes Press, 2009.

Grierson, Philip. "The 'Gratia Dei Rex' Coinage of Charles the Bald." In Charles the Bald: Court and Kingdom, edited by Margaret Gibson and Janet Nelson, 39-51. Oxford: BAR, 1981.

Grierson, Philip, and Mark Blackburn. European Medieval Coinage I: The Early Middle Ages (5th-10th Centuries). Cambridge: Cambridge University Press, 1986.

Groothedde, Michel. "De nederzettingsontwikkeling van Zutphen voor het jaar 1000.” In De Sint-Walburgiskerk in Zutphen: Momenten uit de geschiedenis van een middeleeuwse Kerk, 9-30. Zutphen: Walburg, 1999.

—_. "The Vikings in Zutphen (Netherlands)." In Vikings on the Rhine: Recent Research on Early Medieval Relations between the Rhinelands and Scandinavia, edited by Rudolf Simek and Ulrike Engel, 111-132.Vienna: Fassbaender, 2004.

Guillotel, Hubert. "Saint-Suliac: rencontre de l'archéologie, de la diplomatique, du droit et de l'hagiographie." Mémoires de la Société d'histoire et d'archéologie de Bretagne 76 (1998): 5-25.

Gullbekk, Svein H. “Coinage and Monetary Economies." In The Viking World, edited by Stefan Brink and Neil Price, 159-169. London: Routledge, 2008.

Gustin, Ingrid. "Islam, Merchants, or King? - Who Was behind the Manufacture of Viking Age Weights?” In Visions of the Past: Trends and Traditions in Swedish Medieval Archaeology, edited by Hans Andersson and Peter Carelli, 163-178. Stockholm: Riksantikvarieämbetet, 1997.

Gysseling, Maurits. Toponymisch woordenboek van België, Nederland, Luxemburg, NoordFrankrijk en West-Duitsland (vóór 1226). Brussels: BIUCN, 1960.

Hadley, Dawn, and Julian Richards. "The Winter Camp of the Viking Great Army, AD 872-3, Torksey, Lincolnshire.” Antiquaries Journal 96 (2016): 23-67.

Hagger, Mark. Norman Rule in Normandy: 911-1144. Woodbridge: Boydell, 2017.

Haggett, Peter, Andrew Cliff, and Allan Frey. Locational Analysis in Human Geography. 2nd ed. London: Edward Arnold, 1977.

Hall, Richard. Exploring the World of the Vikings. London: Thames \& Hudson, 2007.

Halsall, Guy. Warfare and Society in the Barbarian West, 450-900. London: Routledge, 2003.

Hamerow, Helena. Early Medieval Settlements: The Archaeology of Rural Communities in Northwest Europe, 400-900. Oxford: Oxford University Press, 2002.

Hårdh, Birgitta. "Hacksilver and Ingots." In Means of Exchange: Dealing with Silver in the Viking Age, edited by Dagfinn Skre, 95-118. Aarhus: Aarhus University Press, 2007. 
Hassall, J.M., and David Hill. "Pont de l'Arche: Frankish Influence on the West Saxon Burh?” Archaeological Journal 127 (1970): 188-195.

Haywood, John. Dark Age Naval Power: A Reassessment of Frankish and Anglo-Saxon Seafaring Activity. London: Routledge, 1991.

Heather, Peter. Empires and Barbarians. London: Pan Books, 2009.

Hedeager, Lotte. Iron Age Myth and Materiality: An Archaeology of Scandinavia AD 4001000. London: Routledge, 2011.

- Iron Age Societies: From Tribe to State in Northern Europe, 500 BC to AD 700. Translated by John Hines. Oxford: Blackwell, 1992.

—. "Scandinavia before the Viking Age." In The Viking World, edited by Stefan Brink and Neil Price, 11-22. London: Routledge, 2008.

Hedenstierna-Jonson, Charlotte. "Social and Political Formations in the Scandinavian Areas, 8th-10th Century: The Martial Perspective." Territorio, Sociedad y Poder 2 (2009): 89-104.

Heen-Pettersen,Aina Margrethe."The Earliest Wave of Viking Activity? The Norwegian Evidence Revisited.” European Journal of Archaeology 22, no. 4 (2019): 523-541.

Helle, Knut. "Introduction." In The Cambridge History of Scandinavia, edited by Knut Helle, I:1-12. Cambridge: Cambridge University Press, 2003.

Hen, Yitzak. "Knowledge of Canon Law among Rural Priests: The Evidence of Two Carolingian Manuscripts from around 800.' Journal of Theological Studies 50, no. 1 (1999): 117-134.

Henning, Joachim. "Early European Towns: The Development of the Economy in the Frankish realm between Dynamism and Deceleration AD 500-1100.” In Post-Roman Towns, Trade and Settlement in Europe and Byzantium: The Heirs of the Roman West, edited by Joachim Henning, 3-40. Berlin: de Gruyter, 2007.

Herschend, Frands. The Early Iron Age in South Scandinavia. Uppsala: Uppsala University, 2009.

Hill, David, David Barrett, Keith Maude, Julia Warburton, and Margaret Worthington. "Quentovic Defined." Antiquity 64 (1990): 51-58.

Hillerdal, Charlotta. "Early Urbanism in Scandinavia." In The Urban Mind: Cultural and Environmental Dynamics, edited by Paul J.J. Sinclair, Gullög Nordquist, Frands Herschend, and Christian Isendahl, 499-525. Uppsala: Uppsala University, 2010.

Hodges, Richard. Dark Age Economics: The Origins of Towns and Trade AD 600-1000. London: Duckworth, 1982.

—. "North Sea Trade before the Vikings." In Archaeological Approaches to Medieval Europe, edited by Kathleen Biddick, 193-201. Kalamazoo: Western Michigan University, 1984.

- "The 8th-Century Pottery Industry at La Londe, near Rouen, and its Implications for Cross-Channel Trade with Hamwic, Anglo-Saxon Southampton." Antiquity 65 (1991): 882-887.

Hodges, Richard, and David Whitehouse. Mohammed, Charlemagne \& the Origins of Europe. Duckworth, 1983.

Holmqvist, Wilhelm, and Birgit Arrhenius, eds. Excavations at Helgö I: Report for 19541956. Stockholm: Almqvist \& Wiksell, 1961.

Hudson, Benjamin. "Prologue: The Medieval Atlantic Ocean." In Studies in the Medieval Atlantic, edited by Benjamin Hudson, 1-32. New York: Palgrave Macmillan, 2012.

Hurley, Maurice. "Discussion and Conclusions." In Woodstown: A Viking-Age Settlement in Co. Waterford, edited by Ian Russell and Maurice Hurley, 347-357. Dublin: Four Courts, 2013. 
Hybel, Nils, and Bjørn Poulsen. The Danish Resources c. 1000-1550: Growth and Recession. Leiden: Brill, 2007.

Ilkjær, Jørgen. Illerup Ådal: Archaeology as a Magic Mirror. Højbjerg: Moesgård Museum, 2002.

Innes, Matthew. "People, Places and Power in Carolingian Society." In Topographies of Power in the Early Middle Ages, edited by Mayke de Jong and Frans Theuws. Leiden: Brill, 2001.

State and Society in the Early Middle Ages: The Middle Rhine Valley, 400-1000. Cambridge: Cambridge University Press, 2000.

Iversen, Frode. "Emerging Kingship in the 8th Century? New Datings of Three Courtyard Sites in Rogaland.” In Avaldsnes: A Sea-Kings' Manor in First-Millennium Western Scandinavia, edited by Dagfinn Skre, 721-746. Berlin: de Gruyter, 2018.

Jankuhn, Herbert. "Trade and Settlement in Central and Northern Europe up to and during the Viking Period." Journal of the Royal Society of Antiquaries of Ireland 112 (1982): 18-50.

Janssen, Walter. Die Importkeramik von Haithabu. Neumünster: Karl Wachholtz, 1987.

_. "Gewerbliche Produktion des Mittelalters als Wirtschaftsfaktor im ländlichen Raum." In Das Handwerk in vor- und frühgeschichtlicher Zeit: Archäologische und philologische Beiträge, edited by Herbert Jankuhn, Walter Janssen, Ruth SchmidtWiegand, and Heinrich Tiefenbach, 317-394. Göttingen: Vandenhoeck \& Ruprecht, 1983.

Jeanneau, Cédric. "Les moines de Saint-Philibert de Noirmoutier et les invasions scandinaves.” In Landévennec: les Vikings et la Bretagne, edited by Magali Coumert and Yvon Tranvouez, 241-242. Brest: Université de Bretagne Occidentale, 2015.

Jellema, Dirk. "Frisian Trade in the Dark Ages." Speculum 30, no. 1 (1955): 15-36.

Jesch, Judith. Ships and Men in the Late Viking Age: The Vocabulary of Runic Inscriptions and Skaldic Verse. Woodbridge: Boydell, 2001.

- The Viking Diaspora. Abingdon: Routledge, 2015.

—. "Vikings on the European Continent in the Late Viking Age." In Scandinavia and Europe 800-1350: Contact, Conflict, and Coexistence, edited by Jonathan Adams and Katherine Holman, 255-268. Turnhout: Brepols, 2004.

Jesset, Sébastien, and Patrice Georges. "Sorigny (Indre-et-Loire): Nétilly." Archéologie médiévale 34 (2004): 203-204.

Johansen, R. “The Viking Ships of Skuldelev." In Sailing into the Past: Learning from Replica Ships, edited by Jenny Bennett, 52-69. Barnsley: Seaforth, 2009.

Jørgensen, Anne Nørgård. "Danish Naval Complexes in the Late Iron Age and Viking Age: The GudsøVig Barrage in Perspective.” In The Martial Society: Aspects of Warriors, Fortifications and Social Change in Scandinavia, edited by Lena Holmquist Olausson and Michael Olausson, 79-92. Stockholm: Stockholm University, 2009.

—. "Naval Bases in Southern Scandinavia from the 7th to the 12th Century." In Maritime Warfare in Northern Europe: Technology, Organisation, Logistics and Administration 500 BC-1500 AD, edited by Anne Nørgård Jørgensen, John Pind, Lars Jørgensen, and Birthe Clausen, 125-152. Copenhagen: National Museum, 2002.

Jørgensen,Lars. "Manor and Market at Lake Tissø in the Sixth to Eleventh Centuries : The Danish 'Productive' Sites." In Markets in Early Medieval Europe: Trading and "Productive" Sites, 650-850, edited by Tim Pestell and Katharina Ulmschneider, 175-207. Macclesfield: Windgather Press, 2000.

Juel, Christian, and Mads Ravn. "Erritsø - A Fortified Early Viking Age Manor near Lillebælt." In The Fortified Viking Age, edited by Jesper Hansen and Mette Bruus, 16-25. Odense: University Press of Southern Denmark, 2018. 
Kelly, Eamonn. "The Longphort in Viking-Age Ireland: The Archaeological Evidence." In The Vikings in Ireland and Beyond: Before and After the Battle of Clontarf, edited by Howard Clarke and Ruth Johnson, 55-92. Dublin: Four Courts, 2015.

Kilger, Christoph. "Kaupang from Afar: Aspects of the Interpretation of Dirham Finds in Northern and Eastern Europe between the Late 8th and Early 10th Centuries." In Means of Exchange: Dealing with Silver in the Viking Age, edited by Dagfinn Skre, 199-252. Aarhus: Aarhus University Press, 2007.

. "Wholeness and Holiness: Counting, Weighing and Valuing Silver in the Early Viking Period." In Means of Exchange: Dealing with Silver in the Viking Age, edited by Dagfinn Skre, 253-325. Aarhus: Aarhus University Press, 2007.

Kleingärtner, Sunhild, and Gareth Williams. "Contacts \& Exchange." In Vikings: Life and Legend, edited by Gareth Williams, Peter Pentz, and Matthias Wemhoff, 28-69. London: British Museum Press, 2014.

Knibbs, Eric. Ansgar, Rimbert and the Forged Foundations of Hamburg-Bremen. Farnham: Ashgate, 2011.

Koch, Ursula. "Nordeuropäisches Fundmaterial in Gräbern Süddeutschlands rechts des Rheins." In Völker an Nord- und Ostsee und die Franken, edited by Uta von Freeden, Ursula Koch, and Alfried Wieczorek, 175-194. Bonn: Habelt, 1999.

Kosto, Adam. "Hostages in the Carolingian World (714-840)." Early Medieval Europe 11, no. 2 (2002): 123-147.

- Hostages in the Middle Ages. Oxford: Oxford University Press, 2012.

Kovalev, Roman K., and Alexis C. Kaelin. "Circulation of Arab Silver in Medieval AfroEurasia: Preliminary Observations.” History Compass 5, no. 2 (2007): 560-580.

Koziol, Geoffrey. "Charles the Simple, Robert of Neustria, and the Vexilla of SaintDenis.” Early Medieval Europe 14, no. 4 (2006): 355-390.

Kuchenbuch, Ludolf. Bäuerliche Gesellschaft und Klosterherrschaft im 9. Jahrhundert: Studien zur Sozialstruktur der Familia der Abtei Prüm. Wiesbaden: Steiner, 1978.

Kurrild-Klitgaard, Peter, and Gert Svendsen. "Rational Bandits: Plunder, Public Goods, and the Vikings." Public Choice 117 (2003): 255-272.

Langouët, Loïc. "Un retranchement normand 'insulaire': Gardaine à Saint-Suliac (Illeet-Vilaine)." Bulletin de l'AMARAI 4 (1991): 55-63.

Lawrence, C.H. Medieval Monasticism. 3rd ed. Harlow: Pearson, 2001.

Le Gentilhomme, P."The Circulation of Sceats in Merovingian Gaul.” British Numismatic Journal 24 (1944): 195-210.

Le Maho, Jacques. “La Seine et les Normands avant 911.” In Naissance de la Normandie911: le traité de Saint-Clair-sur-Epte, edited by Michel Pierre, 19-34. Paris: SPM, 2013.

__. "Les fouilles de la cathédrale de Rouen de 1985 à 1993: esquisse d'un premier bilan." Archéologie médiévale 24 (1994): 1-49.

_- "Les Normands dans la vallée de la Seine (IX $-\mathrm{X}^{\mathrm{e}}$ siècles)." In Les Vikings en France: une synthèse inédite, 277:26-33. Dossiers Archéologie. Dijon: Faton, 2002.

_ . "The Fate of the Ports of the Lower SeineValley at the End of the Ninth Century."

In Markets in Early Medieval Europe: Trading and "Productive" Sites, 650-850, edited by Tim Pestell and Katharina Ulmschneider, 234-247. Macclesfield: Windgather Press, 2003.

Lebecq, Stéphane. "L'emporium proto-médiéval de Walcheren-Domburg: une mise en perspective." In Peasants and Townsmen in Medieval Europe, edited by Jean-Marie Duvosquel and Erik Thoen, 73-89. Ghent: Snoeck-Ducaju, 1995.

_ . "Long Distance Merchants and the Forms of TheirVentures at the Time of the Dorestad Heyday." In In Discussion with the Past, edited by Herbert Sarfatij, 233-238. Zwolle: SPA, 1999. 
. Marchands et navigateurs frisons du haut Moyen Âge. Vol. I. Lille: Presses Universitaires de Lille, 1983.

. "Routes of Change: Production and Distribution in the West (5th-8th Century)." In The Transformation of the Roman World: AD 400-900, edited by Leslie Webster and Michelle Brown, 67-78. London: British Museum Press, 1997.

. "The New Wiks or Emporia and the Development of a Maritime Economy in the Northern Seas (7th-9th Centuries)." In From One Sea to Another: Trading Places in the European and Mediterranean Early Middle Ages, edited by Sauro Gelichi and Richard Hodges, 11-21. Turnhout: Brepols, 2012.

. "The Role of the Monasteries in the Systems of Production and Exchange of the Frankish World between the Seventh and the Beginning of the Ninth Century." In The Long Eighth Century: Production, Distribution and Demand, edited by Inge Lyse Hansen and Chris Wickham, 121-148. Leiden: Brill, 2000.

Lepelley, René. "Traces des Vikings dans la toponymie actuelle de la Normandie." Annales de Normandie 52, no. 3 (2002): 195-223.

Lewis, Stephen M. "Salt and the Earliest Scandinavian Raids in France: Was there a Connection?" Viking and Medieval Scandinavia 12 (2016): 103-136.

Linebaugh, Peter, and Marcus Rediker. The Many-Headed Hydra: Sailors, Slaves, Commoners, and the Hidden History of the Revolutionary Atlantic. Boston: Beacon Press, 2000.

Ljungkvist, John. "Continental Imports to Scandinavia: Patterns and Changes between AD 400 and 800." In Foreigners in Early Medieval Europe, edited by Dieter Quast, 2750. Mainz: Römisch-Germanischen Zentralmuseum, 2009.

Lot, Ferdinand. "La grande invasion normande de 856-862." Bibliothèque de l'École des Chartes 69 (1908): 5-62.

Louis, Étienne. "Wandignies-Hamage (Nord): Ancienne Abbaye." Archéologie médiévale 30-31 (2001): 277-278.

Loveluck, Christopher. Northwest Europe in the Early Middle Ages, c. AD 600-1150: A Comparative Archaeology. Cambridge: Cambridge University Press, 2013.

Loveluck, Christopher, and Dries Tys. "Coastal Societies, Exchange and Identity along the Channel and Southern North Sea Shores of Europe, AD 600-1000." Journal of Maritime Archaeology 1 (2006): 140-169.

Lund, Niels. "Allies of God or Man: The Viking Expansion in a European Perspective." Viator 20 (1989): 45-59.

MacLean, Simon. Kingship and Politics in the Late Ninth Century: Charles the Fat and the End of the Carolingian Empire. Cambridge: Cambridge University Press, 2003.

Malmer, Brita. "South Scandinavian Coinage in the Ninth Century." In Silver Economy in the Viking Age, edited by James Graham-Campbell and Gareth Williams, 13-27. Walnut Creek: Left Coast Press, 2007.

Marcigny, Cyril. "Le rempart du "Hague Dike »: une limite territoriale de l'âge du Bronze." Archéologie, histoire et anthropologie de la presqu'île de la Hague 10 (2016): 23-45.

Martin, Jean-François. "Sissonne (Aisne). Jeoffrécourt." Archéologie médiévale 27 (1997): 265.

Martindale, Jane. "The Kingdom of Aquitaine and the 'Dissolution of the Carolingian Fisc."” Francia 11 (1983): 131-191.

Maund, K.L. "“A Turmoil of Warring Princes': Political Leadership in Ninth-Century Denmark." Haskins Society Journal 6 (1994): 29-47.

Mauss, Marcel. The Gift: The Form and Reason for Exchange in Archaic Societies. Translated by W.D. Halls. London: Routledge, 1990. 
Mazet-Harhoff, Laurent. "Sur la trace desVikings en Haute-Normandie: problématique." In La progression des Vikings, des raids à la colonisation, edited by Anne-Marie Flambard Héricher, 119-151. Rouen: Université de Rouen, 2003.

- "The Incursion of the Vikings into the Natural and Cultural Landscape of Upper Normandy." In Viking Trade and Settlement in Continental Western Europe, edited by Iben Skibsted Klæsøe, 81-122. Copenhagen: Museum Tusculanum Press, 2010.

McCormick, Michael. Eternal Victory: Triumphal Rulership in Late Antiquity, Byzantium, and the Early Medieval West. Cambridge: Cambridge University Press, 1986.

—_. "New Light on the 'Dark Ages': How the Slave Trade Fuelled the Carolingian Economy." Past and Present 177, no. 1 (2002): 17-54.

- Origins of the European Economy: Communications and Commerce AD 300-900. Cambridge: Cambridge University Press, 2001.

McKitterick, Rosamond. "A King on the Move: The Place of an Itinerant Court in Charlemagne's Government." In Royal Courts in Dynastic States and Empires: A Global Perspective, edited by Jeroen Duindam, Tülay Artan, and Metin Kunt, 145-170. Leiden: Brill, 2011.

- Charlemagne: The Formation of a European Identity. Cambridge: Cambridge University Press, 2008.

—_. "The Carolingian Renaissance of Culture and Learning." In Charlemagne: Empire and Society, edited by Joanna Story, 151-182. Manchester: Manchester University Press, 2005.

- The Frankish Kingdoms under the Carolingians: 751-987. London: Longman, 1983.

McLeod, Shane. "Feeding the micel here in England, c. 865-878." Journal of the Australian Early Medieval Association 2 (2006): 141-156.

- The Beginning of Scandinavian Settlement in England: The Viking "Great Army" and Early Settlers, c. 865-900. Turnhout: Brepols, 2014.

Meens, Rob. "The Frequency and Nature of Early Medieval Penance." In Handling Sin: Confession in the Middle Ages, edited by Peter Biller and A.J. Minnis, 35-62. York: York Medieval Press, 1998.

Melleno, Daniel. "North Sea Networks: Trade and Communication from the Seventh to the Tenth Century." Comitatus 45 (2014): 65-89.

Metcalf, D.M. "Viking-Age Numismatics 2: Coinage in the Northern Lands in Merovingian and Carolingian Times." Numismatic Chronicle 156 (1996): 399-428.

Metz, Wolfgang. Das karolingische Reichsgut. Berlin: de Gruyter, 1960.

Middleton, Neil. "Early Medieval Port Customs, Tolls and Controls on Foreign Trade." Early Medieval Europe 13, no. 4 (2005): 313-358.

Moerman, H.J. Nederlandse plaatsnamen: een overzicht. Leiden: Brill, 1956.

Mohr,Andreas. Das Wissen über die Anderen: zur Darstellung fremder Völker in den fränkischen Quellen der Karolingerzeit. Münster: Waxmann, 2005.

Morden , Lesley Anne. "How Much Material Damage Did the Northmen Actually Do to Ninth-Century Europe?” PhD Diss., Simon Fraser University, 2007.

Musset, Lucien. Les invasions: le second assaut contre l'Europe chrétienne (VII ${ }^{e}-X I^{e}$ siècles). 2nd ed. Paris: Presses Universitaires de France, 1971.

Myhre, Bjørn. "The Beginning of the Viking Age: Some Current Archaeological Problems." In Viking Revaluations, edited by Anthony Faulkes and Richard Perkins, 182-204. London: Viking Society for Northern Research, 1993.

_. "The Early Viking Age in Norway." Acta Archaeologica 71 (2000): 35-47. 
_. "The Iron Age." In The Cambridge History of Scandinavia, edited by Knut Helle, I:60-93. Cambridge: Cambridge University Press, 2003.

Naismith, Rory. "Islamic Coins from Early Medieval England." Numismatic Chronicle 165 (2005): 193-222.

Näsman, Ulf. "Comments on Inger Storli: 'Court Sites of Arctic Norway.'” Norwegian Archaeological Review 44, no. 1 (2011): 89-117.

."Exchange and Politics: The Eighth-Early Ninth Century in Denmark." In The Long Eighth Century: Production, Distribution and Demand, edited by Inge Lyse Hansen and Chris Wickham, 35-68. Leiden: Brill, 2000.

. "Raids, Migrations, and Kingdoms - the Danish Case." Acta Archaeologica 71 (2000): 1-7.

."The Ethnogenesis of the Danes and the Making of a Danish Kingdom." AngloSaxon Studies in Archaeology and History 10 (1999): 1-10.

. "The Justinianic Era of South Scandinavia: An Archaeological View." In The Sixth Century: Production, Distribution and Demand, edited by Richard Hodges and William Bowden, 255-278. Leiden: Brill, 1998.

—_. "Vendel Period Glass from Eketorp-II, Öland, Sweden." Acta Archaeologica 55 (1984): 55-116.

Nelson, Janet. Charles the Bald. London: Longman, 1992.

. "Dispute Settlement in Carolingian West Francia." In The Settlement of Disputes in Early Medieval Europe, edited by Wendy Davies and Paul Fouracre, 45-64. Cambridge: Cambridge University Press, 1986.

_. "England and the Continent in the Ninth Century: II,TheVikings and Others." Transactions of the Royal Historical Society 13 (2003): 1-28.

-."Kingship and Empire in the CarolingianWorld."'In Carolingian Culture:Emulation and Innovation, edited by Rosamund McKitterick, 52-87. Cambridge: Cambridge University Press, 1994.

_. "Kingship and Royal Government." In The New Cambridge Medieval History, edited by Rosamond McKitterick, II:383-430. Cambridge: Cambridge University Press, 1995.

- "Making Ends Meet: Wealth and Poverty in the Carolingian Church." In The Frankish World, 750-900, 145-153. London: Hambledon, 1996.

-. "The Church's Military Service in the Ninth Century: A Contemporary Comparative View?” Studies in Church History 20, no. 1 (1983): 15-30.

—. "The Frankish Empire." In The Oxford Illustrated History of the Vikings, edited by Peter Sawyer, 19-47. Oxford: Oxford University Press, 1997.

—. "The Frankish Kingdoms, 814-898: The West." In The New Cambridge Medieval History, edited by Rosamond McKitterick, II:110-141. Cambridge: Cambridge University Press, 1995.

. The Frankish World: 750-900. London: Hambledon, 1996.

Nicholas, David. The Growth of the Medieval City: From Late Antiquity to the Early Fourteenth Century. London: Longman, 1997.

Nicolardot, Jean-Pierre, and Phlippe Guigon. "Une forteresse du X $\mathrm{X}^{\mathrm{e}}$ siècle: le camp de Péran à Plédran (Côtes d'Armor)." Revue archéologique de l'Ouest 8 (1991): 123-157.

Nielsen, Svend. "Urban Economy in Southern Scandinavia in the Second Half of the First Millennium AD." In The Scandinavians: From the Vendel Period to the Tenth Century, edited by Judith Jesch, 177-197. Woodbridge: Boydell, 2002. 
Niermeyer, J.F., and C. van de Kieft. Mediae Latinitatis lexicon minus. Leiden: Brill, 1976.

Nilles, Richard. "Marmoutier (Bas-Rhine): abbatiale Saint-Pierre et Saint-Paul." Archéologie médiévale 30-31 (2001): 409.

Nissen-Jaubert, Anne. "Some Aspects of Viking Research in France." Acta Archaeologica 71 (2000): 159-169.

Noble, Thomas. "The Revolt of King Bernard of Italy in 817: Its Causes and Consequences." Studi Medievali: Serie Terza 15, no. 1 (1974): 315-326.

Noizet, Hélène. "Les chanoines de Saint-Martin de Tours et les Vikings." In Les fondations scandinaves en Occident et les débuts du duché de Normandie, edited by Pierre Bauduin, 53-66. Caen: CRAHM, 2005.

Noonan, Thomas S. “European Russia, c. 500-c. 1050.” In The New Cambridge Medieval History, edited by Timothy Reuter, III:485-513. Cambridge: Cambridge University Press, 2000.

— "The Vikings in the East: Coins and Commerce." In Developments around the Baltic and the North Sea in the Viking Age, edited by Björn Ambrosiani and Helen Clarke, 215-236. Stockholm: Riksantikvarieämbetet, 1994.

Ó Cróinín, Dáibhí. Early Medieval Ireland 400-1200. London: Longman, 1995.

Ober, Josiah. "Models and Paradigms in Ancient History." The Ancient History Bulletin 3, no. 6 (1989): 134-137.

Ohler, Norbert. The Medieval Traveller. Translated by Caroline Hillier. Woodbridge: Boydell, 1989.

Olausson, Michael. "Fortified Manors in the Migration Period in the Eastern Part of Central Sweden - A Discussion of Politics, Warfare and Architecture." In Military Aspects of Scandinavian Society in a European Perspective AD 1-1300, edited by Anne Nørgård Jørgensen and Birthe L. Clausen, 157-168. Copenhagen: National Museum of Denmark, 1997.

Ørsnes, Mogens. "Südskandinavische Ornamentik in der jüngeren Germanischen Eisenzeit." Acta Archaeologica 40 (1969): 1-121.

Otte, Marcel. "L'archéologie de la Place Saint-Lambert à Liège." In L'archéologie en région wallonne 1980-1990, edited by J. Barlet and J. Barthélémy, 93-97. Commission Royale de Monuments, Sites et Fouilles, 1993.

Oudhof, J.W.M., A.A.A. Verhoeven, and I. Schuuring. Tiel rond 1000: analyse van vier opgravingen in de Tielse binnenstad. Amsterdam: Amsterdam University Press, 2013.

Owen, Olwyn. "The Scar Boat Burial - and the Missing Decades of the Early Viking Age in Orkney and Shetland." In Scandinavia and Europe 800-1350: Contact, Conflict, and Coexistence, edited by Jonathan Adams and Katherine Holman, 3-33. Turnhout: Brepols, 2004.

Päffgen, Bernd. "Urban Settlements and Sacral Topography in the Rhineland at the Time of the Viking Raids." In Vikings on the Rhine: Recent Research on Early Medieval Relations between the Rhinelands and Scandinavia, edited by Rudolf Simek and Ulrike Engel, 83-109.Vienna: Fassbaender, 2004.

Pedersen, Unn. "Urban Craftspeople at Viking-Age Kaupang." In Everyday Products in the Middle Ages: Crafts, Consumption and the Individual in Northern Europe c. AD 800-1600, edited by Gitte Hansen, Steven Ashby, and Irene Baug, 51-68. Oxford: Oxbow, 2015.

Pentz, Peter. “Ships \& theVikings.” In Vikings: Life and Legend, edited by Gareth Williams, Peter Pentz, and Matthias Wemhoff, 202-227. London: British Museum Press, 2014.

Pérennec, Ronan, and Annie Bardel. "Landévennec: un monastère carolingien à la pointe de la Bretagne." In Landévennec: les Vikings et la Bretagne, edited by Magali Coumert and Yvon Tranvouez, 21-59. Brest: Université de Bretagne Occidentale, 2015. 
Périn, Patrick. "Les objets vikings du musée des antiquités de la Seine-Maritime, à Rouen." Cahier des Annales de Normandie 23 (1990): 161-188.

Pilø, Lars. "The Pottery." In Things from the Town: Artefacts and Inhabitants in Viking-Age Kaupang, edited by Dagfinn Skre, 281-304. Aarhus: Aarhus University Press, 2011.

_. "The Settlement: Character, Structures and Features." In Kaupang in Skiringssal, edited by Dagfinn Skre, 191-222. Aarhus: Aarhus University Press, 2007.

Pirenne, Henri. “Mahomet et Charlemagne." Revue belge de philologie et d'histoire 1, no. 1 (1922): 77-86.

Price, Neil. "Pirates of the North Sea? TheViking Ship as Political Space." In Comparative Perspectives on Past Colonisation, Maritime Interaction and Cultural Integration, edited by Lene Melheim, Håkon Glørstad, and Zanette Tsigaridas Glørstad, 149-176. Sheffield: Equinox, 2016.

_- "Ship-Men and Slaughter-Wolves: Pirate Polities in the Viking Age." In Persistent Piracy: Maritime Violence and State-Formation in Global Historical Perspective, edited by Stefan Eklöf Amirell and Leos Müller, 51-68. London: Macmillan, 2014.

- The Vikings in Brittany. London: Viking Society for Northern Research, 1989.

_ . "Viking Brittany: Revisiting the Colony that Failed." In Early Medieval Art and Archaeology in the Northern World, edited by Andrew Reynolds and Leslie Webster, 731-742. Leiden: Brill, 2013.

Price, T. Douglas. Ancient Scandinavia: An Archaeological History from the First Humans to the Vikings. Oxford: Oxford University Press, 2015.

Prié, Arnaud. "Paris (Seine). 15, Rue du Temple (III ${ }^{\mathrm{e}}$ Arr.)." Archéologie médiévale 28 (1999): 283-284.

Racinet, Philippe. "Une résidence carolingienne sur 'motte' (avant le dernier quart du $\mathrm{X}^{\mathrm{e}}$ siècle): phases $2 \mathrm{~A}$ et $2 \mathrm{~B}$.” In Le site castral et prioral de Boves du Xe au XVII siècle, 27-43. Revue Archéologique de Picardie, Numéro spécial 20. Senlis, 2002.

Radtke, Christian. "Money, Port and Ships from a Schleswig Point of View." In Connected by the Sea: Proceedings of the Tenth International Symposium on Boat and Ship Archaeology, Roskilde 2003, edited by Lucy Blue, Fred Hocker, and Anton Englert, 147-151. Oxford: Oxbow, 2006.

Raffield, Ben. "Bands of Brothers: A Re-Appraisal of the Viking Great Army and its Implications for the Scandinavian Colonization of England." Early Medieval Europe 24, no. 3 (2016): 308-337.

Raffield, Ben, Claire Greenlow, Neil Price, and Mark Collard. "Ingroup Identification, Identity Fusion and the Formation of Viking War Bands." World Archaeology 48, no. 1 (2016): 35-50.

Renaud, Jean. "La toponymie normanique: reflet d'une colonisation." In La progression des Vikings, des raids à la colonisation, edited by Anne-Marie Flambard Héricher, 189205. Rouen: Université de Rouen, 2003.

L Les Îles de Vendée face aux Vikings. Verrières: l'Etrave, 2008.

Les Vikings en France. Rennes: Ouest-France, 2000.

Les Vikings et la Normandie. Rennes: Ouest-France, 1989.

. Vikings et noms de lieux de Normandie: dictionnaire des toponymes d'origine scandinave en Normandie. Cully: OREP, 2009.

Renoux, Annie. "Karolingische Pfalzen in Nordfrankreich (751-987).” In 799 - Kunst und Kultur der Karolingerzeit, edited by Christoph Stiegemann and Matthias Wemhoff, III:130-137. Mainz: von Zabern, 1999. 
Reuter, Timothy. "Introduction: Reading the Tenth Century." In The New Cambridge Medieval History, edited by Timothy Reuter, III:1-24. Cambridge: Cambridge University Press, 2000.

- "Plunder and Tribute in the Carolingian Empire." Transactions of the Royal Historical Society 35 (1985): 75-94.

_. "The End of Carolingian Military Expansion." In Medieval Polities and Modern Mentalities, edited by Janet L. Nelson, 251-267. Cambridge: Cambridge University Press, 2006.

—. "'You Can't Take It with You': Testaments, Hoards, and Moveable Wealth in Europe, 600-1100.” In Treasure in the Medieval West, edited by Elizabeth Tyler, 11-24. York: York Medieval Press, 2000.

Reynolds, Susan. Fiefs and Vassals: The Medieval Evidence Reinterpreted. Oxford: Oxford University Press, 1994.

Richards, Julian. Viking Age England. 2nd ed. Stroud: Tempus, 2000.

Richards, Julian, P. Beswick, J. Bond, M. Jecock, J. McKinley, S. Rowland, and F. Worley. "Excavations at the Viking Barrow Cemetery at Heath Wood, Ingleby, Derbyshire." The Antiquaries Journal 84 (2004): 23-116.

Riché, Pierre. Daily Life in the World of Charlemagne. Liverpool: Liverpool University Press, 1973.

- The Carolingians: A Family Who Forged Europe. Philadelphia: University of Pennsylvania Press, 1993.

Ridel, Élisabeth. "From Scotland to Normandy: The Celtic Sea Route of the Vikings." In West over Sea: Studies in Scandinavian Sea-Borne Expansion and Settlement before 1300, edited by Beverly Ballin Smith, Simon Taylor, and Gareth Williams, 81-94. Leiden: Brill, 2007.

_- "Sur la route des Vikings: les îles anglo-normandes entre Bretagne et Normandie." In Landévennec: les Vikings et la Bretagne, edited by Magali Coumert and Yvon Tranvouez, 127-155. Brest: Université de Bretagne Occidentale, 2015.

- ed. "Corpus des objets vikings découverts en France." In Les Vikings dans l'empire franc, 130-135. Bayeux: OREP, 2014.

Rieck, Flemming. "Aspects of Coastal Defence in Denmark." In Aspects of Maritime Scandinavia AD 200-1200, edited by Ole Crumlin-Pedersen, 83-96. Roskilde: Viking Ship Museum, 1991.

Rimmer, Peter. "A Conceptual Framework for Examining Urban and Regional Transport Needs in South-East Asia.” Pacific Viewpoint 18, no. 2 (1977): 133-148.

Ringtved, Jytte. "The Geography of Power: South Scandinavia before the Danish Kingdom." Anglo-Saxon Studies in Archaeology and History 10 (1999): 49-63.

Rio, Alice. Slavery after Rome: 500-1100. Oxford: Oxford University Press, 2017.

Rodrigue, Jean-Paul. The Geography of Transport Systems. 4th ed. New York: Routledge, 2017.

Roesdahl, Else. "What May We Expect? On the Problem of Vikings and Archaeology in Normandy." In La progression des Vikings, des raids à la colonisation, edited by AnneMarie Flambard Héricher, 207-213. Rouen: Université de Rouen, 2003.

Ros, Jonas. "Sigtuna." In The Viking World, edited by Stefan Brink and Neil Price, 140144. London: Routledge, 2008.

Roslund, Mats. Guests in the House: Cultural Transmission between Slavs and Scandinavians 900 to 1300 AD. Leiden: Brill, 2007.

Rouche, Michel. "The Vikings versus the Towns of Northern Gaul: Challenge and Response." In Medieval Archaeology, edited by Charles Redman, 41-56. Binghamton: Center for Medieval and Early Renaissance Studies, 1989. 
Saint-Jean Vitus, Benjamin. "Tournus du castrum antique au bourg médiéval: paysage monastique et développement urbain.” In Saint-Philibert de Tournus: histoire, archéologie, art, edited by Jacques Thirion, 383-396. Tournus: Centre International d'Etudes Romanes, 1995.

Salin, Édouard. "Les tombes gallo-romaines et mérovingiennes de la basilique de SaintDenis (Fouilles de Janvier-Février 1957)." Mémoires de l'institut national de France 44, no. 1 (1960): 169-264.

Samson, Ross. "The Residences of Potentiores in Gaul and Germania in the Fifth to Mid-Ninth Centuries.” PhD Diss., University of Glasgow, 1991.

Sanmark, Alexandra." Power and Conversion: A Comparative Study of Christianization in Scandinavia.” PhD Diss., Uppsala University, 2004.

Sawyer,Birgit, and Peter Sawyer."'Scandinavia Enters Christian Europe.” In The Cambridge History of Scandinavia, edited by Knut Helle, I:147-159. Cambridge: Cambridge University Press, 2003.

Sawyer, Peter. Kings and Vikings: Scandinavia and Europe AD 700-1100. Abingdon: Routledge, 1984.

- The Age of the Vikings. 2nd ed. London: Edward Arnold, 1971.

" "The Viking Expansion." In The Cambridge History of Scandinavia, edited by Knut Helle, I:105-120. Cambridge: Cambridge University Press, 2003.

. "The Viking Legacy." In The Oxford Illustrated History of the Vikings, edited by Peter Sawyer, 250-261. Oxford: Oxford University Press, 1997.

Schmitz, Gerhard. "Kapitularien.” In Handwörterbuch zur deutschen Rechtsgeschichte, edited by Albrecht Cordes, Heiner Lück, and Dieter Werkmüller, II: cols. 1604-1612. Berlin: Schmidt, 2012.

Screen, Elina. "The Importance of the Emperor: Lothar I and the Frankish Civil War, 840-843." Early Medieval Europe 12, no. 1 (2003): 25-51.

Searle, Eleanor. Predatory Kinship and the Creation of Norman Power, 840-1066. Berkeley: University of California Press, 1988.

Seegrün, Wolfgang. Das Erzbistum Hamburg in seinen älteren Papsturkunden. Cologne: Böhlau, 1976.

Segschneider, Martin. "Trade and Centrality between the Rhine and the Limfjord around 500 AD: The Beachmarket on the Northfrisian Island Amrum and its Context." In Central Places in the Migration and the Merovingian Periods, edited by Birgitta Hårdh and Lars Larsson, 247-256. Stockholm: Almqvist \& Wiksell, 2002.

Sheehan, John. "The Longphort in Viking Age Ireland." Acta Archaeologica 79 (2008): 282-295.

Sherratt, Andrew. "What Can Archaeologists Learn from Annalistes?" In Archaeology, Annales, and Ethnohistory, edited by A. Bernard Knapp, 135-143. Cambridge: Cambridge University Press, 1992.

Siegmund, Frank. "Merovingian Beads on the Lower Rhine." Beads 7 (1995): 37-53.

Simek, Rudolf. "The Emergence of the Viking Age: Reasons and Triggers." In Vikings on the Rhine: Recent Research on Early Medieval Relations between the Rhinelands and Scandinavia, edited by Rudolf Simek and Ulrike Engel, 9-21. Vienna: Fassbaender, 2004.

Sindbæk, Søren. "Broken Links and Black Boxes: Material Affiliations and Contextual Network Synthesis in the Viking World." In Network Analysis in Archaeology: New Approaches to Regional Interaction, edited by Carl Knappett, 71-94. Oxford: Oxford University Press, 2013.

_. "Local and Long-Distance Exchange." In The Viking World, edited by Stefan Brink and Neil Price, 150-158. London: Routledge, 2008. 
"Networks and Nodal Points: The Emergence of Towns in Early Viking Age Scandinavia." Antiquity 81 (2007): 119-132.

."Silver Economies and Social Ties: Long-Distance Interaction, Long-Term

Investments - and Why the Viking Age Happened." In Silver Economies, Monetisation and Society in Scandinavia, AD 800-1100, edited by James Graham-Campbell, Søren Sindbæk, and Gareth Williams, 41-65. Aarhus: Aarhus University Press, 2011.

—. "The Lands of Denemearce: Cultural Differences and Social Networks of the Viking Age in South Scandinavia." Viking and Medieval Scandinavia 4 (2008): 169-208. Skovgaard-Petersen, Inge. "The Making of the Danish Kingdom." In The Cambridge

History of Scandinavia, edited by Knut Helle, I:168-183. Cambridge: Cambridge University Press, 2003.

Skre, Dagfinn. "Commodity Money, Silver and Coinage in Viking-Age Scandinavia." In Silver Economies, Monetisation and Society in Scandinavia, AD 800-1100, edited by James Graham-Campbell, Søren Sindbæk, and Gareth Williams, 67-91. Aarhus: Aarhus University Press, 2011.

— . "Dark Age Towns: The Kaupang Case - Reply to Przemysław Urbańczyk." Norwegian Archaeological Review 41, no. 2 (2008): 194-212.

—. "Dealing with Silver: Economic Agency in South-Western Scandinavia AD 600-1000." In Means of Exchange: Dealing with Silver in the Viking Age, edited by Dagfinn Skre, 343-355. Aarhus: Aarhus University Press, 2007.

- "Markets, Towns and Currencies in Scandinavia ca. AD 200-1000." In From

One Sea to Another: Trading Places in the European and Mediterranean Early Middle Ages, edited by Sauro Gelichi and Richard Hodges, 47-63. Turnhout: Brepols, 2012.

_- "Money and Trade in Viking-Age Scandinavia." In Economies, Monetisation and

Society in the West Slavic Lands 800-1200 AD, edited by Mateusz Bogucki and Marian Rębkowski, 75-87. Szczecin: Szczecin University, 2013.

- "Post-Substantivist Towns and Trade AD 600-1000." In Means of Exchange:

Dealing with Silver in the Viking Age, edited by Dagfinn Skre, 327-341. Aarhus: Aarhus University Press, 2007.

—. "The Development of Urbanism in Scandinavia." In The Viking World, edited by Stefan Brink and Neil Price, 83-92. London: Routledge, 2008.

- "The Inhabitants: Origins and Trading Connexions." In Things from the

Town: Artefacts and Inhabitants in Viking-Age Kaupang, edited by Dagfinn Skre, 417-441. Aarhus: Aarhus University Press, 2011.

—_. "The Warrior Manor." In Avaldsnes: A Sea-Kings' Manor in First-Millennium Western Scandinavia, edited by Dagfinn Skre, 765-779. Berlin: de Gruyter, 2018.

Smith, Beverley Ballin. "Norwick: Shetland's First Viking Settlement?" In West over Sea: Studies in Scandinavian Sea-Borne Expansion and Settlement before 1300, edited by Beverly Ballin Smith, Simon Taylor, and Gareth Williams, 287-297. Leiden: Brill, 2007.

Smith, Julia. Province and Empire: Brittany and the Carolingians. Cambridge: Cambridge University Press, 1992.

Smyth, Alfred P. Scandinavian Kings in the British Isles: 850-880. Oxford: Oxford University Press, 1977.

Société des antiquaires de Normandie. Mémoires de la Société des antiquaires de Normandie. Vol. IX. Caen: Hardel, 1835.

Solberg, Bergljot. "Weapon Export from the Continent to the Nordic Countries in the Carolingian Period.” Studien zur Sachsenforschung 7 (1991): 241-259. 
Somerville, Angus, and R. Andrew McDonald. The Vikings and Their Age. Toronto: University of Toronto Press, 2013.

Soulat, Jean. "Le port de Taillebourg - Port d'Envaux et les contacts avec le Nord-Ouest de l'Europe." In Archéologie et histoire du fleuve Charente: Taillebourg-Port d'Envaux, edited by Annie Dumont and Jean-François Mariotti, 249-262. Dijon: Éditions Universitaires, 2013.

Stalsberg, Anne. "Herstellung und Verbreitung der Vlfberht-Schwertklingen. Eine Neubewertung." Zeitschrift für Archäologie des Mittelalters 36 (2008): 89-118.

Stenton, Frank. Anglo-Saxon England. 3rd ed. Oxford: Oxford University Press, 1971.

Steppuhn, Peter. Die Glasfunde von Haithabu. Neumünster: Wachholtz, 1998.

Steuer, Heiko. "Der Handel derWikingerzeit zwischen Nord- und Westeuropa aufgrund archäologischer Zeugnisse." In Untersuchungen zu Handel und Verkehr der vor- und frühgeschichtlichen Zeit in Mittel- und Nordeuropa, edited by Klaus Düwel, 113-197. Göttingen: Vandenhoeck \& Ruprecht, 1987.

Stone, Rachel. Morality and Masculinity in the Carolingian Empire. Cambridge: Cambridge University Press, 2011.

Tarrou, Liliane. "Les Vikings en Bretagne et en Loire-Atlantique à la lumière des vestiges matériels." In Les Vikings dans l'empire franc, edited by Élisabeth Ridel, 34-39. Bayeux: OREP, 2014.

Ten Harkel, Letty. "A Viking Age Landscape of Defence in the Low Countries? The Ringwalburgen in the Dutch Province of Zeeland.” In Landscapes of Defence in Early Medieval Europe, edited by John Baker, Stuart Brookes, and Andrew Reynolds, 223259. Turnhout: Brepols, 2013.

Tereygeol, Florian. "Production and Circulation of Silver and Secondary Products (Lead and Glass) from Frankish Royal Silver Mines at Melle (Eighth to Tenth Century)." In Post-Roman Towns, Trade and Settlement in Europe and Byzantium: The Heirs of the Roman West, edited by Joachim Henning, 123-134. Berlin: de Gruyter, 2007.

Thomas, Gabor. "Carolingian Culture in the North Sea World: Rethinking the Cultural Dynamics of Personal Adornment in Viking-Age England." European Journal of Archaeology 15, no. 3 (2012): 486-518.

Thurston, Tina L. Landscapes of Power, Landscapes of Conflict: State Formation in the South Scandinavian Iron Age. New York: Kluwer, 2002.

Tilley, Christopher. An Ethnography of the Neolithic: Early Prehistoric Societies in Southern Scandinavia. Cambridge: Cambridge University Press, 2003.

Tolan, John. Saracens: Islam in the Medieval European Imagination. New York: Columbia University Press, 2002.

Tulp, Caroline. "Tjitsma, Wijnaldum: An Early Medieval Production Site in the Netherlands." In Markets in Early Medieval Europe: Trading and "Productive" Sites, 650850, edited by Tim Pestell and Katharina Ulmschneider. Macclesfield: Windgather Press, 2003.

Tummuscheit, Astrid, and Frauke Witte. "The Danevirke in the Light of Recent Excavations." In The Fortified Viking Age, edited by Jesper Hansen and Mette Bruus, 69-74. Odense: University Press of Southern Denmark, 2018.

Tys, Dries, Pieterjan Deckers, and Barbora Wouters. "Circular, D-Shaped and Other Fortifications in 9th- and 10th-Century Flanders and Zeeland as Markers of the Territorialisation of Power(s).”'In Fortified Settlements in Early Medieval Europe: Defended Communities of the 8th-10th Centuries, edited by Neil Christie and Hajnalka Herold, 175-191. Oxford: Oxbow, 2016. 
Valante, Mary. "Castrating Monks: Vikings, Slave Trade, and the Value of Eunuchs." In Castration and Culture in the Middle Ages, edited by Larissa Tracy, 174-187. Woodbridge: Boydell \& Brewer, 2013.

- The Vikings in Ireland. Dublin: Four Courts, 2008.

Van Dierendonck, R.M. "The Early Medieval Circular Fortresses in the Province of Zeeland, The Netherlands: Ten Years After.” In Ringwälle und verwandte Strukturen des ersten Jahrtausends n. Chr. an Nord- und Ostsee, edited by Martin Segschneider, 249274. Neumünster: Wachholtz, 2009.

Van Es,W.A. “Dorestad Centred.” In Medieval Archaeology in the Netherlands, edited by Jan Besteman, J.M. Bos, and H.A. Heidinga, 151-182. Maastricht: Van Gorcum, 1990.

Van Es, W.A., and W.J.H. Verwers. Excavations at Dorestad III: Hoogstraat 0, II-IV. Amersfoort: RACM, 2009.

- Excavations at Dorestad IV: The Settlement on the River Bank Area. Amersfoort: Cultural Heritage Agency, 2015.

Van Vliet, Kaj. "Traiecti Muros Heu: The Bishop of Utrecht during and after the Viking Invasions of Frisia (834-925)." In Vikings on the Rhine: Recent Research on Early Medieval Relations between the Rhinelands and Scandinavia, edited by Rudolf Simek and Ulrike Engel, 133-154.Vienna: Fassbaender, 2004.

Vance, James E. The Merchant's World: The Geography of Wholesaling. London: Prentice-Hall, 1970.

Venault, Stéphane. "Auxerre (Yonne): le site des archives départementales." Archéologie médiévale 28 (1999): 214.

Vercauteren, F. “Comment s'est-on défendu, au IX siècle dans l'empire franc contre les invasions normandes?" In Annales du XXX congrès de la fédération archéologique et historique de Belgique, 117-132. Brussels: La Fédération, 1936.

Verhaeghe, Frans. "Continuity and Change: Links between Medieval Towns and the Roman Substratum in Belgium." Studia varia Bruxellensia 2 (1990): 229-253.

—. "Urban Developments in the Age of Charlemagne." In Charlemagne: Empire and Society, edited by Joanna Story, 259-287. Manchester: Manchester University Press, 2005.

Verhoeven, A.A.A. "Verspreidingsgebieden van aardewerk in de vroege en volle middeleeuwen." In Rotterdam Papers, edited by A. Carmiggelt, 7:75-84. Rotterdam: ROB, 1992.

Verhulst, Adriaan. "Economic Organisation." In The New Cambridge Medieval History, edited by Rosamond McKitterick, II:481-509. Cambridge: Cambridge University Press, 1995.

- The Carolingian Economy. Cambridge: Cambridge University Press, 2002.

. The Rise of Cities in North-West Europe. Cambridge: Cambridge University Press, 1999.

Verkerk, C.L. "Het tolsysteem in het mondingsgebied van Rijn, Maas en Schelde tot de elfde eeuw." In Rotterdam Papers, edited by A. Carmiggelt, 7:39-49. Rotterdam: ROB, 1992.

Vlierman, Karel."Scheeps- en stadsarcheologie: de betekenis van scheeps(hout)vondsten in Nederlandse middeleeuwse steden." In Middeleeuwse toestanden: archeologie, geschiedenis en monumentenzorg, edited by P.J. Woltering, W.J.H. Verwers, and G.H. Scheepstra, 119-148. Hilversum: Verloren, 2002.

Vogel, Walther. Die Normannen und das fränkische Reich bis zur Gründung der Normandie (799-911). Heidelberg: Winter, 1906. 
Wagner, Åse Kari H. "Les noms de lieux issus de l'implantation scandinave en Normandie: le cas des noms en -tuit." In Les fondations scandinaves en Occident et les débuts du duché de Normandie, edited by Pierre Bauduin, 241-252. Caen: CRAHM, 2005.

Wallace-Hadrill, J.M. The Vikings in Francia. Stenton Lecture. Reading: University of Reading, 1975.

Walsh, Christine. "Baptized but not Converted: The Vikings in Tenth-Century Francia." Studies in Church History 51 (2015): 67-79.

Wamers, Egon. "Continental and Insular Metalwork." In Things from the Town: Artefacts and Inhabitants in Viking-Age Kaupang, edited by Dagfinn Skre, 65-97. Aarhus: Aarhus University Press, 2011.

Webber, Nick. The Evolution of Norman Identity, 911-1154. Woodbridge: Boydell, 2005.

Werner, Karl Ferdinand. "Hludovicus Augustus: gouverner l'empire chrétien - idées et réalités.” In Charlemagne's Heir: New Perspectives on the Reign of Louis the Pious (814840), edited by Peter Godman and Roger Collins, 3-123. Oxford: Clarendon, 1990.

. "Missus, Marchio, Comes: entre l'Administration centrale et l'administration locale de l'empire carolingien." In Histoire comparée de l'administration (IV ${ }^{e}-X V I I I^{e}$ siècles), edited by W. Paravicini and K.F.Werner, 191-239. Munich: Artemis, 1980.

Westerdahl, Christer. "From Land to Sea, From Sea to Land: On Transport Zones, Borders and Human Space." In Down the River to the Sea, edited by Jerzy Litwin, 11-20. Gdańsk: Polish Maritime Museum, 2000.

Wickham, Chris. Framing the Early Middle Ages. Oxford: Oxford University Press, 2005.

Wienberg,Jes."Vikings and the Western Frontier." In Small Things - Wide Horizons: Studies in Honour of Birgitta Hårdh, edited by Lars Larsson, Fredrik Ekengren, Bertil Helgesson, and Bengt Söderberg, 289-294. Oxford: Archaeopress, 2015.

Willemsen, Annemarieke. "Dorestad as a Fluviatile Society." In Maritime Societies of the Viking and Medieval World, edited by James H. Barrett and Sarah Jane Gibbon, 108121. Leeds: Maney, 2016.

—_. "Scattered across the Waterside: Viking Finds from the Netherlands." In Vikings on the Rhine: Recent Research on Early Medieval Relations between the Rhinelands and Scandinavia, edited by Rudolf Simek and Ulrike Engel, 65-82. Vienna: Fassbaender, 2004.

Williams, Alan. The Sword and the Crucible: A History of the Metallurgy of European Swords up to the 16th Century. Leiden: Brill, 2012.

Williams, Gareth. "Kingship, Christianity and Coinage: Monetary and Political Perspectives on Silver Economy in the Viking Age." In Silver Economy in the Viking Age, edited by James Graham-Campbell and Gareth Williams, 177-214. Walnut Creek: Left Coast Press, 2007.

_ . "Raiding and Warfare." In The Viking World, edited by Stefan Brink and Neil Price, 193-203. London: Routledge, 2008.

. "Viking Camps and the Means of Exchange in Britain and Ireland in the Ninth Century." In The Vikings in Ireland and Beyond: Before and After the Battle of Clontarf, edited by Howard Clarke and Ruth Johnson, 93-116. Dublin: Four Courts, 2015.

Winroth, Anders. The Age of the Vikings. Princeton: Princeton University Press, 2014. . The Conversion of Scandinavia: Vikings, Merchants, and Missionaries in the Remaking of Northern Europe. New Haven: Yale University Press, 2012. 


\section{Bibliography}

Wormald, C. Patrick. "Viking Studies: Whence and Whither?” In The Vikings, edited by R.T. Farrell, 128-153. London: Phillimore, 1982.

Wormald, Patrick. Legal Culture in the Early Medieval West. London: Hambledon, 1999.

Wyss, Michaël. "Un établissement carolingien mis au jour à proximité de l'abbaye de Saint-Denis: la question du palais de Charlemagne." In "Aux marches du Palais". Qu'est-ce qu'un palais médiéval?, edited by Annie Renoux, 191-200. Caen: Société d'Archéologie médiévale, 2001.

Yorke, Barbara. Kings and Kingdoms of Early Anglo-Saxon England. London: Seaby, 1990. Zadora-Rio, Élisabeth, and Henri Galinié. "Rigny-Ussé (Indre-et-Loire): Rigny." Archéologie médiévale 30-31 (2001): 226-227.

Zimmermann, Michel. "Western Francia: The Southern Principalities." In The New Cambridge Medieval History, edited by Timothy Reuter, III:420-455. Cambridge: Cambridge University Press, 2000. 